PNL-6724

UC-510

31

\title{
Evaluation of the Mixing System for the West Valley Melter Feed Hold Tank
}
C. L. Fow
D. E. Kurath
B. A. Pulsipher

January 1989

Prepared for the U.S. Department of Energy under Contract DE-AC06-76RLO 1830

Pacific Northwest Laboratory Operated for the U.S. Department of Energy by Battelle Memorial Institute 


\title{
DISCLAIMER
}

This report was prepared as an account of work sponsored by an agency of the United States Government. Neither the United States Government nor any agency thereof, nor Battelle Memorial Institute, nor any or their employees, makes any warranty, expressed or implied, or assumes any legal liability or responsibility for the accuracy, completeness, or usefulness of any information, apparatus, product, or process disclosed, or represents that its use would not infringe privately owned rights. Reference herein to any specific commercial product, process, or service by trade name, trademark, manufacturer, or otherwise does not necessarily constitute or imply its endorsement, recommendation, or favoring by the United States Government or any agency thereof, or Battelle Memorial Institute. The views and opinions of authors expressed herein do not necessarily state or reflect those of the United States Government or any agency thereof.

\author{
PACIFIC NORTHWEST LABORATORY \\ operated by \\ BATTELLE MEMORIAL INSTITUTE \\ for the \\ UNITED STATES DEPARTMENT OF ENERGY \\ under Contract DE-AC06-76RLO 1830
}

\author{
Printed in the United States of America \\ Available from \\ National Technical Information Service \\ United States Department of Commerce \\ 5285 Port Royal Road \\ Springfield, Virginia 22161 \\ NTIS Price Codes \\ Microfiche A01 \\ Printed Copy
}

$\begin{array}{cc}\text { Pages } & \begin{array}{c}\text { Price } \\ \text { Codes } \\ 001-025\end{array} \\ 026-050 & \text { A02 } \\ 051-075 & \text { A03 } \\ 076-100 & \text { A04 } \\ 101-125 & \text { A05 } \\ 126-150 & \text { A06 } \\ 151-175 & \text { A07 } \\ 176-200 & \text { A08 } \\ 201-225 & \text { A09 } \\ 226-250 & \text { A10 } \\ 251-275 & \text { A11 } \\ 276-300 & \text { A12 } \\ & \text { A13 }\end{array}$


EVALUATION OF THE MIXING SYSTEM FOR THE WEST VALLEY MELTER FEED HOLD TANK
C. L. Fow
D. E. Kurath
B. A. Pulsipher

January 1989

Prepared for

the U.S. Department of Energy

under Contract DE-ACO6-76RLO 1830

Pacific Northwest Laboratory

Richland, Washington 99352 


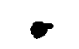

. 


\section{SUMMARY}

High-level radioactive liquid wastes are currently stored in underground tanks at several Department of Energy facilities. The current plan for management of these wastes is to convert them to a durable borosilicate glass, then isolate the glass in a deep geologic repository.

The process for converting the wastes to glass involves mixing the highlevel wastes with glass-forming chemicals, then transforming the resulting slurry into glass using a high-temperature furnace known as a slurry-fed ceramic melter. Maintaining the quality of the glass product and proficient melter operation depends on the ability of the waste slurry preparation and feed systems to produce and maintain a homogeneous mixture of waste and glass-former materials.

Pacific Northwest Laboratory (PNL) performed bench-scale tests in FY 1986 to provide a quantitative description of performance for several feed mixing systems in terms of measurable process variables (Peterson, McCarthy and Muhlstein 1986). One of the systems studied was the West Valley melter feed hold tank (MFHT). The bench-scale study used simulated West Valley melter feed to determine the full-scale parameters for sizing the agitator that is used to mix slurry in the MFHT.

Full-scale tests were performed in FY 1987 at West Valley using the MFHT. The objectives of these tests were as follows: 1) quantify the homogeneity of the melter feed slurry in the MFHT, 2) determine the representativeness of the slurry sample obtained by the liquid-sampling system for the MFHT, 3) determine the time required to resuspend and homogenize the melter feed slurry after a simulated unexpected power outage, and 4) verify the scale-up of the results from the bench-scale mixing study. This report discusses the results from the full-scale tests.

Two types of tests (homogeneity/sampling system tests and resuspension tests) were performed using three concentrations of simulated, nonradioactive melter feed slurry. The melter slurry concentrations tested included the reference melter feed, the reference melter feed concentrated to 75 v07\% (concentrated feed), and the reference melter feed diluted to 125 vol\% 
(dilute feed). The homogeneity/sampling system tests were performed to characterize the melter feed system and verify the bench-scale mixing data. The resuspension tests were performed to determine the time required to resuspend and uniformly mix the solids in the MFHT after a simulated, unexpected power outage.

For the homogeneity/sampling system tests, the homogeneity of the slurry was measured by comparing the average weight percent solids and the elemental concentrations of slurry samples taken from six sampling locations within the tank. The representativeness of the sampling system was determined by comparing the average weight percent solids and the elemental concentrations between the samples taken at six tank sampling locations and the sampling system. For the resuspension tests, the homogeneity of the tank was determined by comparing only weight percent solids of the slurry samples from within the tank.

The statistical design of the homogeneity/sampling system tests required 21 samples at each sampling location to attain a 95\% confidence level of detecting a difference of greater than 4.5 elemental weight percent. The statistical design of the resuspension tests required six samples at each sampling location. Samples were taken from the tank and analyzed for total solids and elemental concentrations in a random order. All analyses were conducted at West Valley.

Statistical data analyses were performed on as-analyzed and normalized values of the elemental concentrations. Results from these analyses are summarized in Table S.l. Four significant conclusions can be drawn from this data:

1) Analysis of normalized values can sometimes mask interactions. It can be deceptive when certain conditions affect some elements but not others, or affect all elemental constituents similarly. This can have significant impact during feed makeup.

2) The $15 \mathrm{Hp}$, single-speed (155 rpm) agitator installed in the MFHT produces a homogeneous mixture for the three concentrations of simulated melter feed slurry used in these tests. Slurries with significantly greater settling rates may produce different results. 
TABLE S.1. Results from Statistical Analysis of Elemental Concentration Data

\begin{tabular}{|c|c|c|c|}
\hline \multirow[b]{2}{*}{$\begin{array}{c}\text { Slurry } \\
\text { Concentration } \\
\end{array}$} & \multicolumn{3}{|c|}{ As-Analyzed Elemental Concentration } \\
\hline & $\begin{array}{c}\text { Sampler Bjas } \\
\text { Range (a) }\end{array}$ & $\begin{array}{l}\text { Tank Inhomogene jty } \\
\text { RSD }(b) \text { Range }(c)\end{array}$ & $\begin{array}{l}\text { Analytical } \\
\text { RSD Range (d) }\end{array}$ \\
\hline Concentrated & $0.3 \%-5.7 \%$ & $0.0 \%-1.3 \%$ & $1.4 \%-7.8 \%$ \\
\hline Reference & $0.4 \%-12.2 \%$ & $0.0 \%-0.0 \%$ & $2.4 \%-12.0 \%$ \\
\hline Dilute & $2.1 \%-29.2 \%$ & $0.0 \%-2.3 \%$ & $2.0 \%-20.7 \%$ \\
\hline & \multicolumn{3}{|c|}{ Normalized Elemental Concentration } \\
\hline Concentrated & $0.1 \%-1.7 \%$ & $0.0 \%-0.7 \%$ & $2.6 \%-5.3 \%$ \\
\hline Reference & $0.8 \%-6.9 \%$ & $0.0 \%-0.0 \%$ & $3.2 \%-9.6 \%$ \\
\hline Dilute & $0.2 \%-13.9 \%$ & $0.0 \%-0.8 \%$ & $4.2 \%-16.1 \%$ \\
\hline
\end{tabular}

(a) Sampler bias is the difference in elemental concentration between the average of the six tank sampling locations and the 1 iquid-sampling system.

(b) RSD is defined as relative standard deviation.

(c) Tank inhomogeneity range is the variability between the six sampling locations (see Figure 4.1).

(d) Analytical range is the variability in the analytical results for a particular sampling location.

3) The liquid-sampling system used in these tests obtains samples that are up to $2.6 \%$ higher in total solids, and are significantly different in certain elements. This may be because of the flow rate of the slurry in the sampling system and/or the type of sample bottle used.

4) The major source affecting accuracy of the results is the variability in replicate analytical measurements.

Other significant conclusions were drawn from analyses of the data. These conclusions are as follows:

- After 4 days of settling in the MFHT (simulating an unscheduled power outage), less than 2 hours of agitation were required to resuspend and uniformly mix the slurries tested.

- Scale-up of the bench-scale tests was verified qualitatively. It was shown that the mixing system operated in the turbulent flow region and the liquid in the tank was homogeneous. A precise verification of scale-up of bench-scale data was not possible due to dissimilarities between the bench- and full-scale mixing systems. 
- The maximum flow rate of the air-displacement slurry (ADS) pump used for the sampling system does not achieve turbulent flow in a 0.5 -in.-(inside)-dia. pipe, which may result in a nonrepresentative sample due to solids settling in the lines.

- The mixing Reynolds numbers calculated for the three concentrations of slurry tested were 1 to 2 orders of magnitude greater than the Reynolds number at which fully turbulent mixing is defined. This implies that the speed of the agitator could be reduced without affecting the homogeneity of the feed in the MFHT, if slurry settling rates are similar to the tested slurries.

The following are recommendations for improving the consistency of the melter feed and reducing the number of required analyses per sample.

- A significant portion of the analytical uncertainty was due to long-term effects (e.g., lab conditions, calibration procedures). A statistical quality control program, detailed in Section 6.5 , would isolate and eliminate some of the major sources of variation. Reduced analytical uncertainty reduces the number of required analyses per sample, thereby reducing cost.

- Perform characterization tests on the actual liquid-sampling system to determine procedures that will provide a more representative sample. These tests should include an evaluation of sample bottle design, sampling cycle times, minimum flow rates, and flushing requirements. 


\section{ACKNOWLEDGMENTS}

The authors would like to acknowledge the efforts of Brian Bauer (responsible engineer at West Valley), and Mary Peterson (PNL). Brian's attention to detail contributed a tremendous amount to the success of the tests. Mary's technical expertise and cooperation was invaluable throughout the entire study. 
•

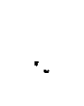

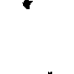




\section{CONTENTS}

SUMMARY ..............................

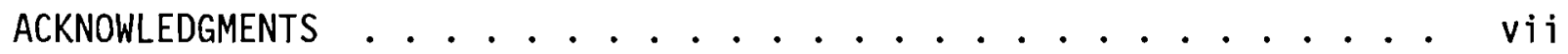

1.0 BACKGROUND AND OBJECTIVES ........................ 1.1

2.0 CONCLUSIONS AND RECOMMENDATIONS . . . . . . . . . 2.1

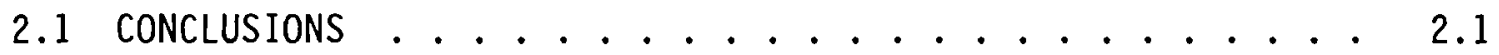

2.2 RECOMMENDATIONS . . . . . . . . . . . . . . 2.2

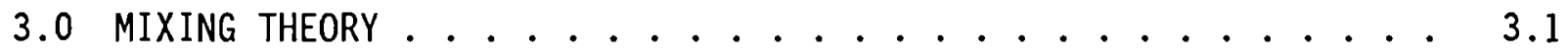

3.1 PSEUDOHOMOGENEOUS, NON-NEWTONIAN SLURRIES . . . . . . 3.1

3.2 SOLID-LIQUID MIXING $\ldots \ldots \ldots \ldots$

3.3 SCALE-UP OF BENCH-SCALE DATA . . . . . . . . . . 3.9

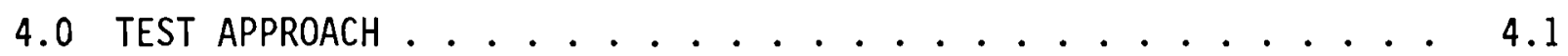

4.1 STATISTICAL EXPERIMENTAL DESIGN . . . . . . . 4.3

4.1.1 Standard Deviation of Replicate Samples and

Analyses ................ 4.3

4.1.2 Probability of Erroneous Conclusions . . . . . 4.4

4.1.3 Desired Detectable Differences . . . . . . 4.4

4.1.4 Number of Samples per Location/STurry Combination . . 4.4

4.2 HOMOGENEITY/SAMPLING SYSTEM TESTS . . . . . . . 4.5

4.3 RESUSPENSION TEST . . . . . . . . . . . . . . 4.6

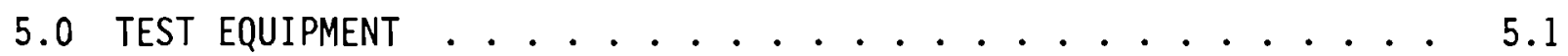

5.1 WEST VALLEY MELTER FEED HOLD TANK . . . . . . . 5.1

5.2 MECHANICAL LIQUID-SAMPLING SYSTEM . . . . . . . 5.1

5.2.1 Air-Displacement S7urry Pump ........ 5.3

5.2.2 Hydragard Series 2000 Liquid Sampler . . . . . 5.4 
5.3 BOTTLE-AND-ROD TANK SAMPLER $\ldots \ldots \ldots \ldots . \ldots . \ldots$

5.4 HAAKE VISCOMETER . . . . . . . . . . . 5.8

5.5 BENCH-SCALE MIXING SYSTEM . . . . . . . . . . . 5.9

6.0 EXPERIMENTAL RESULTS AND DISCUSSION . . . . . . . . . 6.1

6.1 WASTE CHARACTERIZATION ..................... 6.1

6.1 .1 Physical Properties ............ 6.2

6.1 .2 Rheological Properties ........... 6.2

6.2 STATISTICAL ANALYSIS OF THE DATA . . . . . . 6.6

6.3 HOMOGENEITY/SAMPLING SYSTEM TESTS . . . . . . . 6.7

6.4 RESUSPENSION TESTS . . . . . . . . . . . . 6.15

6.4.1 Concentrated Melter Feed S1urry . . . . . . . 6.17

6.4.2 Reference Melter Feed Slurry ......... 6.18

6.4.3 Dilute Melter Feed Slurry . . . . . . . . 6.19

6.5 ANALYTICAL UNCERTAINTIES . . . . . . . . . . 6.20

6.6 SCALE-UP VERIFICATION . . . . . . . . . . 6.22

6.6.1 Geometric Similarities .......... 6.22

6.6.2 Kinematic and Dynamic Similarities ...... 6.22

6.6 .3 Conclusions ................. 6.26

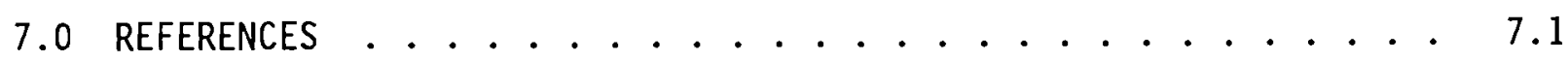

APPENDIX A - SAMPLE AND ANALYSIS ORDER . . . . . . . . A.1

APPENDIX B - STATISTICAL ANALYSES RESULTS . . . . . . . B.1 


\section{FIGURES}

3.1 Rheograms for Time-Independent Fluids . . . . . . . . . . 3.2

3.2 Viscosity Versus Shear Rate for Time-Independent Fluids . . . . 3.3

3.3 Power Number Versus Reynolds Number Relationship for Bench-Scale Mixing Configuration ............ 3.6

3.4 Flow Pattern for Dual Axial-Flow Turbines . . . . . . . . . 3.9

4.1 Sample Point Locations . . . . . . . . . . . . . 4.2

5.1 Schematic of West Valley Melter Feed Hold Tank . . . . . . . 5.2

5.2 Operating Cycles of ADS Pump . . . . . . . . . . . . 5.3

5.3 Hydragard Series 2000 Liquid-Sampler . . . . . . . . . 5.5

5.4 Sample Bottles for Hydragard Liquid-Sampler . . . . . . . . . 5.6

5.5 Schematic of Bottle-and-Rod Tank Sampler . . . . . . . . . 5.7

5.6 Flow Curve (Rheogram) for a Yield-Pseudoplastic Fluid . . . . 5.9

5.7 Bench-Scale Mixing System . . . . . . . . . . . . 5.10

5.8 Bench-Scale Impellers . . . . . . . . . . . . . . 5.11

6.1 Rheogram of Combined Sample of the Reference Melter Feed Slurry ..................... . . 6.3

6.2 Rheogram of Combined Sample of the Dilute Melter Feed Slurry • • 6.3

6.3 Rheogram of Combined Sample of the Concentrated Melter Feed Slurry ....................... 6.4

6.4 Total Solids Versus Analytical Order for the Control Samples . . 6.18

6.5 Power Number Versus Reynolds Number for the Bench-Scale and Full-Scale Mixing Systems 


\section{$\underline{\text { TABLES }}$}

3.1 Dimensionless Groups for Fluid Mixing Applications . . . . . . 3.5

3.2 Scale of Agitation for Solids Suspension . . . . . . . . . 3.8

3.3 Scale-Up Exponents for Agitation ............. 3.11

6.1 Physical Properties of Melter Feed Slurries . . . . . . . . 6.2

6.2 Rheological and Transport Properties of Combined Melter

Feed Samples for Slurry Sampling System ........... 6.5

6.3 Outliers That Were Deleted from All Statistical Analyses . . . 6.9

6.4 Estimates of the Inhomogeneity and Analytical Variations

Using the As-Analyzed Data ............. 6.11

6.5 Sampler System Bias and Relative Bias for As-Analyzed Data . . 6.12

6.6 Estimates of the Inhomogeneity and Analytical Variations Using the Normalized Data ............. 6.13

6.7 Sampler System Bias and Relative Bias for Normalized Data . . . 6.15

6.8 Results of Statistical Analysis of Resuspension Data . . . . 6.16

6.9 Averages Representing the Significant Effects Shown in Table 6.8....................... 6.19

6.10 Comparison of Geometric Mixing System Parameters . . . . . 6.23

6.11 Comparison of Kinematic and Dynamic Mixing System Parameters . . 6.24

6.12 Scale of Agitation . . . . . . . . . . . 6. 6.25 


\subsection{BACKGROUND AND OBJECTIVES}

High-level radioactive liquid wastes are stored in underground tanks at several Department of Energy (DOE) facilities in the United States, including the Savannah River Plant (SRP) in Aiken, South Carolina; the West Valley Demonstration Project (WVDP) in West Valley, New York; and the Hanford Site near Richland, Washington. The current $\mathrm{plan}$ for managing high-level radioactive wastes is to convert the waste to a durable borosilicate glass, and isolate the glass in a deep geologic repository.

The process for converting the wastes to glass involves mixing the highlevel wastes (HLW) with glass-forming chemicals. The resulting slurry is then transferred to a feed tank and processed through a high-temperature furnace known as a slurry-fed ceramic melter (SFCM). Maintaining the quality of the glass product and safe, efficient operation of the melter depends on the ability of the melter slurry preparation and feed systems to produce and maintain a homogeneous mixture of waste and glass-former materials.

As part of the Nuclear Waste Treatment Program (NWTP), Pacific Northwest Laboratory (PNL) conducted bench-scale tests in FY 1986 to provide a quantitative description of the performance of several feed mixing systems in terms of measurable process variables (Peterson, McCarthy and Muhlstein 1986). One of the systems studied was the West Valley melter feed hold tank (MFHT). For this system, the HLW and glass-former mixture is fed from the MFHT into the melter. The bench-scale study used simulated West Valley melter feed to determine the size of the full-scale agitator that is used to mix the slurry in the MFHT.

In FY 1987, PNL was funded by the NWTP to verify the scale-up of the bench-scale studies. A collaboration between PNL and West Valley concluded with verification tests performed at West Valley using their melter feed system. This arrangement met the objectives of the NWTP, and also provided information to West Valley for characterizing their melter feed system.

The objectives of this study, which was conducted by PNL for the NWTP and WVDP, are as follows: 1) quantify the homogeneity of the melter slurry in the MFHT, 2) determine the representativeness of the slurry sample 
obtained by the liquid-sampling system in the MFHT, 3) determine the time required to resuspend the solids and homogenize the melter slurry in the MFHT after a simulated, unexpected power outage, and 4) verify the scale-up of the results from the bench-scale mixing study. 


\subsection{CONCLUSIONS AND RECOMMENDATIONS}

Large-scale mixing tests were performed at West Valley to determine whether the agitator in the MFHT adequately mixes the slurry, and whether the liquid-sampling system installed in the tank provides a representative sample of the slurry. In addition, the tests were performed to verify scale-up of data from bench-scale mixing tests performed by PNL in FY 1986 . The objective of the bench-scale tests was to calculate full-scale mixing parameters based on bench-scale data.

Section 2.1 presents the conclusions from the full-scale tests. Section 2.2 lists recommendations for improving the quality of the glass product and reducing the number of required analyses per sample.

\subsection{CONCLUSIONS}

The following is a list of significant conclusions drawn from the largescale mixing tests:

- Analysis of normalized values can sometimes mask interactions. It can be deceptive when certain conditions affect some elements but not others, or affect all elemental constituents similarly. This can have significant impact during feed makeup.

- The major source affecting accuracy of the results is the variability in replicate analytical measurements.

- The $15 \mathrm{Hp}$, single-speed (155 rpm) agitator installed in the MFHT produces a homogeneous mixture for the three concentrations of simulated melter feed slurry used in these tests. Slurries with significantly greater settling rates may produce different results.

- The 1iquid-sampling system installed in the MFHT obtains samples that are up to $2.6 \%$ higher in total solids. This may be due to the flow rate of the slurry and/or the type of sample bottle used.

- After 4 days of settling in the MFHT (simulation of an unscheduled power outage), less than 2 hours of agitation were required to resuspend and uniformly mix the slurries tested.

- The maximum flow rate of the air-displacement slurry (ADS) pump used for the sampling system does not achieve turbulent flow in a 0.5-in.-(inside)-dia. pipe, which may result in a nonrepresentative sample due to solids settling in the lines. 
- Scale-up of the bench-scale tests was qualitatively verified by showing that the mixing system operated in the turbulent flow region and the liquid in the tank was homogeneous. A precise verification of scale-up of bench-scale data was not possible due to dissimilarities between the two mixing systems.

- The mixing Reynolds numbers calculated for the three slurry concentrations that were tested were 1 to 2 orders of magnitude greater than the Reynolds number at which fully turbulent mixing is defined. This difference implies that the speed of the agitator could probably be reduced without affecting the homogeneity of the slurry in the MFHT. A reduction of agitator speed would 1) prevent vortexing, which could decrease the accuracy of the liquid-level detector; 2) decrease the erosion rate of the impeller blades; 3 ) decrease the chance of splashing slurry on internal equipment (which could decrease corrosion); and 4) increase the efficiency of the ADS pump at low liquid levels (air entrainment affects ADS pump operation).

\subsection{RECOMMENDATIONS}

The following are recommendations for improving the consistency of the melter feed and reducing the number of required analyses per sample.

- Statistical analysis of all inductively coupled plasma (ICP) data that are available from these tests should be completed. In this study, data from only the seven major soluble and insoluble constituents were analyzed to determine homogeneity. Analysis of the other constituents would provide relative standard deviation measurements that are important for waste form qualification and for increasing the accuracy of the cold chemical addition recipe.

- Characterization tests on the actual liquid-sampling system should be performed to determine procedures that will provide a more representative sample. These tests should include an evaluation of sample bottle design, sampling cycle times, minimum flow rates, and flushing requirements.

- A significant portion of the analytical uncertainty was due to long-term effects (e.g., lab conditions, calibration procedures). A statistical qual ity control program as detailed in Section 6.5 would isolate and eliminate some of the major sources of variation. Reduced analytical uncertainty reduces the number of required analyses per sample, thereby reducing cost. 


\subsection{MIXING THEORY}

The procedures used to design the slurry mixing processes are based on classical rheological models for homogeneous and heterogeneous flow systems. (Rheology is the field of study concerned with the deformation and flow of materials.) The models were used to classify the West Valley melter feed slurry, and verify the scale-up of the bench-scale data. The theoretical models used to define the non-Newtonian behavior of the melter feed slurry are described in Section 3.1. The design of solid-liquid mixing systems is discussed in Section 3.2. Section 3.3 presents the method used to scale-up the bench-scale data.

\subsection{PSEUDOHOMOGENEOUS, NON-NEWTONIAN SLURRIES}

Viscous, single-phase fluids and pseudohomogeneous, multiphase fluid mixtures (like melter feed) are classified according to their response to shearing stresses. A shear stress is defined as:

$$
\tau=\frac{\mathrm{F}}{\mathrm{A}}
$$

where $\tau=$ shear stress

$F=$ force

$A=$ area.

For Newtonian fluids in laminar flow:

$$
\tau=\mu\left(\frac{d v}{d y}\right)
$$

where $\mu=$ viscosity

$$
\mathrm{dv} / \mathrm{dy}=\text { shear rate in } \mathrm{y} \text { direction }
$$

The viscosity, $\mu$, is a proportionality constant that is independent of shear rate and affected only by pressure and temperature for a Newtonian fluid. A plot of shear stress versus rate of shear in the laminar flow regime is known as a rheogram (Figure 3.1). The slope of the curve is constant for a Newtonian fluid. All fluids that display rheograms that are not linear 


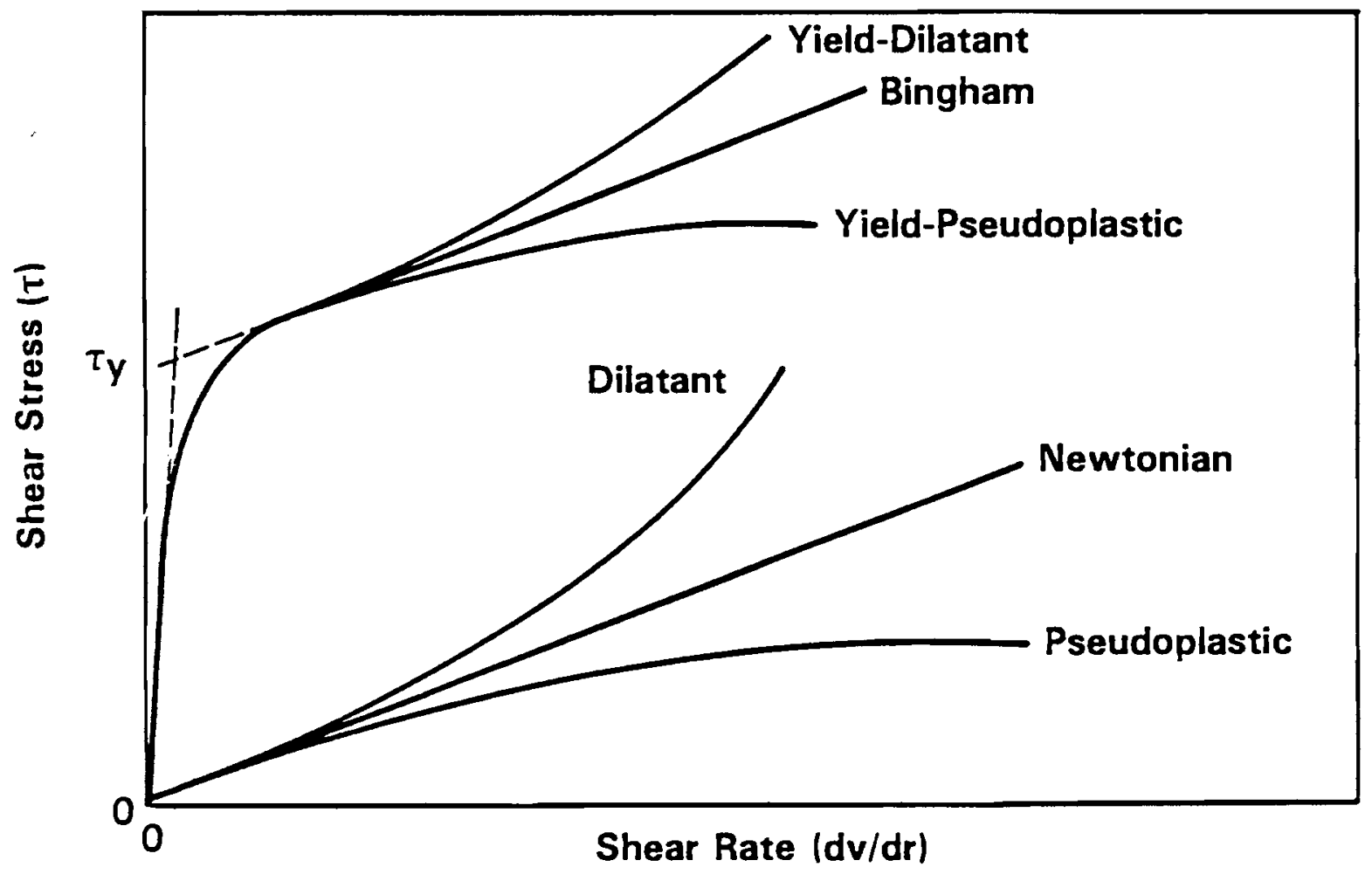

FIGURE 3.1. Rheograms for Time-Independent Fluids

through the origin are considered to be non-Newtonian. Non-Newtonian fluids are usually classified as time-independent, time-dependent, or viscoelastic fluids. Since most melter feed slurries are considered time-independent fluids, only that type of fluid will be discussed in this report.

Figure 3.1 presents rheograms for classical time-independent, nonNewtonian fluids. The relationship between apparent viscosity and shear rate for these fluids is described by Figure 3.2. The apparent viscosity is a function of shear rate for non-Newtonian fluids and is analogous to the Newtonian viscosity for Newtonian fluids.

Non-Newtonian fluids are typically classified as fluids with yield stresses and fluids without yield stresses. These classifications are further defined as fluids that decrease in viscosity with increasing applied shear rate (pseudoplastic or yield-pseudoplastic, if the slurry has a yield stress), and fluids that increase in viscosity with increasing applied shear rate (dilatant or yield-dilatant). 


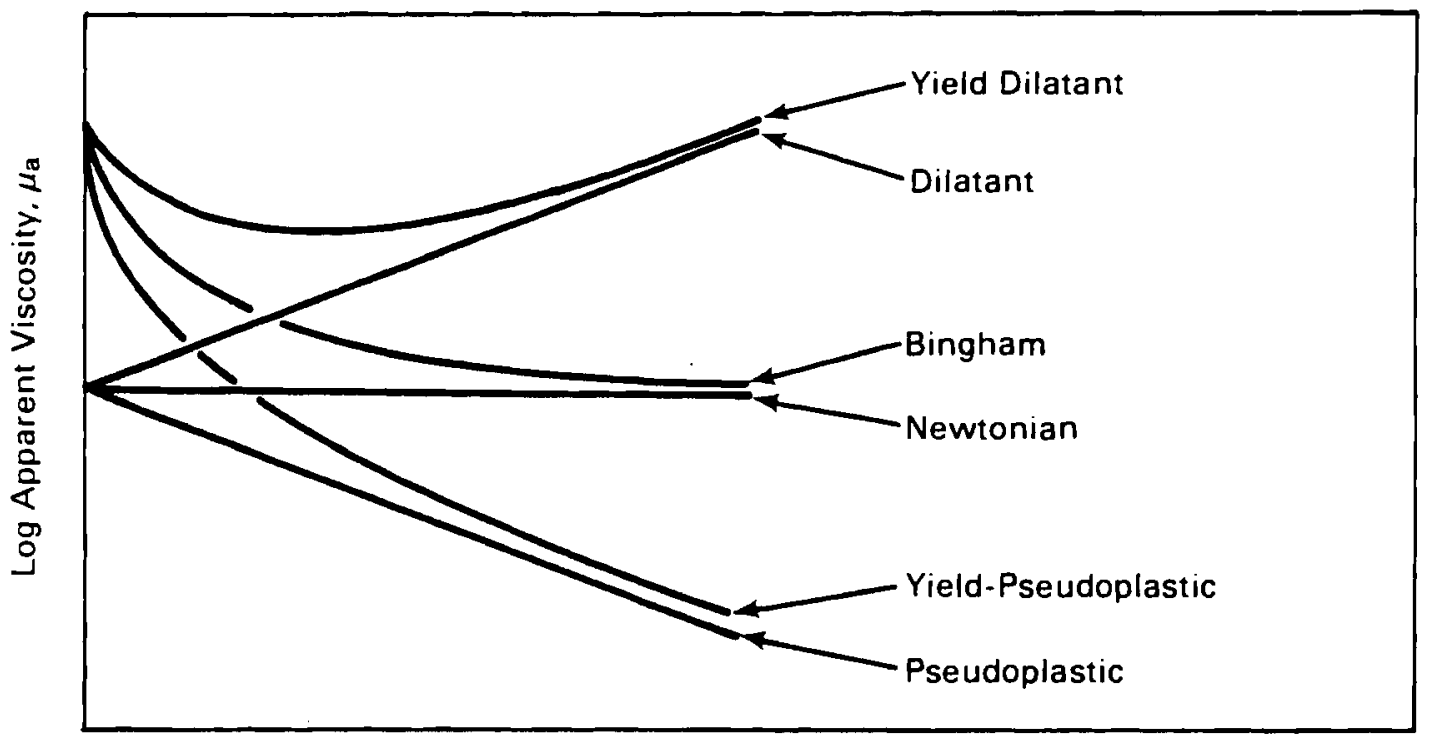

Log Shear Rate, dv/dy

FIGURE 3.2. Viscosity Versus Shear Rate for Time-Independent Fluids

The rheological behavior of a non-Newtonian fluid can be represented by the following equation:

$$
\tau=\tau_{y}+K\left(\frac{d v}{d y}\right)^{n}
$$

$$
\text { where } \begin{aligned}
\tau & =\text { shear stress, } \mathrm{N} / \mathrm{m}^{2} \text { (Pascal) } \\
\tau_{y} & =\text { yield stress, } \mathrm{N} / \mathrm{m}^{2} \\
\mathrm{~K} & =\text { consistency index, } \mathrm{Ns} / \mathrm{m}^{2} \\
\mathrm{dv} / \mathrm{dy} & =\text { shear rate in } \mathrm{y} \text { direction, } \mathrm{sec}^{-1} \\
\mathrm{n} & =\text { flow behavior index. }
\end{aligned}
$$

The yield-power law model defined by Equation (3.3) reduces to the Bingham Plastic model when $n=1$, the power 1 aw model when $\tau_{y}=0$, and the Newtonian model when $\tau_{y}=0$ and $n=1$.

Since the bulk of the available mixing data is based on Newtonian fluids, it is convenient to define an apparent viscosity as follows: 


$$
\mu a=\frac{\tau}{\left(\frac{d v}{d y}\right)}=\frac{\tau y+K\left(\frac{d v}{d y}\right)^{n}}{\left(\frac{d v}{d y}\right)}
$$

The apparent viscosity for non-Newtonian fluids is a function of the shear rate. The average shear rate in a mixing system is a function of the level of agitation and is defined as (Metzner and 0tto 1957):

$$
\left(\frac{d v}{d y}\right)_{\text {average }}=k N
$$

Values of the proportionality constant for the mixing shear rate, $k$, have been established for common impeller configurations. The average value of $k$ for single and double impeller configurations is approximately 11.5 (Peterson, McCarthy and Muhlstein 1986). This number was used to determine the shear rate in the bench-scale and full-scale mixing tanks.

\subsection{SOLID-LIQUID MIXING}

Although many variables are involved in fluid mixing, a relatively small number of dimensionless groups (Table 3.1) and corresponding functional relationships can be derived by using dimensional analysis. The following functional relationship can be obtained from consideration of a mass and momentum balance around a mixing vessel for a constant density Newtonian fluid (Bird et a1. 1960, Dickey and Fenic 1976, Bates et al. 1966).

$$
N_{p}=f\left[R e, F r, \frac{T}{D}, \frac{L}{D}, \frac{C}{D}, \frac{p}{D}, \frac{W}{D}, \frac{B}{B_{0}}\right]
$$

where $N_{p}=$ power number $=\frac{P}{\rho N^{3} D^{5}}$

$$
\begin{aligned}
& \mathrm{Re}=\text { Reynolds number }=\frac{\rho N D^{2}}{\mu} \\
& \mathrm{Fr}=\text { Froude number }=\frac{N^{2} \mathrm{D}}{\mathrm{g}}
\end{aligned}
$$




$$
\begin{aligned}
B & =\text { number of blades } \\
B_{0} & =\text { reference number of blades } \\
C & =\text { clearance between the impeller and tank bottom, } m \\
D & =\text { impeller diameter, } \mathrm{m} \\
\mathrm{L} & =\text { liquid level in tank, } \mathrm{m} \\
\mathrm{P} & =\text { impeller pitch, } \mathrm{m} \\
\mathrm{P} & =\text { power applied to fluid, } \mathrm{W} \\
\mathrm{N} & =\text { impeller rotational speed, rps } \\
W & =\text { impeller blade width, } \mathrm{m} \\
T & =\text { diameter of tank, } \mathrm{m} \\
\mu & =\text { fluid viscosity, } \mathrm{Pa} \cdot \mathrm{s} \\
\rho & =\text { fluid density, } \mathrm{kg} / \mathrm{m}^{3} \\
\mathrm{~g} & =\text { gravitational constant, } \mathrm{m} / \mathrm{s}^{2}
\end{aligned}
$$

\begin{tabular}{|c|c|c|}
\hline Name & Formula & Relationship \\
\hline Froude number & $\mathrm{Fr}=\mathrm{DN}^{2} / \mathrm{g}$ & inertial/gravitational forces \\
\hline Power number & $N_{p}=P g / \rho N^{3} D^{5}$ & imposed/inertial forces \\
\hline Pumping number & $N_{Q}=Q / N D^{3}$ & turnovers \\
\hline $\begin{array}{l}\text { Reynolds number } \\
\text { where } Q=\text { volume }\end{array}$ & $\operatorname{Re}=D^{2} \mathrm{~N} \rho / \mu$ & inertial/viscous forces \\
\hline
\end{tabular}

For mixing systems that are geometrically similar, the functional relationship can be reduced to:

$$
N_{p}=f[R e, F r]
$$

The Froude number is a significant variable in mixing systems only where a free liquid surface exists and the flow pattern is affected by gravity. This can be significant in unbaffled tanks when vortexing is occurring. In baffled tanks such as the MFHT, vortexing generally does not occur and the

IABLE 3.1. Dimensionless Groups for Fluid Mixing Applications 
Froude number is not important. Equation (3.10) can be simplified to:

$$
N_{p}=f[R e]
$$

Figure 3.3 presents an example of this functional relationship for a bench-scale mixing system that was intended to be geometrically similar to the MFHT (Peterson, McCarthy and Muhlstein 1986). There are three regions of interest on the curve--the viscous, transition, and turbulent regions. The viscous or laminar region occurs below a mixing Reynolds number, Re, of about 20. The fully turbulent region, where inertial forces dominate, typically begin at an $\operatorname{Re}$ of 1,000 to 10,000 , depending on the impeller type. In the turbulent region the power number becomes independent of the Re. The region between laminar and turbulent is the transition region.

Another important dimensionless number is the flow number, $\mathrm{N}_{Q}$. This dimensionless quantity is defined by the following equations:

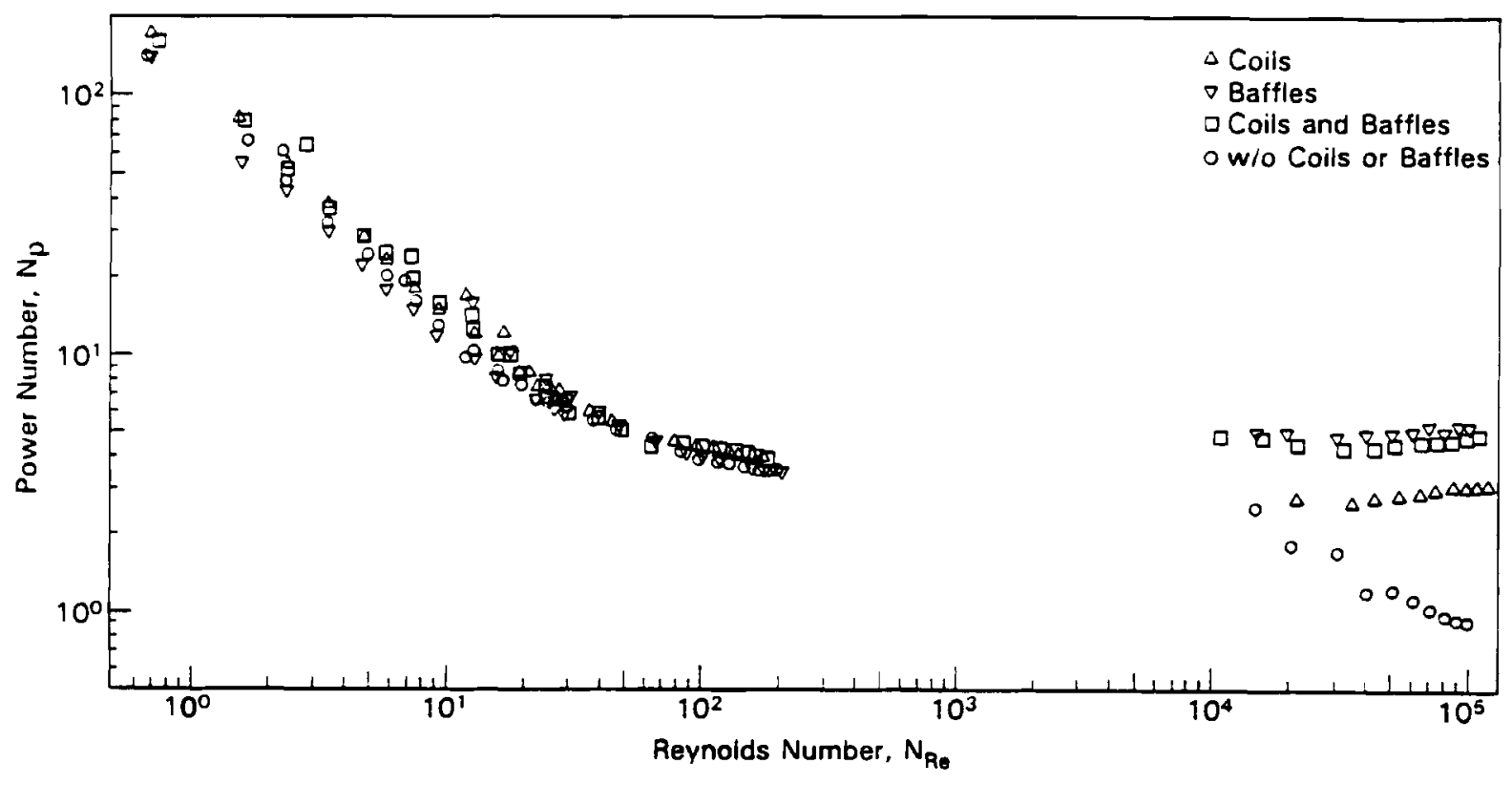

FIGURE 3.3. Power Number Versus Reynolds Number Relationship for BenchScale Mixing Configuration (Peterson, McCarthy and Muhlstein 1986) 


$$
\begin{aligned}
& N=\frac{Q}{N D^{3}} \\
& Q=v_{b} A
\end{aligned}
$$

where $Q=$ volumetric flow rate, $L / m i n$

$$
\mathrm{N}=\text { rotational speed, } \mathrm{rpm}
$$

$D=$ impeller diameter, $\mathrm{cm}$

$\mathrm{N}_{\mathrm{Q}}=$ pumping number

$v_{b}=$ bulk velocity, $\mathrm{cm} / \mathrm{s}$

$A=$ cross sectional area of mixing tank, $\mathrm{cm}^{2}$

The flow number provides an indication of the pumping capacity of an agitator and the turnover rate of the tank contents.

In considering the extent of solids suspension in an agitated tank, it is useful to define a scale of agitation that ranges from one to ten as shown in Table 3.2 (Gates, Morton and Fondy 1976). An increasing scale number indicates an increasing level of solids suspension and mixing homogeneity. Bulk liquid velocities are related to the scale of agitation, $N_{I}$, by Equation 3.14 (Hicks, Morton and Fenic 1976):

$$
N_{I}=\frac{v_{b}}{3.05} \quad \text { The units on } v_{b} \text { are } \mathrm{cm} / \mathrm{s} \text {. }
$$

Some numerical values for the bulk velocity are shown in Table 3.2. Since a nearly homogeneous melter feed is important for producing a high-quality glass waste form, a scale of agitation of 8 to 10 is necessary for the melter feed slurry application.

The high-efficiency turbine blades installed in the West valley mixing system produce a primarily axial flow pattern (Figure 3.4 ). This flow pattern is useful in solids suspension applications since it directs the flow of liquid downward, which tends to sweep solids from the bottom of the tank and prevent solids deposition. 
TABLE 3.2. Scale of Agitation for Solids Suspension

Bulk

Scale of Velocity

Agitation $\mathrm{cm} / \mathrm{s}$ (fpm)

1

$3.0(6)$

$6.1(12)$

Description

2

$6.1(12)$

Agitation levels 1-2 characterize applications requiring minimal solids-suspension levels to achieve the process result.

Agitators capable of scale level 1 will:

- Produce motion of all of the solids of the design-settling velocity in the vessel.

- Permit moving fillets of solids on the tank bottom, which are periodically suspended.

Agitation levels 3-5 characterize solids-suspension

$\begin{array}{ll}4 & 12.2(24) \\ 5 & 15.2(30)\end{array}$
applications for most chemical-process industries. This scale range is typically used for dissolving solids.

Agitators capable of scale level 3 will:

- Suspend all of the solids of design-settling velocity completely off the vessel bottom.

- Provide slurry uniformity to at least one-third of fluid-batch height.

- Be suitable for slurry drawoff at low exitnozzle elevations.

Agitation levels 6-8 characterize applications where

$7 \quad 21.3(42)$

$8 \quad 24.4(48)$ the solids-suspension level approaches uniformity.

Agitators capable of scale level 6 will:

- Provide concentration uniformity of solids to $96 \%$ of the fluid-batch height.

- Be suitable for slurry drawoff up to $80 \%$ of fluid batch height.

$\begin{array}{rrr}9 & 27.4(54) \\ 10 & 30.5(60)\end{array}$

Agitation levels 9-10 characterize applications where the solids-suspension uniformity is the maximum practical.

Agitators capable of scale level 9 will:

- Provide slurry uniformity of solids to $98 \%$ of the fluid-batch height.

- Be suitable for slurry drawoff by means of overflow.

Source: Gates, Morton and Fondy 1976. 


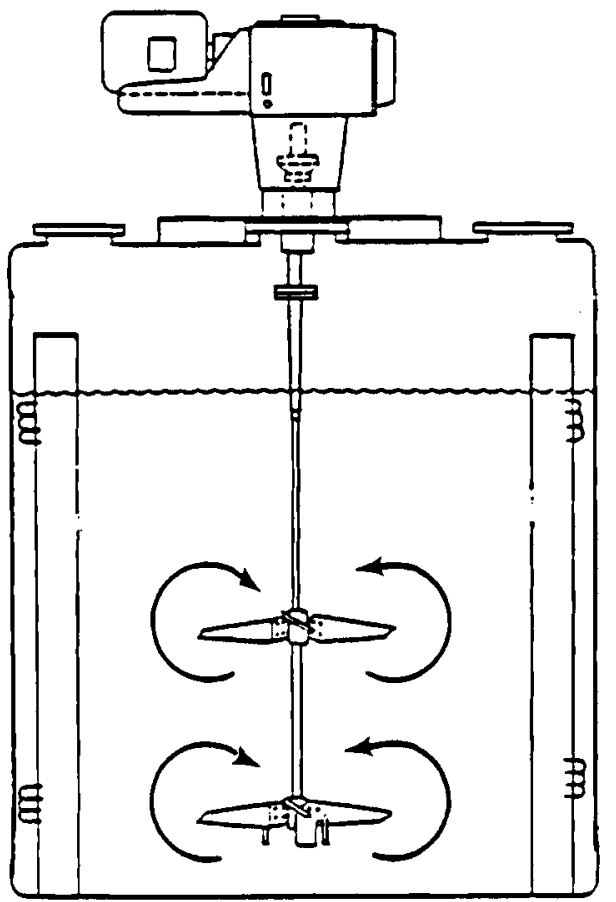

FIGURE 3.4. Flow Pattern for Dual Axial-Flow Turbines

\subsection{SCALE-UP OF BENCH-SCALE DATA}

Bench-scale systems are designed to be as geometrically, kinematically, and dynamically similar to full-scale equipment as practical. Geometric similarity requires that the ratio of corresponding dimensions be identical in bench- and full-scale equipment. Emphasis is placed on maintaining certain ratios, including liquid level/tank diameter $(L / T)$, blade diameter/tank diameter $(D / T)$, distance between bottom blade and tank floor/blade diameter $\left(C_{1} / D\right)$, blade width/blade diameter $(W / D)$, and width of the baffles/tank diameter $\left(B_{W} / T\right)$.

Kinematic similarity is normaliy defined in terms of ratios of corresponding velocities. This definition is comparable to a dimensionless velocity distribution, which is a ratio with respect to a reference velocity such as impeller tip speed. It has been shown by fundamental and experimental analyses that the dimensionless velocity distribution becomes constant in turbulent agitation. A constant dimensionless velocity distribution results 
in fixed ratios between corresponding velocities. As a result, kinematic similarity occurs with geometric similarity in turbulent agitation (Rautzen, Corpstein and Dickey 1976).

Dynamic similarity requires that fixed ratios of corresponding forces (inertial, viscous, and gravitational) be held constant. The mixing parameters that relate to these forces are listed in Table 3.1. All of these parameters are a function of both impeller speed, $\mathrm{N}$, and blade diameter, $\mathrm{D}$. It is not possible to hold both $N$ and $D$ constant during scale-up. In addition, the size distribution of particles in solid-liquid agitation systems will not change as the size of the agitation system is scaled up or scaled down.

An empirical approach must be taken to scale-up the bench-scale mixing results. Bench-scale tanks are fabricated to assure dimensional similarity. The range of impeller rotation speeds evaluated is chosen to induce tip speeds that bracket the speeds often used in full-scale equipment. Finally, a scale-up rule is chosen that accounts for the dynamic dissimilarity that will exist between the bench-scale and full-scale equipment.

Geometric similarity fixes the value of $D$ for each of the dynamic similarity parameters listed in Table 3.1. As a result, the scale-up problem becomes one of determining the appropriate large-scale impeller speed. The selection of the appropriate scale-up rule to establish this rotational speed is based on documentation (Rautzen, Corpstein and Dickey 1976) that identifies a scale ratio, $R$, as:

$$
R=\left(\frac{V_{2}}{V_{1}}\right)^{1 / 3}
$$

where the subscript 2 refers to large-scale equipment and the subscript 1 refers to bench-scale equipment.

The scale ratio is used to fix the physical dimensions of the fullscale equipment as follows: 


$$
\mathrm{R}=\frac{\mathrm{L}_{2}}{\mathrm{~L}_{1}}=\frac{\mathrm{T}_{2}}{\mathrm{~T}_{1}}=\frac{\mathrm{D}_{2}}{\mathrm{D}_{1}}=\frac{\mathrm{W}_{2}}{\mathrm{~W}_{1}}=\frac{\mathrm{B}_{\mathrm{W}}}{\mathrm{B}_{\mathrm{W} 1}} \text { etc. }
$$

The large-scale impeller speed is then related to bench-scale impeller speed. This relationship adjusts the scale ratio, $R$, by raising it to an exponent, $\mathrm{m}:$

$$
\frac{\mathrm{N}_{2}}{\mathrm{~N}_{1}}=\left(\frac{1}{\mathrm{R}}\right)^{\mathrm{m}}
$$

The selection of the exponent, $m$, is based on a knowledge of the controlling mixing class in the agitation system and on experience. The levels of $\mathrm{m}$ associated with common mixing applications are indicated in Table 3.3. Detailed information on a scale-up procedure applied to the MFHT can be found in Peterson, McCarthy and Muhlstein 1986.

\begin{tabular}{|c|c|c|c|}
\hline Mixing Application & $\begin{array}{c}\text { Dominant Impeller } \\
\text { Effect }\end{array}$ & Description & $\begin{array}{c}\text { Exponent, } \\
\mathrm{m}\end{array}$ \\
\hline Equal blending time & -- & $\begin{array}{l}\text { Reaction time is } \\
\text { controlling }\end{array}$ & 0 \\
\hline Equal surface motion & $\begin{array}{l}\text { Shear rate } \\
\text { (Fr, tip speed) }\end{array}$ & Vortex formation & $1 / 2$ \\
\hline Equal mass transfer & $\begin{array}{l}\text { Shear rate/flow } \\
\text { (power/volume, } \\
\text { tip speed) }\end{array}$ & $\begin{array}{l}\text { Liquid motion } \\
\text { Turbulence } \\
\text { Dispersion of solids }\end{array}$ & $2 / 3$ \\
\hline $\begin{array}{l}\text { Equal solids } \\
\text { suspension }\end{array}$ & Flow $\left(N_{Q}\right)$ & Suspension of solids & $3 / 4$ \\
\hline Equal liquid motion & $\begin{array}{l}\text { Flow } \\
\text { (torque/volume) }\end{array}$ & $\begin{array}{l}\text { Corresponding } \\
\text { Velocities are equal }\end{array}$ & 1 \\
\hline
\end{tabular}

\section{TABLE 3.3. Scale-Up Exponents for Agitation}




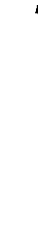




\subsection{IEST APPROACH}

Two types of tests were performed at West Valley using three concentrations of simulated, nonradioactive melter feed slurry. The tests are identified as the homogeneity/sampling system test and the resuspension test and are described in more detail in Sections 4.2 and 4.3 , respectively. The melter slurry concentrations that were tested included the reference melter feed, the reference melter feed concentrated to 75 vol\% (concentrated feed), and the reference melter feed diluted to 125 vol\% (dilute feed). The physical properties of the slurry are presented in Table 6.1.

The tests were statistically designed by PNL to determine whether an adequately homogeneous slurry is obtained in the MFHT, and whether the liquid-sampling system provides a representative sample of the melter feed. The homogeneity of the slurry was measured by comparing the average weight percent solids and the elemental concentrations of slurry samples taken from six sampling locations within the tank, as shown in Figure 4.1. All sampling locations are at about the same radial distance from the agitator. As a result, homogeneity of the slurry as a function of radial distance cannot be determined. However, bench-scale test data indicated that homogeneity of the slurry did not vary with radial distance. The full-scale system is expected to yield the same results.

The ability of the sampling system to obtain a representative sample from the tank was determined by comparing the average weight percent solids and the elemental concentrations from the samples obtained at the six tank sampling locations to those from the sampling system. Section 4.1 discusses the assumptions made to determine the number of required samples at each of the sampling locations.

Samples were taken from the tank and analyzed in random order for weight percent solids and elemental concentrations (ICP analyses) at West Valley. The elemental concentrations were used to calculate the weight percent oxide. An additional sample was taken from each location during each of the three homogeneity/sampling system tests. These additional samples were sent to PNL for rheological and physical evaluations. The rheological and physical 

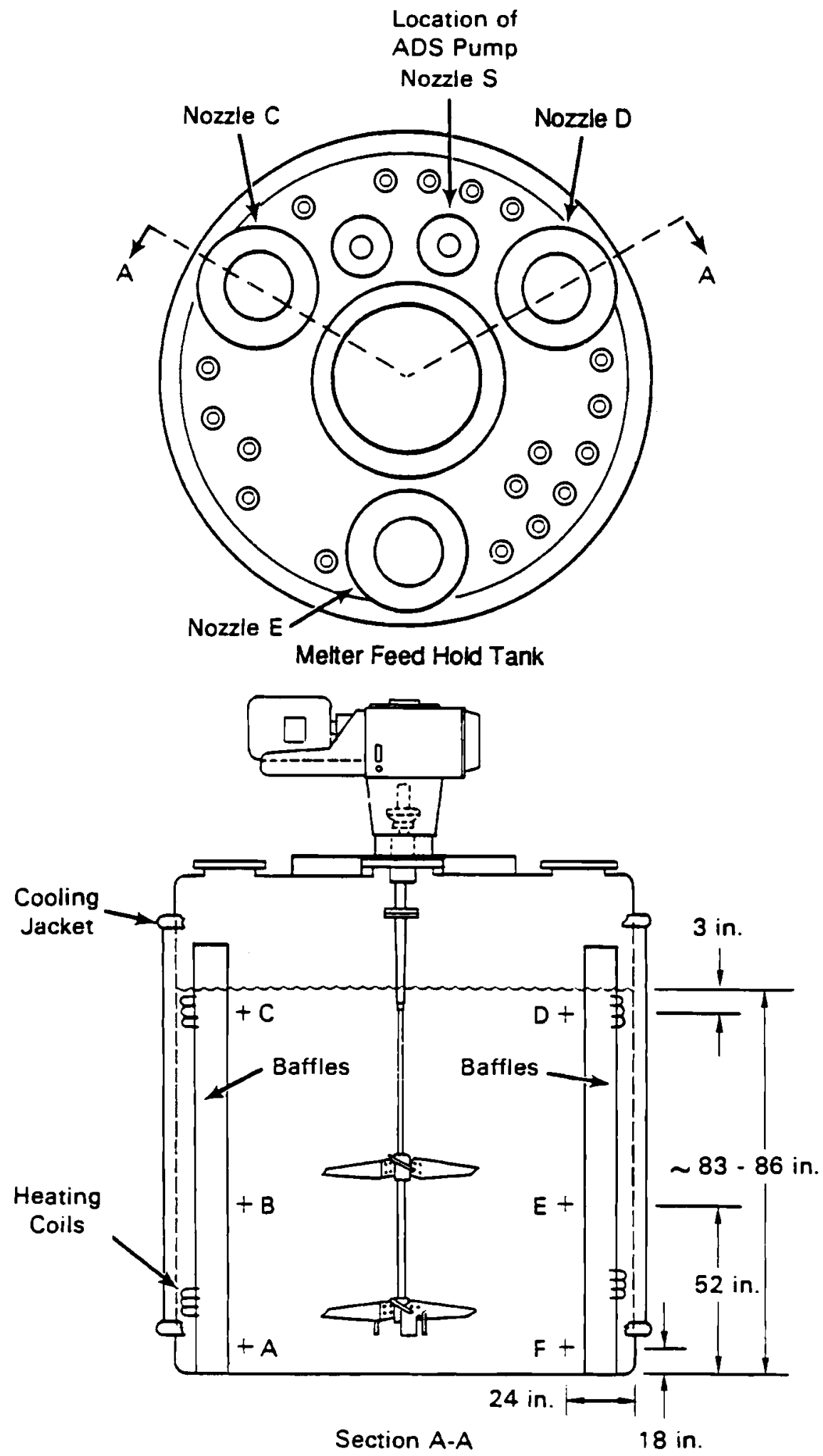

$38806-152.003$

FIGURE 4.1. Sample Point Locations 
characteristics data were used to verify the scale-up of the bench-scale mixing data. Slurry characterization data are presented in Section 6.1, and verification of bench-scale data is discussed in Section 6.6.

\subsection{STATISTICAL EXPERIMENTAL DESIGN}

The tests were statistically designed to provide a high level of confidence regarding the accuracy of the test conclusions. The number of samples required to achieve a high level of confidence is dependent upon several factors, including the size of the standard deviation of replicate samples and analyses, the probability of making erroneous conclusions from statistical tests concerning the homogeneity of the slurry, and the desired detectable differences between the weight percent solids averages (or elemental concentrations) at different locations within the MFHT.

\subsubsection{Standard Deviation of Replicate Samples and Analyses}

The standard deviation is a measurement of the variability between replicate determinations of the tank contents. The tank contents were determined by measuring the weight percent total solids and elemental weight percents (ICP analyses). A potential exists for random variations between replicate samples obtained from the same location/slurry combination. Additionally, variations exist between replicate analyses of the same sample due to the imprecision of the instrumentation and sample preparation techniques.

The standard deviation of replicate determinations of the tank contents must be determined before examining the required number of replicates at each location. Previously conducted work at PNL on factors affecting homogeneity in a smal1-scale feed tank provided an estimate of the standard deviation of weight percent solids. It was determined that the variability between replicate samples was the major source of variation, and the variability between replicate analyses on the same sample was nearly negligible. For the ful1scale tests, the standard deviation of weight percent total solids was assumed to be equal to the standard deviation obtained from the bench-scale study: 0.9 wt\% (Peterson, McCarthy and Muhlstein 1986).

Standard deviation estimates for the ICP elemental concentration measurements were obtained from a variability study conducted for West Valley at 
PNL by the Materials Characterization Center (MCC). The study suggested that the major source of sample-to-sample variability was due to the imprecision of the ICP analysis process. The relative standard deviation (RSD; the standard deviation represented as a percent of the wt\% average) for seven of the major elements appeared to be less than $4 \%$ in al1 cases. Although these estimates were obtained from experiments conducted using PNL analytical instruments and personnel, they were assumed to be representative of West Valley data.

\subsubsection{Probability of Erroneous Conclusions}

Any test of a hypothesis that involves sampling poses the chance of making an erroneous conclusion. Consider an examination of homogeneity in a tank. If it were concluded that no differences exist between average wt\% solids at different locations, homogeneity is suggested. If it were concluded that differences exist between the averages, lack of homogeneity is suggested. The difference that forms the basis of the conclusion is found by comparing the average weight percent total solids (or elemental weight percent) in a sample for two location/slurry combinations. Drawing the correct conclusion depends on correctly determining whether any differences are statistically significant. Drawing an incorrect conclusion could result in unnecessary process downtime and additional costs. The acceptable probability of not making a false positive or false negative conclusion was chosen by West Valley at 95 percent.

\subsubsection{Desired Detectable Differences}

Because the homogeneity of the solution within the tank was determined by examining the differences between average weight percents, the size of the differences that could adversely affect glass quality was determined. These differences, which should have a high probability of detection, become the desired detectable differences. For this project, the desired detectable differences were identified as approximately 2 to 5 wt\% total solids.

\subsubsection{Number of Samples per Location/Slurry Combination}

The required number of samples was determined using the assumptions described above. For the wt\% total solids determinations, a 0.9 wt\% standard 
deviation was used. Six samples at each of the 18 location/slurry combinations (six sampling locations times three slurry concentrations) results in at least a $95 \%$ chance of detecting a true difference of at least $2.1 \mathrm{wt} \%$ total solids between two of the means.

An RSD of $4 \%$ was used for the elemental weight percent determinations (ICP determinations). Twenty-one samples at each of the 18 location/slurry combinations results in a $95 \%$ chance of detecting a true difference between two of the means of at least $4.5 \%$ of the elemental weight percent.

Therefore, 21 samples were taken at each of the sampling locations for the homogeneity/sampling tests because both weight percent total solids and elemental concentrations were used to determine homogeneity. Six samples at each of the sampling locations were taken for the resuspension tests where wt\% solids was the only criteria for determining homogeneity.

\subsection{HOMOGENEITY/SAMPLING SYSTEM TESTS}

The homogeneity/sampling system test was performed to characterize the melter feed system at West Valley and to verify the scale-up of the benchscale mixing studies performed at PNL. The characterization of the melter feed system included quantifying the homogeneity of the melter feed and determining if the liquid-sampling system obtains representative samples of the slurry. The liquid-sampling system consists of a pulsating air displacement pump that transfers slurry from near the bottom of the tank to an inline sampler approximately $20 \mathrm{ft}$ away.

The homogeneity of the melter feed slurry was quantified from measurements of the wt\% solids and selected elemental concentrations of slurry samples taken from six locations within the MFHT (see Figure 4.1). The representativeness of the sample from the liquid-sampling system was determined by comparing the wt\% solids and selected elemental concentrations of this sample to the samples drawn from the six locations. The samples were taken from the tank in a random order. The sampling order is summarized in Tables A.1 through A.3 of Appendix A. Descriptions of the liquid-sampling system and the device used to take the samples from the tank are provided in Sections 5.2 and 5.3 , respectively. 
The statistical experimental design for the homogeneity/sampling system tests determined that 21 samples were required from each of the six locations in the tank and from the liquid-sampling system. A large number of samples were required because of the imprecision of the instrumentation and sample preparation techniques for the ICP analyses.

Three concentrations of melter feed slurry were tested. The concentrated melter feed slurry was tested first. The simulant was formed in the chemical makeup tank and pumped through a grinder to the MFHT. The grinder theoretically reduces the size of particles in the simulant to less than 200 mesh. The slurry in the MFHT was agitated for several weeks before sampling began. For this test, a total of 154 samples were taken from the tank in a random order--2l samples at each of the 7 sampling locations (as determined by the statistical analysis) and 1 sample from each sampling location, which were combined for rheological and physical analyses. Total sampling time for the first test was 1.5 days. Sampling times decreased with successive tests as the operators gained more experience.

At the end of the homogeneity/sampling system test with the concentrated melter feed slurry, the resuspension test (described in Section 4.3) was started. After the resuspension test, the slurry was diluted to the concentration of the reference melter feed and the homogeneity/sampling system test was repeated, followed by the resuspension test. The slurry was again diluted to 125 vol\% of the reference slurry. Samples were taken for the homogeneity/sampling system test, followed by another resuspension test.

\subsection{RESUSPENSION TESTS}

The resuspension test was performed to determine the time required to resuspend the solids and homogenize the melter slurry in the MFHT after an unexpected power outage. For this test, the agitator was turned off for approximately 4 days. Samples were taken from the tank at the-six specified locations approximately 2, 6, and 24 hours after the agitator was turned back on. The homogeneity of the tank was determined by comparing wt\% total solids only. 
The statistical experimental design for the resuspension test required six samples from each of the six sampling locations. The samples were drawn from the tank in a random order using the tank sampler (see Section 5.3 for a description of the tank sampler). The sampling order is summarized in Tables A. 4 through A. 6 of Appendix A. The resuspension tests were performed after completion of the homogeneity/sampling system tests for each slurry concentration. It took approximately 1 hour to take 36 samples. 
$\vdots$ 


\subsection{TEST EQUIPMENT}

The equipment used included the MFHT at West Valley, a mechanical liquid-sampling system, a bottle-and-rod tank sampler, a Haake viscometer, and a bench-scale mixing system. This section describes the major equipment used for the mixing studies.

\subsection{WEST VALLEY MELTER FEED HOLD TANK}

The MFHT is used to feed the radioactive liquid waste and glass formers slurry (melter feed) to the ceramic melter. A schematic of the tank is depicted in Figure 5.1.

The stainless steel tank is $10 \mathrm{ft}$ in diameter and approximately $10 \mathrm{ft}$ high. Its capacity is 5,000 gallons. The MFHT is equipped with an agitator, four equally spaced standard baffles, heating coils, and a cooling jacket. The heating coils are positioned inside the tank near the tank wall.

The agitator mixes the slurry in the MFHT to assure a homogeneous mixture is fed to the ceramic melter. In addition, the agitator must resuspend the melter feed that has settled to the bottom of the tank during an unscheduled power failure. The agitator motor is $15 \mathrm{Hp}$, single speed (155 rpm), with a 460 volt, 3-phase DC drive. The agitator is equipped with two 36-in.dia., high-efficiency turbine impellers. Each impeller has three blades (see Figure 5.1).

\subsection{MECHANICAL LIQUID-SAMPLING SYSTEM}

The purpose of the 1 iquid-sampling system is to obtain a representative sample of melter feed from the MFHT. During actual melter operations, the sample will be used to qualify the glass for disposal in a repository. The liquid-sampling system consists of two major pieces of equipment: 1) the ADS pump, and 2) the Hydragard Series $2000^{\circledR}$ liquid sampler.

() Registered tradename of Hinds International, Inc., Hillsboro, Oregon. 


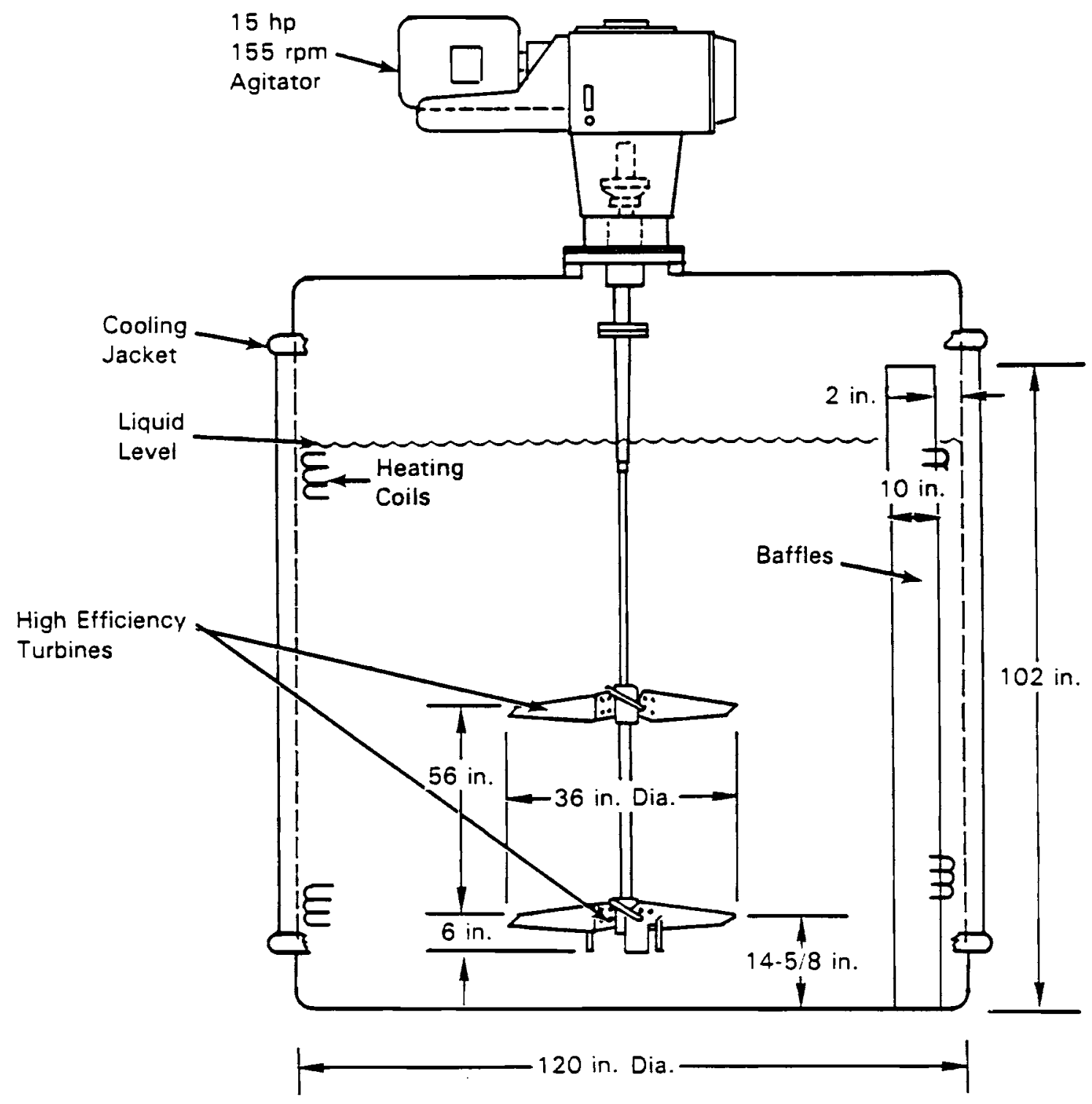

$38806-152.004$

FIGURE 5.1. Schematic of West Valley Melter Feed Hold Tank

For the tests described here, the piping between the ADS pump and liquid sampler did not exactly duplicate the arrangement that will be used in the actual system. Half-inch tubing with a 1/16-in. wall thickness was used for 4/5 the distance between the ADS pump and the Hydragard sampler. Approximately $5 \mathrm{ft}$ before the sampler, the tubing widened to the $3 / 4$-in. tubing (approximately 0.5-in. inside dia.) specified by the sampler manufacturer. 
Line sizes and fittings were not replicated, and the sample bottles used with the Hydragard sampler were considerably different from those that are planned for use in the actual system. Therefore, results from the sampling system tests described in this report may not be representative of results from the actual sampling system.

\subsubsection{Air-Displacement Slurry Pump}

The basic operating sequence for the ADS pump is portrayed in Figure 5.2. The entire operating cycle can be described by a series of four steps. The first step positions the valve open, while the second step allows the chamber to fill with the liquid slurry. The third step positions the

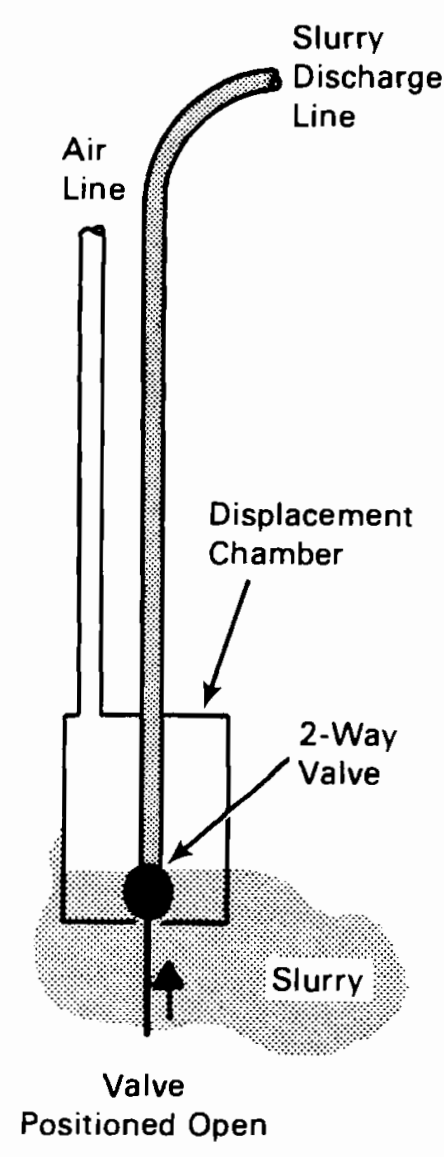

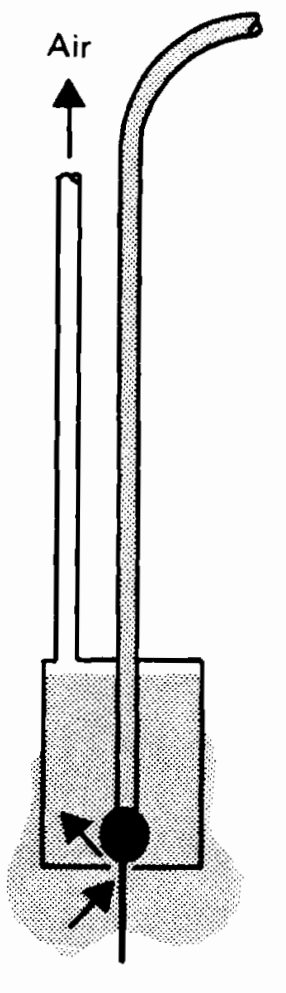

Slurry Enters Chamber

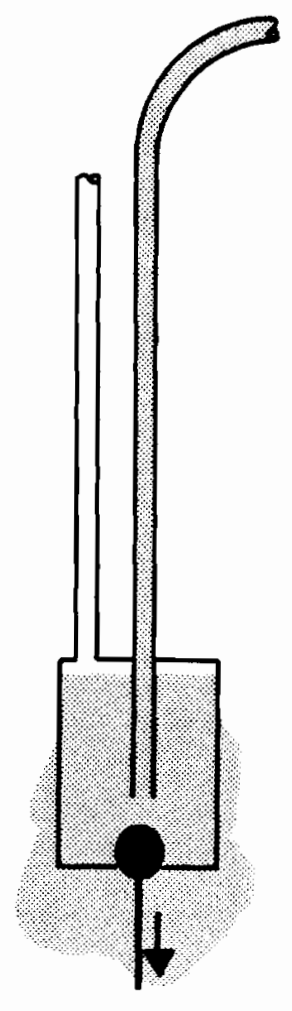

Positioned Closed

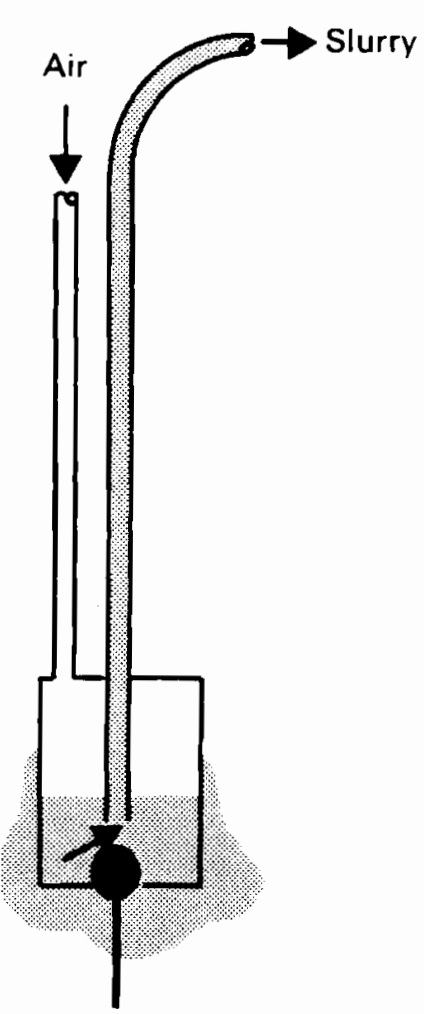

Slurry Discharged

FIGURE 5.2. Operating Cycles of ADS Pump 
valve closed. The fourth step is the discharge step, where compressed air is valved into the chamber, thus forcing the slurry out the discharge 7 ine. The air can be described as a reciprocating piston. By controlling the air pressure and cycle time, the flow rate can be controlled. This cycle creates a pulsating flow.

The slurry pump should be capable of pumping the melter feed in the turbulent flow regime, which should prevent solids from settling in the piping and either plugging the line and/or not providing a representative sample to the in-line liquid sampler. The ADS pump is capable of pumping the melter feed slurry at flow rates between 50 and $250 \mathrm{~L} / \mathrm{hr}$. The cycle times for these flow rates are 100 and 25 seconds, respectively. For the tests in this study, the cycle time and air pressure were adjusted for an average flow rate of $250 \mathrm{~L} / \mathrm{hr}$. This flow rate corresponds to an average velocity of $1.8 \mathrm{ft} / \mathrm{s}$ for a pipe with a $0.5-$ in. inside diameter.

\subsubsection{Hydragard Series 2000 Liquid Sampler}

The Hydragard sampler (Figure 5.3) was developed for the Savannah River Laboratory and is designed to provide positive extraction and collection of samples from in-line process flows that are toxic, radioactive, or chemically severe. The sampler is a manually activated, closed loop system for use with robotic systems.

The sample bottles allow flow to recirculate in the bottle. Figure 5.4 shows two sample bottle designs. The bottle on the right was used in the tests discussed in this report, and the bottle on the left is the design currently planned for actual operations. When the bottle is removed from the concentric needle filler subassembly [item (3) on Figure 5.3], a doublelayered septum in the cap cleans the dip tubes. This procedure prevents radioactive waste from dripping onto the sample shroud.

\subsection{BOTTLE-AND-ROD TANK SAMPLER}

The tank sampler (Figure 5.5) was used to obtain slurry samples at six locations in the MFHT. This type of sampler is called the bottle-and-rod sampling system. Three $60-\mathrm{ml}$ polyethylene bottles were secured to the long pole at locations corresponding to the specified sampling depths within the 


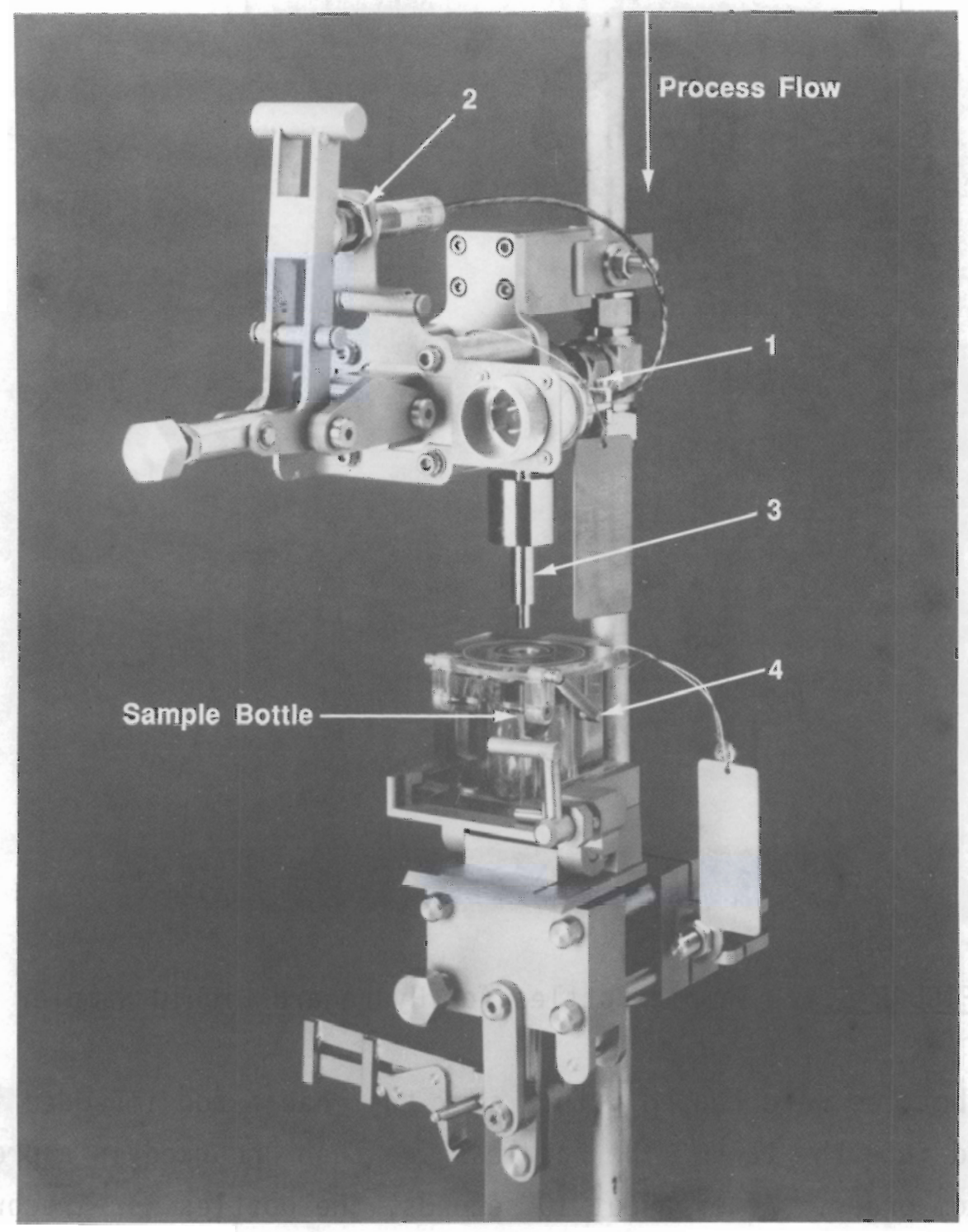

(1) Sampler Subassembly - Extracts sample from process line on operator or robot command.

(2) Limit Switch Subassembly - Provides system status verification signals for the valve "open" and "closed" positions.

(3) Concentric Needle Filler Subassembly - Transfers the sample to the sample container and returns excess sample to the process flow.

(4) Sample Container Shroud Subassembly - Positions and protects the sample container in the sampling system, and pravides a backup containment seal in the event of failure of the primary seal between the concentric needle filler and the sample container. Standard material of construction is optically clear polycarbonate.

FIGURE 5.3. Hydragard Series 2000 Liquid-Sampler 

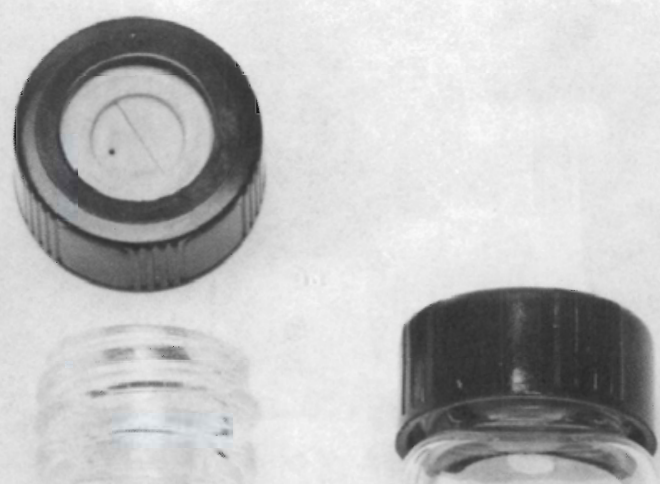

\section{FIGURE 5.4. Sample Bottles for Hydragard Liquid-Sampler}

tank. The bottles were capped with a cork that had a rod imbedded in it, and then lowered into the tank. The bottles were then uncorked in a predetermined, random order. After about 10 seconds, the bottles were recorked.

This tank sampler design was chosen because it is simple and fundamentally different from the liquid-sampling system. The liquid-sampling system consists of a pipeline from the ADS pump to the sampler, and solids could settle in that line and/or in the sample bottle. The tank sampler collects samples directly from the tank. Comparing data from the two sampling systems provided information on possible deficiencies associated with the ADS pump/ Hydragard sampling system. Section 6.3 discusses the results from the sampling system study. 


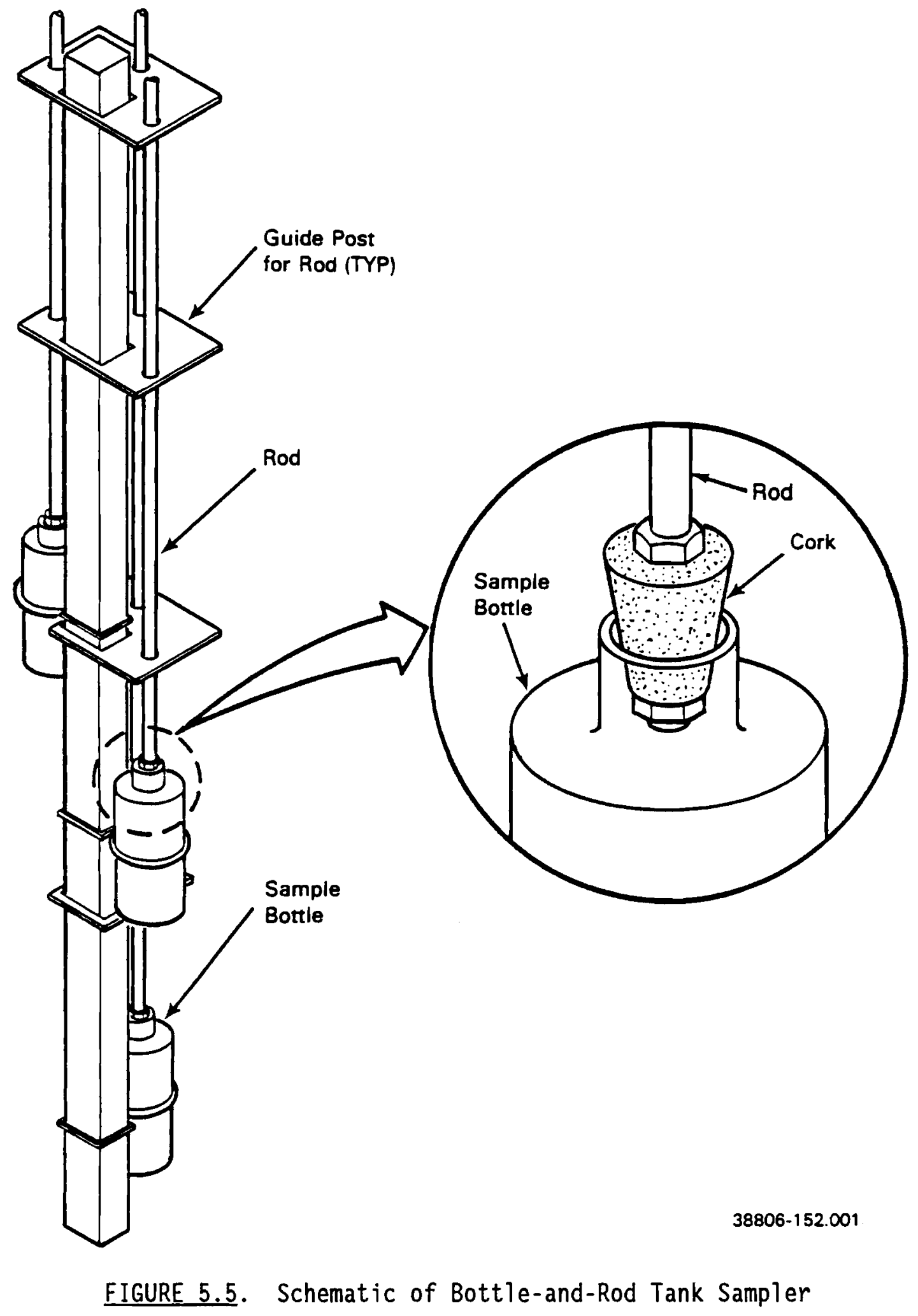




\subsection{HAAKE VISCOMETER}

Laboratory rheological data were obtained with a Haake Rotovisco ${ }^{\circledR}$ viscometer equipped with an M150 measuring/drive head and the NV sensor system. To measure rheological properties using this instrument, the sample must be placed into the gap between two coaxial cylinders. A motor drives the inner cylinder. A viscosity-related torque, caused by the resistance of the sample to shearing, acts on the inner cylinder. This torque deflects a measuring spring placed between the motor and the inner cylinder. The magnitude of the spring deflection correlates linearly with the torque. The spring deflection is transformed into an electrical signal. The torque and tachometer signals are recorded.

The speed signal required for determining shear rate does not come from the rotor directly but from the tacho-generator that sits above the motor. The tacho-generator is mechanically linked to the motor. For slurries that do not exhibit yield stresses, the speeds of the tacho-generator, motor, and rotor are identical so that the speed signal also defines the rotor speed. A slurry with a yield stress will clamp the rotor to the cup until the applied torque is greater than the yield stress.

While the rotor is still clamped and at a standstill, the motor rotation will cause some spring deflection and consequently a torque signal on the ordinate. For a slurry with a yield stress, a straight line, leaning off the vertical with an angle $(\beta)$, is recorded initially (Figure 5.6). When the shear stress surpasses the yield value, the rotor breaks loose from its clamp and picks up speed, accelerating almost instantaneously to the signal speed. The change in the behavior of the sample becomes apparent in the rapid turn of the flow curve. The ordinate value of this turning point defines the yield value.

( $\quad$ Registered tradename of Haake Buchler Instruments, Inc., Saddlebrook, New Jersey. 


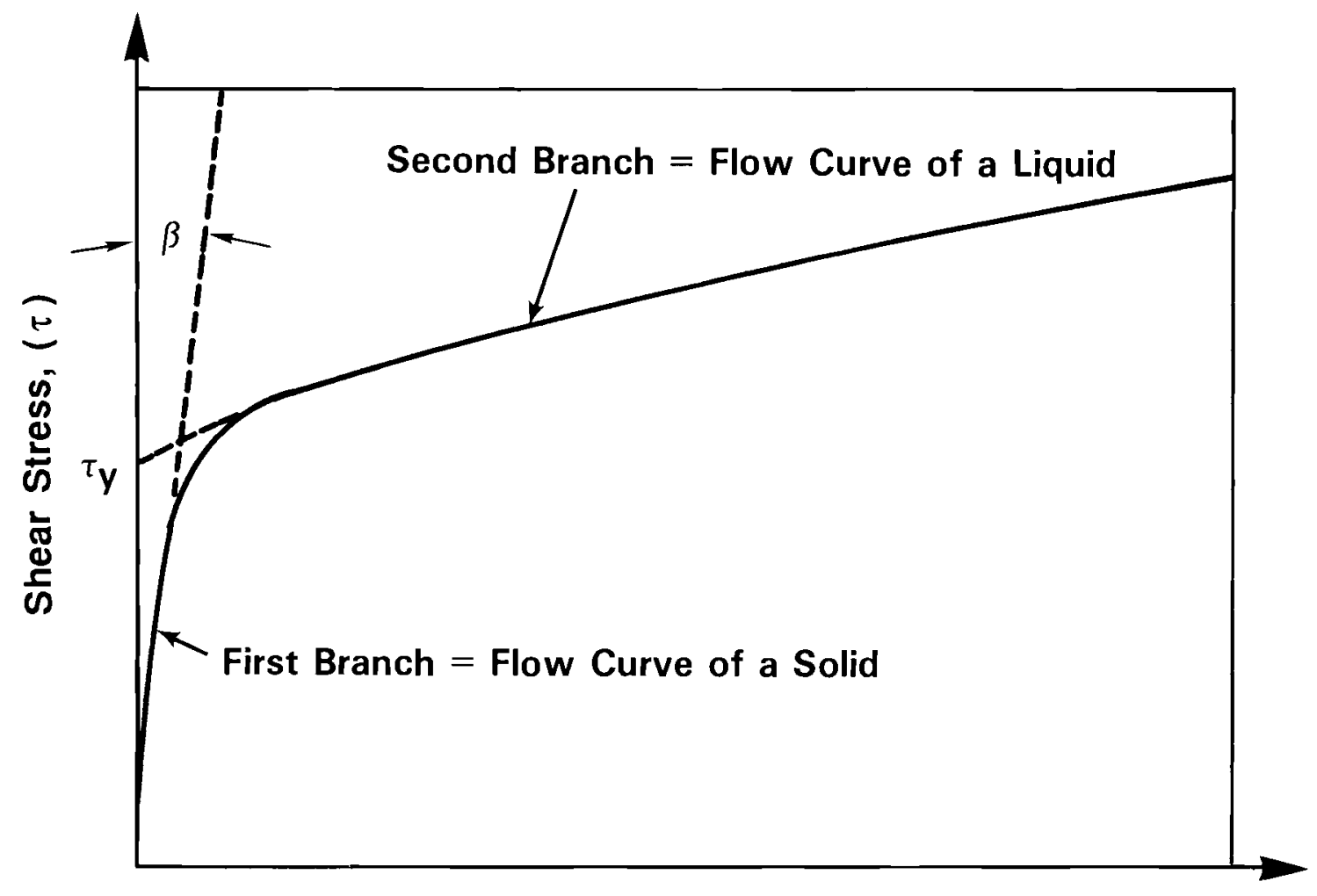

Shear Rate $(d v / d y)$, sec ${ }^{-1}$

FIGURE 5.6. Flow Curve (Rheogram) for a Yield-Pseudoplastic Fluid

\subsection{BENCH-SCALE MIXING SYSTEM}

The bench-scale mixing system was used by PNL in 1986 to examine the effects of significant independent variables on the distribution of solids in several types of mixing systems, and provide a rational basis for the design of full-scale mixing systems (Peterson, McCarthy and Muhlstein 1986). One of the mixing systems evaluated was the West Valley MFHT.

The bench-scale system (Figure 5.7) was comprised of a 15-in.-dia., 11-gal, clear plastic tank equipped with removable baffles, heating coils, and impellers. The agitator was driven by a $0.25 \mathrm{Hp}, 0-1100 \mathrm{rpm}, \mathrm{AC}$ motor. The assembly was supported on "frictionless" bearings to facilitate the measurement of the torque applied to the slurry in the tank. A load cell connected to a 10-in. lever arm measured this applied torque.

The West Valley MFHT mixing system was not designed at the time the bench-scale tests were conducted. Therefore, it was assumed that the West Valley system would have two impellers--a 4-blade flat turbine for the lower 


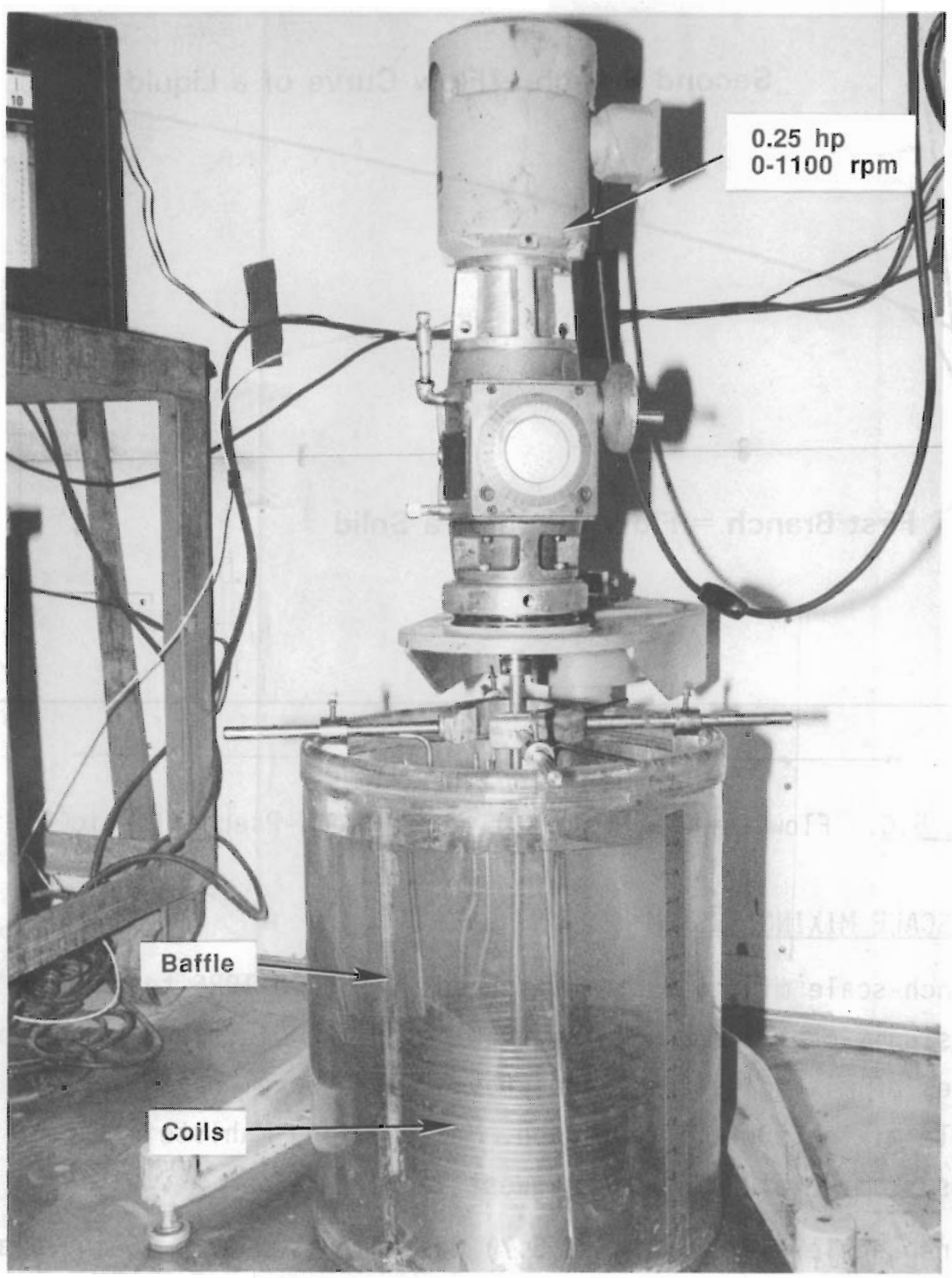

FIGURE 5.7. Bench-Scale Mixing System 
impeller and a high efficiency turbine for the upper impeller. The impellers are shown in Figure 5.8. A comparison of the geometric similarity between the two systems is presented in Table 6.10.

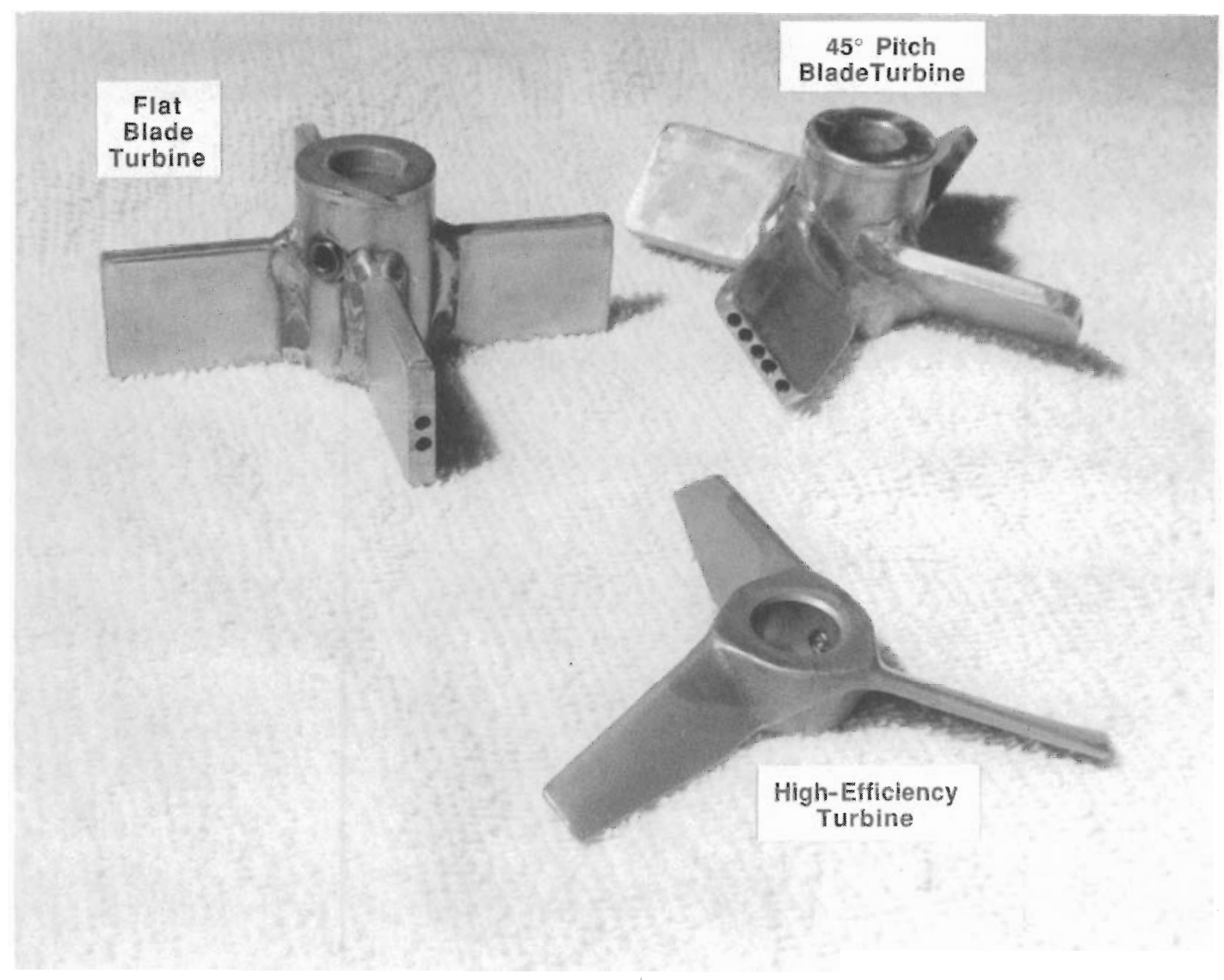

FIGURE 5.8. Bench-Scale Impellers 


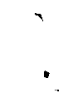




\subsection{EXPERIMENTAL RESULTS AND DISCUSSION}

The homogeneity/sampling system and resuspension tests were designed to permit a sound statistical analysis of the data. The objectives of the statistical design were to determine whether an adequately homogeneous slurry is obtained in the MFHT, and whether the liquid-sampling system provides a representative sample of the melter feed.

Homogeneity of the feed slurry was quantified by comparing the size of the differences between the average weight percent total solids, or elemental weight percents, across the six sample locations within the tank. If a significant difference existed between any of the six averages, the melter feed slurry was considered nonhomogeneous. The liquid-sampling system was determined to provide a representative sample if an insignificant difference existed between the average weight percent solids, or elemental weight percents, of its sample and the average of those samples obtained from the six sample locations.

Waste samples were sent to PNL for physical and rheological characterization. Results from those analyses are presented in Section 6.1. The statistical analysis of the data received from West Valley is described in Section 6.2. Results of the data analyses for the homogeneity/sampling system tests and the resuspension tests are presented in Sections 6.3 and 6.4 , respectively. Graphs of the results from the statistical analyses are presented in Appendix B. During analysis of the data, effects from the analytical instrumentation and procedures were observed. These effects are explained in Section 6.5. In addition, Section 6.5 discusses ways to decrease the error associated with these effects. Section 6.6 discusses the verification of the bench-scale mixing studies.

\subsection{WASTE CHARACTERIZATION}

An extra sample from each sampling location was taken during the homogeneity/sampling system tests and sent to PNL. The samples from each slurry concentration were combined, and physical and rheological analyses were performed on the combined samples. These evaluations provided the background 
information needed to verify the scale-up of the bench-scale data, and determine if the slurry was pumped through the liquid-sampling system in the turbulent flow regime.

\subsubsection{Physical Properties}

The density, weight percent total solids, and elemental weight percents (ICP analysis) of the combined samples were measured at PNL. Table 6.1 presents a summary of the results. The numbers resulting from the analyses conducted at West Valley are included in the table for comparison, as are the properties of the slurry used in the bench-scale mixing study performed at PNL in FY 1986.

The density of the combined reference slurry was similar to the density of the slurry used in the bench-scale studies (1.29 as compared to $1.26 \mathrm{gr} / \mathrm{ml}$ for the bench-scale work). The PNL measurements of weight percent solids were lower than the measurements obtained at West Valley and higher than the measurements of the slurry used for the bench-scale tests. The weight percent solids of the bench-scale slurry was $36.5 \mathrm{wt} \%$, the combined reference sample was $41.8 \mathrm{wt} \%$, and the average of al1 the reference melter feed slurry samples was $44.4 \mathrm{wt} \%$.

\subsubsection{Rheological Properties}

Laboratory evaluations using the Haake viscometer were conducted to determine the effects of shear rate on the apparent viscosity of the slurries

TABLE 6.1. Physical Properties of Melter Feed Slurries Melter Feed Slurry Concentration

\begin{tabular}{|c|c|c|c|c|c|c|c|}
\hline \multirow[b]{2}{*}{ roperty } & \multicolumn{2}{|c|}{ Concentrated } & \multicolumn{3}{|c|}{ Reference } & \multicolumn{2}{|c|}{ Dilute } \\
\hline & PNL (a) & WV (5) & PNL & $B-S(C)$ & WV & PNL & WV \\
\hline 0 & 1.40 & $\mathrm{NE}(\mathrm{d})$ & 1.29 & 1.26 & NE & 1.25 & NE \\
\hline Total solids, & 46.0 & 51.1 & 41.8 & 36.5 & 44.4 & 33.9 & 36.1 \\
\hline
\end{tabular}

(a) Properties of the combined samples measured at PNL.

(b) Averages of a 11 the samples analyzed at West Valley.

(c) Properties of simulated West Valley melter feed used in the bench-scale mixing study performed at PNL (Peterson, McCarthy and Muhlstein 1986).

(d) $\mathrm{NE}=$ not evaluated. 
tested. The rheogram (plot of shear stress versus shear rate) for each slurry is presented in Figures 6.1 through 6.3. These plots indicate that the reference and dilute melter slurries are Newtonian fluids and the concentrated melter slurry is a non-Newtonian, yield-pseudoplastic fluid. Viscosity of the reference and dilute slurries is about 3.1 and $2.7 \mathrm{cP}$,

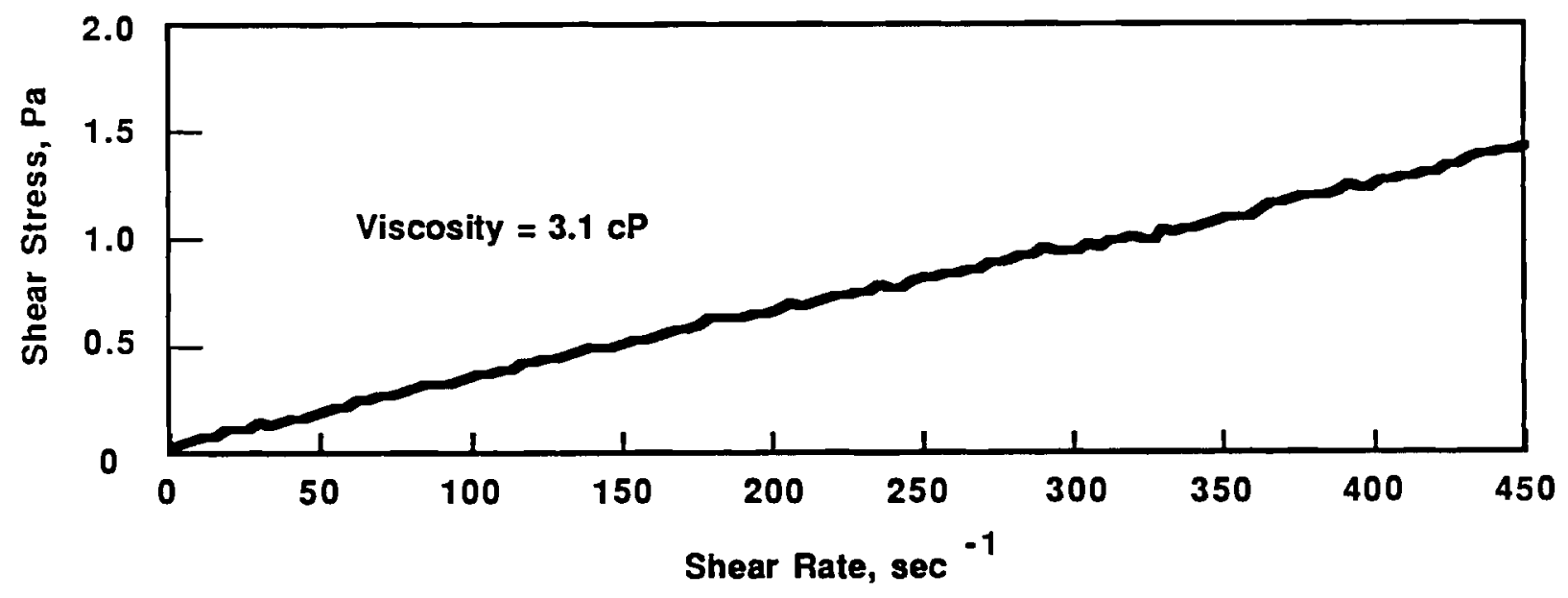

$38807138.1 M$

FIGURE 6.1. Rheogram of Combined Sample of the Reference Melter Feed Slurry

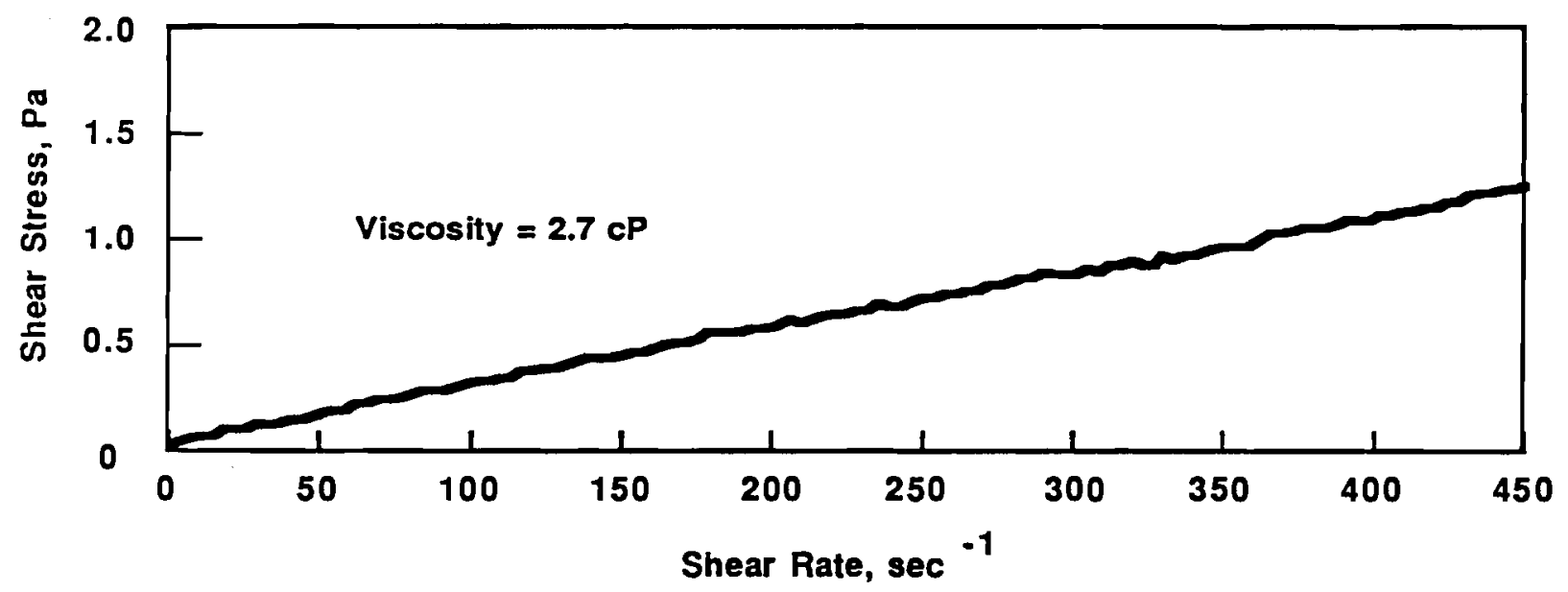

$38807138.2 M$

FIGURE 6.2. Rheogram of Combined Sample of the Dilute Melter Feed Slurry 


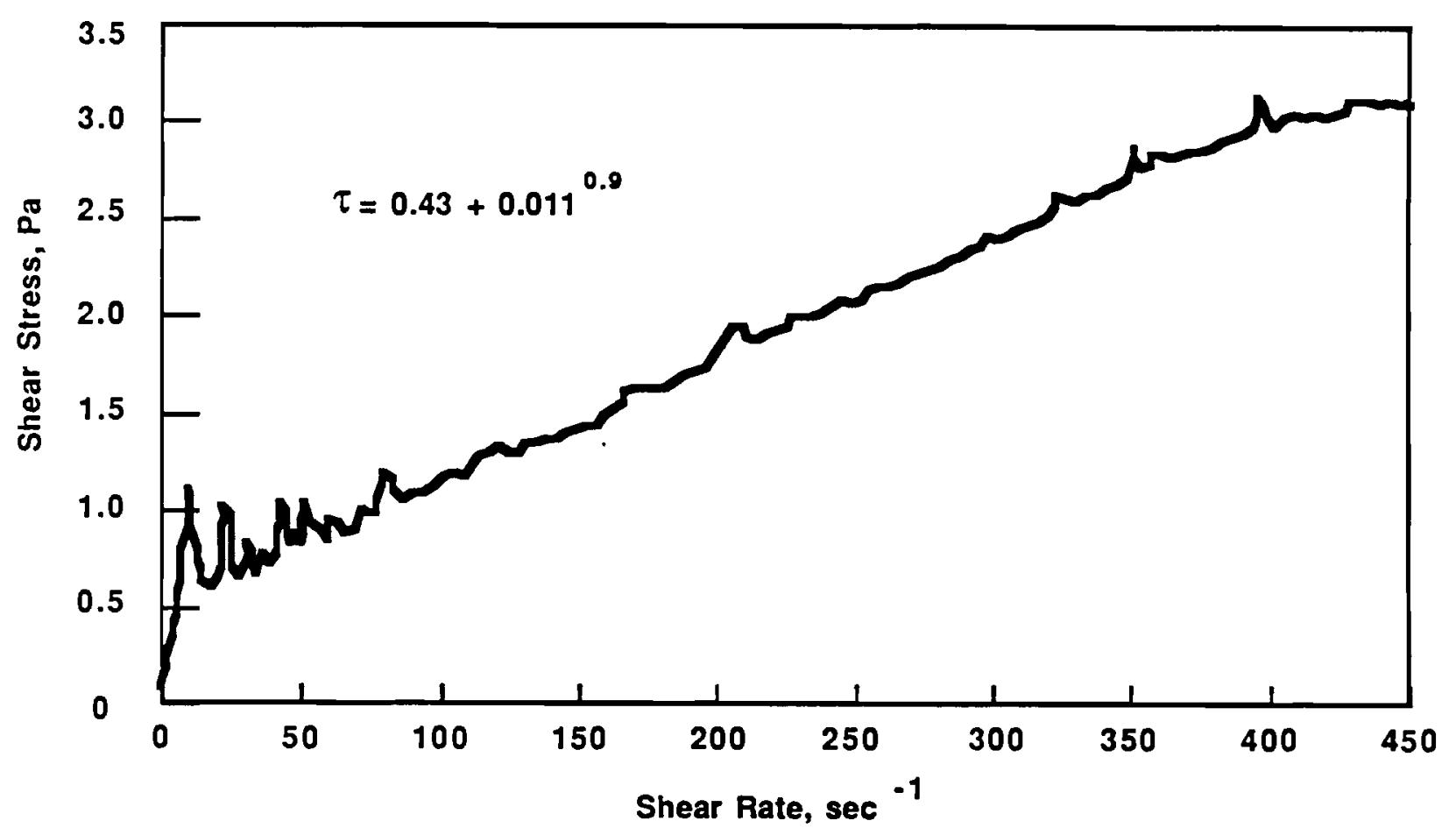

$38807138.3 M$

FIGURE 6.3. Rheogram of Combined Sample of the Concentrated Melter Feed Slurry

respectively. The viscosity of the concentrated melter slurry is a function of the shear rate. For a shear rate of $30 \mathrm{~s}^{-1}$ [the average shear rate in the mixing tank (Section 3.1)], the viscosity of the concentrated melter feed slurry is $22 \mathrm{CP}$.

The rheological data discussed above was used to verify the bench-scale data and determine if the slurries were pumped through the sampling system in the turbulent flow regime. Verification of bench-scale data is discussed in Section 6.6. Rheological data, as it pertains to pumping fluid in a pipe, is discussed in this section.

A Newtonian analysis was used to determine the transport properties of the reference and dilute slurries, and a non-Newtonian model (Hanks 1978) was used to analyze the concentrated slurry. Results from those calculations are summarized in Table 6.2. Reynolds numbers of 2900 and 3225 were calculated for the reference and dilute melter feed slurries, respectively, for a 
TABLE 6.2. Rheological and Transport Properties of Combined Melter Feed Samples for Slurry Sampling System

\begin{tabular}{l} 
Property \\
\hline Classification \\
Critical Reynolds No. \\
Reynolds No. at $1.8 \mathrm{ft} / \mathrm{s}$ \\
Critical velocity, $\mathrm{ft} / \mathrm{s}$ \\
Design velocity, $\mathrm{ft} / \mathrm{s}(\mathrm{a})$ \\
Actual velocity, $\mathrm{ft} / \mathrm{s}$ \\
Flow regime $(\mathrm{b})$
\end{tabular}

\begin{tabular}{|c|c|c|}
\hline $\begin{array}{c}\text { Melter reec } \\
\text { Concentrated }\end{array}$ & $\begin{array}{l}\text { Durry concen } \\
\text { Reference }\end{array}$ & $\frac{t \text { tron }}{\text { Dilute }}$ \\
\hline Yield-Pseudoplastic & Newtonian & Newtonian \\
\hline 2600 & 2100 & 2100 \\
\hline 1550 & 2900 & 3225 \\
\hline 2.9 & 1.3 & 1.2 \\
\hline 3.9 & 2.5 & 2.3 \\
\hline $\begin{array}{c}1.8 \\
\text { Laminar }\end{array}$ & $\begin{array}{c}1.8 \\
\text { Transitional }\end{array}$ & $\begin{array}{c}1.8 \\
\text { Transitional }\end{array}$ \\
\hline
\end{tabular}
(a) Design velocity for non-Newtonian slurries is defined as the critical velocity $+1 \mathrm{ft} / \mathrm{s}$ (Ande et al. 1971). For Newtonian slurries, the design velocity is the velocity that corresponds to a Reynolds number of 4000 .
(b) Turbulent flow regime begins at design velocity. If actual velocity is less than design velocity, flow is either laminar or transitional. If velocity is below design velocity and Reynolds number is below critical Reynolds number, then flow is laminar.

0.5 -in.-(inside)-dia. pipe and an average velocity of $1.8 \mathrm{ft} / \mathrm{s}$. These values are slightly above the Newtonian critical Reynolds number for circular pipes (i.e., 2100).

Results from the non-Newtonian analysis of the concentrated melter feed slurry indicated a critical Reynolds numbers of 2600 and a critical velocity of $2.9 \mathrm{ft} / \mathrm{s}$ in a 0.5-in.-(inside) dia.-pipe. The concentrated melter feed slurry was pumped at $1.8 \mathrm{ft} / \mathrm{s}$. This velocity is well below the critical velocity, indicating that the slurry was likely in the laminar flow regime. General practice for designing pipelines for non-Newtonian slurry transport suggests pumping the slurry at velocities exceeding the critical velocity by at least $1 \mathrm{ft} / \mathrm{s}$ to prevent solids from settling (Ande et al. 1971).

The combined sample of the reference melter feed slurry was slightly different rheologically from the melter feed slurry used in the bench-scale tests. The bench-scale slurry was considered a yield-pseudoplastic fluid with a yield stress of $0.22 \mathrm{~Pa}$, a consistency index of $0.0051 \mathrm{~Pa}-\mathrm{s}$, and a flow behavior index of 0.979 (Peterson, McCarthy and Muhlstein 1986). As 
stated earlier, the combined reference melter slurry was considered a Newtonian fluid. The viscosity of the bench-scale and reference melter feed slurries is approximately 8 and $3.2 \mathrm{CP}$, respectively. The bench-scale melter feed slurry exhibited behavior similar to the concentrated melter feed slurry. The scale-up of bench-scale data was evaluated for all three slurry concentrations.

\subsection{STATISTICAL ANALYSIS OF THE DATA}

The sample and analysis orders were completely random, with two exceptions. The sample and analysis order over slurry concentrations for both types of tests was not random. All samples of the concentrated slurry were obtained and analyzed first, followed by the dilute samples and finally the reference samples. This restriction causes any comparison between the slurry concentrations to be confounded with a comparison across time. However, because the comparisons between slurries are not of major interest, confounding slurry effects with time does not have a significant impact.

Sample and analysis order for the resuspension tests was not completely randomized over the slurry and sampling times (referred to as wait-time). The analysis order was randomized between the 2- and 6-hr wait-time samples; however, the 24-hr wait-time samples were all analyzed after the 2- and 6-hr samples. The effect of these restrictions will be discussed in greater detail in Section 6.4. The sampling order for each test is presented in Tables A.1 through A.6 in Appendix A, and the analysis order for each sample is presented in Tables A.7 through A.12.

Both as-analyzed elemental weight percents and normalized elemental oxide weight percents were available from West Valley for the samples obtained from the homogeneity/sampling system tests. The normalized elemental oxide weight percents were determined by first assuming an oxide form for each element, then dividing the oxide weight percent of one elemental oxide by the sum of all the elemental oxide weight percents. As a result, the normalized weight percents sum to $100 \%$. 


$$
c_{n}=\frac{c_{i}}{\Sigma C_{i}}
$$

where $C_{n}=$ normalized elemental oxide weight percent

$C_{i}=$ assumed elemental oxide weight percent

$\Sigma C_{i}=$ sum of the elemental oxide weight percents

The sum of the oxide weight percents, $\Sigma C_{j}$, is a random variable that is dependent on each elemental as-analyzed weight percent.

A preliminary analysis showed that the effects of the sampling system and location differences for some of the elements were masked by the "noise" added to the as-analyzed values through normalization. Therefore, the asanalyzed values were used in the statistical analyses to determine the statistical significance of those effects.

Although the as-analyzed results show that some effects are statistically significant, practical significance is probably best determined by examining the effect on the normalized oxide results. This is because the acceptance criteria for the feed composition will probably be in terms of the normalized oxide weight percents (i.e., silicon dioxide must be within $\pm 8 \%$ of the target normalized oxide weight percent). Practical significance versus statistical significance will be discussed further.

In the discussion that follows, a 95\% confidence level was assumed for defining statistical significance. A marginal significance was noted when effects were significant at the $90 \%$ confidence leve1. Al1 statistical analyses and manipulations were conducted using $S A S^{\circledR}$, a statistical software program. The results of the statistical analyses of the homogeneity/sampling system test data are discussed in Section 6.3. The results of the resuspension tests are discussed in Section 6.4.

\subsection{HOMOGENEITY/SAMPLING SYSTEM TESTS}

The homogeneity/sampling system tests were performed to characterize the melter feed system at West Valley and verify the scale-up of the bench-scale

() Registered tradename of SAS Institute, Inc., Cary, North Carolina. 
mixing studies performed at PNL. Results of scale-up verification are presented in Section 6.6. The characterization of the melter feed system included quantifying the homogeneity of the melter feed and determining if the liquid-sampling system obtains representative samples of the slurry.

Elemental weight percent determinations were available for 25 elements, in addition to the determinations of weight percent total solids. Seven of the 25 elementals were used in the statistical analyses (Al, B, Ca, Fe, Li, $\mathrm{Na}, \mathrm{Si}$ ). These oxides were chosen because they are the major soluble and insoluble constituents in the melter feed slurry.

Preliminary analyses showed that the analytical uncertainty for several of the elemental determinations was not the same across the three concentrations of slurry. Discussions with West Valley analytical staff indicated that the dilute feed was "sticky" and more difficult to suspend. Eventually, a stirring rod was used to break precipitates off the sample container wall before shaking the container to obtain a homogeneous, representative aliquot. The concentrated and reference melter feed slurries did not require the use of a stirring rod. In addition, it appears that the analytical laboratory methods or instrumentation may have provided sources of uncertainty that affect the long-term accuracy of the measurement. This long-term analytical effect is discussed in greater detail in Section 6.5. Because the replicate variations are different for each slurry concentration, a separate statistical analysis was conducted for each concentration.

Several outlying observations were observed through graphical portrayals and deleted from the statistical analysis. The graphs of the weight percent total solids and each element versus analytical order are presented in Appen$\operatorname{dix}$ B. The outliers that were deleted are listed in Table 6.3. Several samples appeared to be outliers for nearly all of the elemental constituents, while others were outliers for only one of the constituents. Other outliers (mostly typographical errors) were detected, corrected, and incorporated into the statistical analysis.

The statistical analysis technique of Analysis of Variance (ANOVA) was used to examine the homogeneity of the MFHT and the representativeness of the samples obtained using the mechanical liquid-sampling system. Because there 
IABLE 6.3. Outliers That Were Deleted from All Statistical Analyses

\begin{tabular}{|c|c|c|c|}
\hline As-Analyzed & Elements Deleted & Normalized & $\begin{array}{l}\text { Elements } \\
\text { Deleted }\end{array}$ \\
\hline $041-$ CON-021 ${ }^{(a)}$ & $\mathrm{Ca}$ & $022-\operatorname{CON}-153$ & $\mathrm{Na}$ \\
\hline $086-C O N-124$ & ALL & $041-$ CON-021 & $\mathrm{Ca}$ \\
\hline 016-REF-078 & $\mathrm{Na}$ & $100-\operatorname{CON}-147$ & ALL \\
\hline $027-R E F-154$ & $\mathrm{Ca}$ & $106-$ CON-029 & ALL \\
\hline 076-REF-097 & ALL, TOTAL SOLIDS & $115-\operatorname{CON}-158$ & $\mathrm{Na}$ \\
\hline $086-$ REF-127 & ALL & $140-\operatorname{CON}-146$ & ALL \\
\hline 116-REF-082 & $\mathrm{Na}$ & $142-\mathrm{CON}-156$ & $\mathrm{Na}$ \\
\hline 022-DIL-090 & TOTAL SOLIDS & $145-$ CON- 162 & $\mathrm{Na}$ \\
\hline $027-D I L-148$ & TOTAL SOLIDS & $148-\operatorname{CON}-159$ & $\mathrm{Na}$ \\
\hline 040-DIL-107 & TOTAL SOLIDS & $027-$ REF-154 & $\mathrm{Ca}$ \\
\hline 073-DIL-136 & ALL, TOTAL SOLIDS & 074-REF-097 & ALL \\
\hline 094-DIL-109 & ALL & 116-REF-082 & $\mathrm{Al}$ \\
\hline \multirow[t]{11}{*}{ 129-DIL-132 } & ALL & $X X X-D I L-<007^{(b)}$ & $\mathrm{Ca}$ \\
\hline & & 017-DIL-008 & $\mathrm{Ca}$ \\
\hline & & 062-DIL-078 & $\mathrm{A} 1$ \\
\hline & & 073-DIL-136 & ALL \\
\hline & & 083-DIL-077 & A1 \\
\hline & & 094-DIL-109 & ALL \\
\hline & & $100-D I L-079$ & Al \\
\hline & & 114-DIL-046 & ALL \\
\hline & & 129-DIL-132 & $\mathrm{Li}$ \\
\hline & & $130-D I L-084$ & $\mathrm{Fe}$ \\
\hline & & 140-DIL-047 & ALL \\
\hline
\end{tabular}

(a) The first three numbers indicate the order the sample was taken, the next three letters indicate the concentration of the slurry (REF = reference, $C O N=$ concentrated, and $D I L=$ dilute melter feed slurry), and the final three numbers indicate the order the sample was analyzed.

(b) Calcium data from the first seven dilute samples that were analyzed were deleted from all statistical analyses. 
were several measured responses per sample (several elemental constituents and a total solids measurement), a multivariate ANOVA plus the usual univariate ANOVAs was used. The ANOVA computational technique has been fully described in Box, Hunter, and Hunter (1978). The multivariate technique accounts for the correlative structure that exists between the elemental determinations, and performs a simultaneous examination of the seven constituents.

The results of the statistical analyses for the homogeneity/sampling system tests are summarized in Table 6.4. The average elemental weight percents and total solids at the different locations in the MFHT were not significantly different from one another, as indicated in Table 6.4 by statistically insignificant values for the nonhomogeneous standard deviations. Thus, the MFHT appears to be homogeneous for the three concentrations of slurry tested. The analytical variation appears to be the major source of uncertainty. Efforts to reduce the variability of the apparent tank contents should focus on improving the analytical precision rather than improving tank homogeneity.

Elemental weight percent analyses of the concentrated melter feed samples from the liquid-sampling system showed a significant difference from the other samples for $A 1, B, F e$, and possibly $\mathrm{Si}$. The sampler bias is quantified in Table 6.5. The bias is defined as the difference between the mean of the liquid-sampling system (sampler) samples and the tank samples. The relative bias (Column 2) is defined as the bias divided by the average weight percents.

The sampler bias was not statistically significant for the $\mathrm{Ca}, \mathrm{Li}, \mathrm{Na}$, and total solids determinations for the concentrated slurry. (The calcium data appeared to be erroneous for the concentrated slurry, as shown by the plot of calcium determinations by analytical order in Figure B.3 of Appendix $B$. Thus, the calcium data is considered unreliable only for the concentrated slurry.) For the dilute and reference slurries, the sampler bias was statistically significant for $\mathrm{Al}, \mathrm{B}, \mathrm{Ca}, \mathrm{Fe}, \mathrm{Si}$, and total solids. However, there was no significant sampler bias for the $\mathrm{Li}$ or Na results. The sampler 
TABLE 6.4. Estimates of the Inhomogeneity and Analytical Variations Using the As-Analyzed Data

\begin{tabular}{|c|c|c|c|c|c|c|c|c|c|c|c|c|c|c|c|}
\hline \multirow[b]{2}{*}{ Element } & \multicolumn{5}{|c|}{ Concentrated Slurry } & \multicolumn{5}{|c|}{ Reference } & \multicolumn{5}{|c|}{ Dilute } \\
\hline & $\begin{array}{c}\text { Mean }_{\mathrm{Wt}}(\mathrm{a}) \\
\end{array}$ & $\begin{array}{l}\text { Inhomo-(b) } \\
\text { geneity, } \\
\text { std. Dev. }\end{array}$ & $\begin{array}{l}\text { Ana-(c) } \\
\text { (ytical, } \\
\text { std. Dev. }\end{array}$ & $\begin{array}{l}\text { Inhamo- } \\
\text { geneity, } \\
\text { RSD, \% }\end{array}$ & $\begin{array}{l}\text { Ana- } \\
\text { lytical, } \\
\text { RSD, \% } \\
\end{array}$ & $\begin{array}{l}\text { Mean, } \\
\text { wt\% }\end{array}$ & $\begin{array}{l}\text { Inhomo- } \\
\text { geneity, } \\
\text { Std. Dev. }\end{array}$ & $\begin{array}{c}\text { Ana- } \\
\text { lytical, } \\
\text { Std. Dev. }\end{array}$ & $\begin{array}{l}\text { Inhomo- } \\
\text { geneity, } \\
\text { RSD \% }\end{array}$ & $\begin{array}{r}\text { Ana- } \\
\text { lytical, } \\
\text { RSD, z } \\
\end{array}$ & $\begin{array}{l}\text { Mean, } \\
\text { wt\% }\end{array}$ & $\begin{array}{r}\text { Inhomo- } \\
\text { geneity, } \\
\text { std. Dev. }\end{array}$ & $\begin{array}{c}\begin{array}{c}\text { Ana- } \\
\text { lytical, } \\
\text { Std. Dev. }\end{array} \\
\end{array}$ & $\begin{array}{r}\text { Inhomo- } \\
\text { geneity, } \\
\text { RSD, } 8 \\
\end{array}$ & $\begin{array}{r}\text { Ana- } \\
\text { Itical, } \\
\text { RSD, \% } \\
\end{array}$ \\
\hline $\begin{array}{l}\text { Total } \\
\text { Sol ids }\end{array}$ & 51.1 & 0 & 0.71 & 0 & 1.4 & 44.4 & 0 & 1.08 & $\mathbf{0}$ & 2.4 & 36.1 & $\mathbf{0}$ & 0.73 & $\mathbf{0}$ & 2.0 \\
\hline Al & 3.1 & $0.04^{(d)}$ & 0.17 & 1.3 & 5.6 & 2.4 & 0 & 0.14 & 0 & 6.0 & 1.8 & $0.04^{(c)}$ & 0.16 & 2.2 & 8.9 \\
\hline B & 4.5 & 0 & 0.23 & 0 & 5.1 & 3.5 & 0 & 0.41 & 0 & 12.0 & 2.5 & 0 & 0.15 & $\mathbf{0}$ & 6.2 \\
\hline $\mathrm{Ca}$ & $0.16^{(e)}$ & $0.005^{(d)}$ & 0.04 & 3.1 & 22.1 & 0.17 & 0 & 0.01 & 0 & 7.1 & 0.16 & $0.001^{(c)}$ & 0.02 & 0.6 & 10.9 \\
\hline $\mathrm{Fe}$ & 5.1 & $0.03^{(d)}$ & 0.31 & 0.6 & 6.1 & 4.2 & 0 & 0.23 & 0 & 5.6 & 3.2 & $0.02^{(c)}$ & 0.21 & 0.6 & 6.5 \\
\hline $\mathbf{L i}$ & 1.2 & 0 & 0.07 & 0 & 6.2 & 1.0 & 0 & 0.08 & 0 & 8.1 & 0.77 & o & 0.11 & 0 & 14.3 \\
\hline $\mathrm{Na}$ & 4.1 & $0.04^{(d)}$ & 0.32 & 1.0 & 7.8 & 3.4 & 0 & 0.37 & 0 & 10.7 & 2.5 & 0 & 0.52 & 0 & 20.7 \\
\hline si & 18.4 & $0.17^{(d)}$ & 1.19 & 0.9 & 6.5 & 15.3 & 0 & 1.17 & 0 & 7.6 & 11.5 & $0.26^{(c)}$ & 1.26 & 2.3 & 10.9 \\
\hline
\end{tabular}

(a) The mean is calculated excluding the ADS samples.

(b) Standard deviation due to inhomogeneity is the estimated standard deviation between the average weight percents at the six tank sarmple locations.

(c) The analytical standard deviation is calculated from the replicate samples taken within each location.

(d) Not statistically significantly greater than zero.

(e) Calcium data appear to reflect some nonrandom behavior as seen in the residual plots in Appendix B. 
TABLE 6.5. Sampler System Bias and Relative Bias for As-Analyzed Data

\begin{tabular}{|c|c|c|c|c|c|c|c|c|c|}
\hline \multirow[b]{2}{*}{ Element } & \multicolumn{3}{|c|}{ Concentrated } & \multicolumn{3}{|c|}{ Reference } & \multicolumn{3}{|c|}{ Dilute } \\
\hline & Bias & $\begin{array}{r}\text { Rel } \\
\text { Bias (a) } \\
\end{array}$ & Sign. (b) & Bias & $\begin{array}{l}\text { Rel. } \\
\text { Bias } \\
\end{array}$ & Sign. & Bias & $\begin{array}{l}\text { Re } 1 . \\
\text { Bias } \\
\end{array}$ & Sign. \\
\hline Total Solids & 0.16 & $0.3 \%$ & $N$ & 0.59 & $1.6 \%$ & Y & 0.93 & $2.1 \%$ & Y \\
\hline A1 & 0.11 & $3.6 \%$ & Y & 0.12 & $5.1 \%$ & Y & 0.18 & $10.1 \%$ & Y \\
\hline B & 0.16 & $3.7 \%$ & Y & 0.39 & $11.5 \%$ & Y & 0.18 & $7.3 \%$ & Y \\
\hline $\mathrm{Ca}$ & 0.01 & $5.7 \%$ & N & 0.02 & $12.2 \%$ & Y & 0.05 & $29.1 \%$ & Y \\
\hline $\mathrm{Fe}$ & 0.24 & $4.8 \%$ & Y & 0.14 & $3.6 \%$ & Y & 0.31 & $10.1 \%$ & Y \\
\hline Li & 0.03 & $2.7 \%$ & $\mathrm{~N}$ & -0.003 & $0.4 \%$ & $\mathrm{~N}$ & 0.04 & $5.8 \%$ & $\mathrm{~N}$ \\
\hline $\mathrm{Na}$ & 0.09 & $2.3 \%$ & N & -0.04 & $1.0 \%$ & N & 0.24 & $9.8 \%$ & N \\
\hline $\mathrm{Si}$ & 0.57 & $3.1 \%$ & Y & 1.16 & $7.7 \%$ & Y & 1.53 & $13.5 \%$ & Y \\
\hline
\end{tabular}

(a) The relative bias is defined as the bias divided by the average total as-analyzed wt\%.

(b) Sign. refers to statistically significant, (Y)es or (N)o.

bias is greatest when the feed slurry is more dilute. The concentrated slurry, although pumped in the laminar flow regime, has a yield stress that may be preventing the solids from settling.

Although the sampler bias is statistically significant, it is necessary to determine whether the size of the observed bias is practically significant. As discussed in Section 6.2, practical significance is best defined by examining the effect of the bias on the normalized weight percents because the waste acceptance criteria will most likely be in terms of the normalized determinations.

A statistical analysis similar to that presented above was performed on the normalized oxide weight percents. Table 6.6 presents the results of those analyses. The outliers that were detected and deleted from the statistical analyses are shown in Table 6.3. Again, it should be noted that the analytical variation is the dominant source of uncertainty and that the MFHT appears to be homogeneous.

For the concentrated feed, the effect of sampler bias is not statisticaliy significant for the seven constituents. For the dilute feed, the 
IABLE 6.6. Estimates of the Inhomogeneity and Analytical Variations Using the Normalized Data

\begin{tabular}{|c|c|c|c|c|c|c|c|c|c|c|c|c|c|c|c|}
\hline \multirow[b]{2}{*}{ Element } & \multicolumn{5}{|c|}{ Concentrated Slurry } & \multicolumn{5}{|c|}{ Reference } & \multicolumn{5}{|c|}{ Dilute } \\
\hline & $\begin{array}{l}\text { Mean, (a) } \\
\text { wt \% } \\
\end{array}$ & $\begin{array}{l}\text { Inhomo-(b) } \\
\text { gene ity, } \\
\text { Std. Dev. }\end{array}$ & $\begin{array}{l}\text { Ana-(c) } \\
\text { lytical, } \\
\text { Std. Dev. }\end{array}$ & $\begin{array}{l}\text { Inhomo- } \\
\text { geneity, } \\
\text { RSD, \% }\end{array}$ & $\begin{array}{l}\text { Ana- } \\
\text { lyt ical, } \\
\text { RSD, \% }\end{array}$ & $\begin{array}{l}\text { Mean, } \\
w t \% \\
\end{array}$ & $\begin{array}{l}\text { Inhomo- } \\
\text { geneity, } \\
\text { std. Dev. }\end{array}$ & $\begin{array}{c}\begin{array}{c}\text { Ana- } \\
\text { lytical, } \\
\text { std. Dev. }\end{array} \\
\end{array}$ & $\begin{array}{l}\text { Inhomo- } \\
\text { gene ity, } \\
\text { RSD, \% }\end{array}$ & $\begin{array}{c}\text { Ana- } \\
\text { lytical, } \\
\text { RSD,\% }\end{array}$ & $\begin{array}{l}\text { Mean, } \\
\text { wt\% }\end{array}$ & $\begin{array}{l}\text { Inhomo- } \\
\text { genei ty, } \\
\text { Std. Dev. }\end{array}$ & $\begin{array}{c}\begin{array}{c}\text { Ana- } \\
\text { lyt ical, } \\
\text { std. Dev. }\end{array} \\
\end{array}$ & $\begin{array}{r}\text { Inhomo- } \\
\text { geneity, } \\
\text { RSD,\% } \\
\end{array}$ & $\begin{array}{c}\text { Ana- } \\
\text { lyt ical, } \\
\text { RSD, \% }\end{array}$ \\
\hline Al & 7.4 & $0.015^{(d)}$ & 0.29 & 0.2 & 3.9 & 6.9 & 0 & 0.26 & 0 & 3.8 & 7.1 & 0 & 0.30 & 0 & 4.2 \\
\hline B & 10.7 & $0.012^{(d)}$ & 0.36 & 0.1 & 3.4 & 10.0 & 0 & 0.96 & 0 & 9.6 & 9.7 & 0 & 0.60 & 0 & 6.2 \\
\hline $\mathrm{Ca}$ & 0.4 & $0.011^{(d)}$ & 0.07 & 2.8 & 18.7 & 0.5 & 0 & 0.03 & 0 & 6.8 & 0.6 & 0 & 0.05 & 0 & 8.3 \\
\hline $\mathrm{Fe}$ & 12.1 & 0 & 0.33 & 0 & 2.7 & 12.1 & 0 & 0.47 & 0 & 3.9 & 12.3 & 0 & 0.57 & 0 & 4.7 \\
\hline $\mathrm{Li}$ & 2.8 & $0.018^{(d)}$ & 0.15 & 0.1 & 5.3 & 2.9 & 0 & 0.20 & 0 & 6.7 & 3.0 & 0 & 0.32 & 0 & 10.6 \\
\hline $\mathrm{Na}$ & 9.8 & 0.072 & 0.40 & 0.7 & 4.1 & 9.9 & 0 & 0.84 & 0 & 8.4 & 9.7 & $0.073^{(d)}$ & 1.55 & 0.8 & 16.1 \\
\hline si & 44.1 & $0.167^{(d)}$ & 1.16 & 0.4 & 2.6 & 44.4 & 0 & 1.40 & 0 & 3.2 & 44.5 & $0.208^{(d)}$ & 2.07 & 0.5 & 4.7 \\
\hline
\end{tabular}

(a) The mean is calculated excluding the ADS samples.

(b) Standard deviation due to inhomogeneity is the estimated standard deviation between the average weight percents at the six tank sample locations.

(c) The analytical standard deviation is calculated from the replicate samples taken within each location.

(d) Not statistically significantly greater than zero. 
sampler bias is significant for only $\mathrm{Ca}$. However, for the reference feed, there is a sampler bias for $\mathrm{Ca}, \mathrm{Li}$, and $\mathrm{Na}$, and possibly for $\mathrm{B}$ and $\mathrm{Si}$. The bias is positive for $\mathrm{Ca}, \mathrm{B}$, and $\mathrm{Si}$ but negative for $\mathrm{Li}$ and $\mathrm{Na}$.

An explanation for the normalized sampler bias results can be found by examining the as-analyzed relative biases shown in Table 6.5. When the sampler relative bias is somewhat consistent across all constituents, as is the case for the concentrated slurry, the effect of normalizing cancels any bias. However, when the relative bias is not consistent across all constituents, as is the case for the reference and dilute slurries, normalizing underestimates the elemental concentration for those constituents with little or no sampler bias in the as-analyzed results. However, normalizing does not entirely eliminate the bias for those elements that had a large relative bias on the as-analyzed data.

The above discussion illustrates the problem of determining the effects of various conditions by examining the normalized values. Although normalizing may be appropriate in certain applications, it can be deceptive when certain conditions affect some elements but not others or affect all elemental constituents similarly. The effect of those changing conditions may be hidden by the normalizing technique. Thus, careful use of normalized values is recommended.

The size of the sampler biases for the normalized data is shown in Table 6.7. Because the magnitude of the absolute biases for the reference material is large with respect to the estimated standard deviations due to random analytical variations, a decrease in the bias would have a practical, significant influence on the accuracy and precision of sample determinations obtained from the MFHT. Thus, it would prove beneficial to improve the ability of the sampler system to obtain more representative samples from the MFHT. Additionally, because there were no significant differences between the average elemental concentrations or total solids at each of the six tank sampling locations, the slurry within the MFHT appears to be homogeneous under the conditions of this experiment.

It is likely that the sample bottle used in these experiments (see Figure 5.4b) allowed solids to settle in the bottom of the bottle, which could 
TABLE 6.7. Sampler System Bias and Relative Bias for Normalized Data

\begin{tabular}{|c|c|c|c|c|c|c|c|c|c|}
\hline \multirow[b]{2}{*}{ Element } & \multicolumn{3}{|c|}{ Concentrated } & \multicolumn{3}{|c|}{ Reference } & \multicolumn{3}{|c|}{ Dilute } \\
\hline & Bias & $\begin{array}{l}\text { Rel. } \\
\text { Bias (a) }\end{array}$ & Sign. (b) & Bias & $\begin{array}{l}\text { Rel. } \\
\text { Bias } \\
\end{array}$ & Sign. & Bias & $\begin{array}{l}\text { Rel. } \\
\text { Bias } \\
\end{array}$ & Sign. \\
\hline Al & 0.01 & $0.1 \%$ & $\mathrm{~N}$ & -0.06 & $0.8 \%$ & $N$ & -0.01 & $0.2 \%$ & $\mathrm{~N}$ \\
\hline B & 0.06 & $0.6 \%$ & $N$ & 0.57 & $5.8 \%$ & Mar & -0.27 & $2.7 \%$ & $\mathrm{~N}$ \\
\hline $\mathrm{Ca}$ & 0.01 & $1.7 \%$ & $\mathrm{~N}$ & 0.03 & $6.9 \%$ & Y & 0.09 & $13.9 \%$ & Y \\
\hline $\mathrm{Fe}$ & 0.18 & $1.5 \%$ & $\mathrm{~N}$ & -0.26 & $2.1 \%$ & $N$ & 0.05 & $0.4 \%$ & $N$ \\
\hline Li & -0.02 & $0.5 \%$ & $N$ & -0.14 & $5.8 \%$ & $Y$ & -0.17 & $4.6 \%$ & $N$ \\
\hline $\mathrm{Na}$ & 0.07 & $0.8 \%$ & $N$ & -0.57 & $5.7 \%$ & Y & -0.13 & $1.4 \%$ & $N$ \\
\hline Si & 0.05 & $0.1 \%$ & $\mathbf{N}$ & 0.79 & $1.8 \%$ & Mar & 0.85 & $1.9 \%$ & $\mathrm{~N}$ \\
\hline
\end{tabular}

(a) The relative bias is defined as the bias divided by the average total normalized weight percents.

(b) Sign. refers to statistically significant: (Y)es, (N)o or (Mar)ginal.

account for the higher weight percent solid determinations obtained from these samples. In addition, rheological evaluations of the slurries (Section 6.1) indicated that the reference and dilute concentrations were pumped in the transitional flow regime and the concentrated slurry was pumped in the laminar flow regime. Solids may be momentarily settling in the line during low flow, then resuspending when the next pulse of flow is delivered by the ADS pump.

In summary, results from the homogeneity/sampling system tests indicated that the agitator in the MFHT provides a homogeneous mixture of the three concentrations of slurry tested. In addition, the ADS pump/Hydragard sampling system appears to obtain a sample that is higher in solids.

\subsection{RESUSPENSION TESTS}

The resuspension tests were designed to determine the length of time required by the agitation system to obtain a homogeneous slurry after a simulated, unscheduled power outage. The samples taken for these tests were analyzed only for weight percent total solids. The tank was considered homogenous if there were no significant differences (less than $2.1 \mathrm{wt} \%$ ) between 
the determinations of average weight percent total solids from the samples analyzed. The samples were taken at six sampling locations within the MFHT (see Figure 4.1).

A three-factor analysis of variance was conducted to determine the significance of the wait-time, tank depth, and access nozzle effects, and test whether the individual effects of each of the three factors were consistent when compared to other factors (two-factor and three-factor interactions). For example, there may be no difference between the total solids at the top, bottom, and middle of the tank after $6 \mathrm{hrs}$ of mixing, but there may be a difference between total solids at those tank levels after 2 hrs of mixing. This example represents a two-factor interaction between tank depth and waittime.

Although the data contained a few outliers, the conclusions derived from the statistical analyses were not affected by including or excluding the outliers. Therefore, all data were included in the statistical analyses. The results of the analyses are shown in Table 6.8 .

TABLE 6.8. Results of Statistical Analys is of Resuspension Data

\begin{tabular}{|c|c|c|c|}
\hline Effect & Concentrated & Reference & Dilute \\
\hline Wait-Time & $N^{(a)}$ & $Y$ & Y \\
\hline Tank Depth & $\mathrm{N}$ & $Y$ & N \\
\hline Nozzle & $\mathrm{N}$ & Mar. & $\mathrm{N}$ \\
\hline Interactions & $\mathrm{N}$ & $\mathrm{N}$ & $\mathrm{N}$ \\
\hline Std. Dev. $(\sigma)$ & 1.20 & 0.87 & 0.49 \\
\hline Overall Average & $49.9 w t \%$ & 44.0 wt\% & $36.0 \mathrm{wt} \%$ \\
\hline RSD & 2.4 & 2.0 & 1.4 \\
\hline $\begin{array}{l}\text { "N" signif } \\
\text { less than } \\
\text { percent so } \\
\text { nificant } \mathrm{e} \\
\text { significant }\end{array}$ & $\begin{array}{l}\text { no significan } \\
\text { wt\% between } t \\
\text { measurements } \\
t \text {, and "Mar." } \\
\text { fect (differer }\end{array}$ & $\begin{array}{l}\text { fect (diffe } \\
\text { verage weig } \\
\text { Y" signifie } \\
\text { a marginal } \\
\text { less than }\end{array}$ & ces \\
\hline
\end{tabular}


A preliminary analysis showed that the results obtained from the resuspension test using the concentrated melter feed were more variable than the results obtained using the reference and concentrated melter feed. The results from the test using the dilute melter feed were the least variable. Thus, a separate statistical analysis was conducted for each slurry concentration.

\subsubsection{Concentrated Melter Feed STurry}

For the concentrated slurry, there were no significant effects or interactions as a result of wait-time, tank depth, or access nozzle. Thus, for a similar concentrated slurry, homogeneity is reached after only $2 \mathrm{hrs}$ of mixing.

It should be noted that the average weight percent total solids is 49.9 for the samples taken during the resuspension tests, and 51.1 for those taken during the homogeneity tests. The apparent difference resulted from the analytical variations over time. To aid in the quality control efforts for these experiments, a control sample was obtained from the tank during the homogeneity/sampling system test using the concentrated melter feed slurry. This sample was divided into numerous analytical samples that were submitted to the analytical laboratory to be analyzed with the other samples.

The control samples were analyzed every sixteenth sample. The sample was submitted throughout the concentrated, dilute, and reference sample analyses. Figure 6.4 plots the total solids determination by analytical order for the control sample. During the analysis of the concentrated resuspension samples, three of the control sample analyses were less than $49 \mathrm{wt} \%$, whereas the results obtained during the homogeneity tests were mostiy clustered around $51 \mathrm{wt} \%$. Thus, it appears that long-term analytical variations account for the difference between the weight percent solids analyzed for the homogeneity/sampling system and resuspension tests. The magnitude of the long-term analytical variations will affect the number of analyses required during actual operations. Methods to reduce this effect are discussed in Section 6.5. 


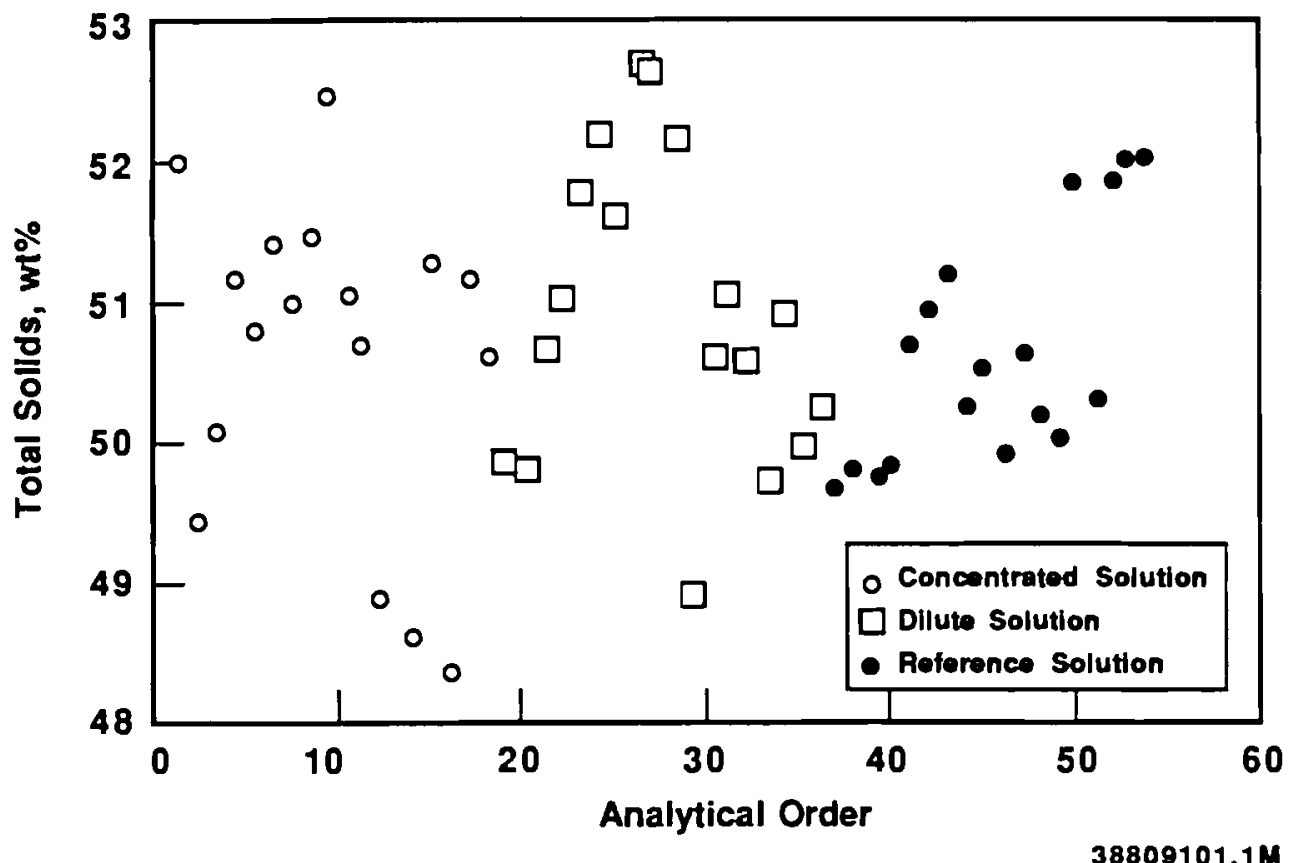

FIGURE 6.4. Total Solids Versus Analytical Order for the Control Samples

\subsubsection{Reference Melter Feed Slurry}

The results of the statistical analys is on the reference slurry resuspension tests are somewhat ambiguous. A significant wait-time effect caused the average total solids concentration to decrease with mixing time, contrary to expected results. The averages are shown in Table 6.9. At this time there is no reasonable explanation for the decrease in total solids as the tank continues mixing. It should be noted that all the 2 -hr samples were obtained first, followed by the 6-hr samples then the 24-hr samples. Because of this restriction on randomization, the effect of wait-time is completely confounded with sampling order.

There also is a significant tank depth effect on the reference resuspension tests. The average total solids at the bottom and middle of the tank appear to be less than the total solids at the top of the tank. Again, this result is unexpected. Finally, a marginally significant difference exists between the nozzle $C$ and $D$ total solids. No significant interactions were manifested between the three factors of interest. 
TABLE 6.9. Averages Representing the Significant Effects Shown in Table 6.8

Reference Slurry:

\begin{tabular}{cccc} 
Wait-Time Effect & & Average Total Solids & Sign. (a) \\
\hline 2 hours & $44.53 w t \%$ & A \\
6 hours & $44.03 w t \%$ & B \\
24 hours & $43.44 w t \%$ & $C$
\end{tabular}

Tank Depth Effect

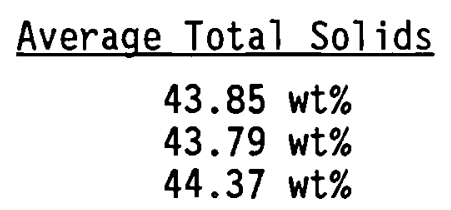

Sign.

Bottom

Middle

Top

$44.37 \mathrm{wt} \%$

A

A

$\frac{\text { Nozzle Effect }}{\text { C }}$

Average Total Solids

$44.16 w t \%$

$43.84 w t \%$

B

Dilute STurry:

Wait-time Effect
2 hours
6 hours
24 hours
Average Total Solids
$35.93 w t \%$
$35.79 w t \%$
$36.33 w t \%$

Sign.

A

B

$A$
$B$ 
As discussed in Section 6.2, the 2- and 6-hr samples were analyzed before the $24-\mathrm{hr}$ samples. Figure 6.4 shows that the control samples analyzed near the end of the dilute analyses appear to have much higher total solids than those analyzed with the first part of the resuspension dilute samples. Those high control samples correspond with the 24-hr samples such that the difference between the $24-\mathrm{hr}$ and the 2 - and 6-hr results are completely confounded with a change in the analytical laboratory. Thus, it appears that the dilute slurry in the MFHT is probably homogeneous after $2 \mathrm{hr}$ of mixing.

In summary, the concentrated and dilute slurry resuspension tests show that homogeneity is reached in the MFHT after only $2 \mathrm{hr}$ of agitation. The results of the reference slurry resuspension tests are not as expected, although they are statistically significant. Assuming that some other unknown factor contributed to the reference slurry resuspension results, an agitation of $2 \mathrm{hr}$ after agitator shutdown is recommended to obtain a homogeneous slurry.

\subsection{ANALYTICAL UNCERTAINTIES}

As the statistical analyses progressed, it became apparent that the analytical variations were not entirely random. In the test plan, the analytical order was completely randomized within each slurry concentration for the homogeneity tests and the resuspension tests (with the exception of the 24-hr resuspension samples, which were always analyzed last within a slurry concentration). Plots of the total solids or elemental weight percents after removing the effects of the factors studied in the experiment (residual plots) should resemble a random band of values when plotted by analytical order. However, as seen in the residual plots shown in Appendix $B$ (Figures B.1 through B.24), there are definite trends across analytical order. These long-term effects account for a sizable portion of the total analytical variation.

In addition to the long-term trends, several plots show clusters of data that are out of 1 ine with the rest of the data (e.g., Figures B.6, B.12, and 
B.13). Because these outlying values occur in a cluster over time, it is apparent that the contributing factor can be attributed to the analytical laboratory.

Plots of the analytical determinations for the control samples are shown in Appendix B (Figures B.25 through B.31). These plots also reveal the longterm analytical variation. The magnitude of the analytical uncertainty will directly affect the number of analyses that will be required during actual "hot" operations. If the analytical uncertainties can be reduced, the required number of feed analyses for characterization and waste form qualification purposes can be reduced. Moreover, if the analytical uncertainty is reduced, the cold chemical addition recipe will be more accurate, thereby improving the ability to produce a glass composition that is nearer the optimal target composition.

Reducing analytical uncertainty should begin with statistical quality control charting using control standards that are representative of the feed slurry. The standards should represent the full spectrum of the elemental matrixes found in the feed slurry, and should include all of the analytical preparation steps. The analytical process must first be brought into statistical control by identifying and eliminating the special causes of variation (i.e., those variations that present themselves in unpredictable ways). A special-cause variation produces erratic outliers, a cluster of outliers, or a sudden shift in the analytical results. When a method has been implemented to assure statistical control, a program could be undertaken to reduce the "common cause" variations by eliminating or reducing long-term variations. Such a program would involve careful study of the control charts, statistical evaluation of any correlative behavior of data available on other variables, and statistical design and analysis of experiments examining the hypotheses proposed to identify the sources of long-term uncertainty.

Because long-term analytical uncertainty is a major portion of the total analytical uncertainty, and a reduction in the analytical uncertainty is highly desirable because of the reduced cost and improved quality of the 
product, it is recommended that a statistical quality control program as described above be implemented in the analytical laboratory.

\subsection{SCALE-UP VERIFICATION}

Bench-scale mixing tests were performed in 1986 to provide a rational basis for the design of full-scale mixing systems (Peterson, McCarthy and Muhlstein 1986). One of the mixing systems evaluated was the MFHT. However, the MFHT was not designed at the time the bench-scale tests were conducted, and assumptions were made about the system design. The full-scale system is not geometrically, kinematically, or dynamically similar to the bench-scale system. Therefore, an exact verification of the scale-up procedure was not possible. Although the scale-up procedure used in Peterson, McCarthy and Muhlstein (1986) could not be verified, it is concluded that the design of the MFHT mixing system is suitable for homogenizing the tank contents.

\subsubsection{Geometric Similarities}

The dimensions of the bench-scale and the MFHT mixing systems are shown in Table 6.10. As shown in this table, the two systems are not geometrically similar. The greatest difference between the two mixing systems can be attributed to the different impellers. This difference is highlighted by the pumping numbers, which are much lower for the high-efficiency turbines used in the MFHT. The tank geometric ratios are also different in some cases, although this difference is not as significant as the differences in the impellers.

\subsubsection{Kinematic and Dynamic Similarities}

The Reynolds number and power number were determined for the MFHT and are compared to the parameters estimated from a scale-up procedure (Peterson, McCarthy and Muhlstein 1986) (Table 6.11 and Figure 6.5). The relatively large Reynolds numbers for the MFHT mixing system indicate that the system was operating in the turbulent flow region (i.e., Re $>100,000$ ). The large variation in the Reynolds numbers is primarily a result of the variation in the apparent viscosity of the slurries. The power number for the MFHT mixing system is much lower than that for the bench-scale mixing system because different types of impellers were used. The large variation in viscosity has 
IABLE 6.10. Comparison of Geometric Mixing System Parameters

\section{Parameters}

Top Impeller

Number of blades

Type of blade

Pumping number, $\mathrm{N}_{\mathrm{Q}}$

Bottom Impeller

Number of blades

Type of blade

Pumping number, $\mathrm{N}_{\mathrm{Q}}$

Dimensions

Tank dia. ( $T$ ), in.

Impeller dia. (D), in.

Liquid level (L), in.

Clearance between impeller and tank bottom $\left(C_{1}\right)$, in.

Distance between impellers $\left(C_{2}\right)$, in.

Baffle width $\left(B_{w}\right)$, in.

Impeller rotational speed (N), rpm

Geometric Ratios

$T / D$

$\mathrm{L} / \mathrm{D}$

$L / T$

$C_{1} / D$

$\mathrm{C}_{2} / \mathrm{D}$

$\mathrm{Bw} / \mathrm{D}$
Bench-Scale Mixing

System

3

High-efficiency turbine

0.78

4

Flat-blade turbine

0.8

15

4.5

15

0.9

4.5

1.2

$30-1000$

3.3

3.3

1

0.2

1

0.27
Full-Scale Mixing

System

3

High-efficiency turbine

0.47

3

High-efficiency turbine

0.47
120

36

102

11.6

56

10

155

very little impact on the power number because the inertial forces are much larger than the viscous forces in the turbulent flow region. The power delivered to the fluid is primarily a function of the density of the fluid and is nearly independent of the viscosity. Even though there were significant differences between the bench-scale and the MFHT mixing systems, 
IABLE 6.11. Comparison of Kinematic and Dynamic Mixing System Parameters

\begin{tabular}{|c|c|c|c|c|}
\hline Slurry Concentration & $\begin{array}{l}\text { Apparent } \\
\text { Viscosity } \\
\text { (cP) } \\
\end{array}$ & $\begin{array}{c}\text { Reynolds, } \\
\text { Number, } \\
\text { Re } \\
\end{array}$ & $\begin{array}{c}\text { Power } \\
\text { Number, } \\
\mathrm{Np} \\
\end{array}$ & $\begin{array}{l}\text { Estimated } \\
\text { Power to } \\
\text { Fluid (Hp) }\end{array}$ \\
\hline Concentrated & 22.1 & 140,000 & 0.64 & 13.7 \\
\hline Reference & 3.1 & 900,000 & 0.69 & 13.5 \\
\hline Dilute & 2.7 & $1,000,000$ & 0.70 & 13.3 \\
\hline Full-scale estimate & 19 & 74,800 & 5.0 & 14.8 \\
\hline
\end{tabular}

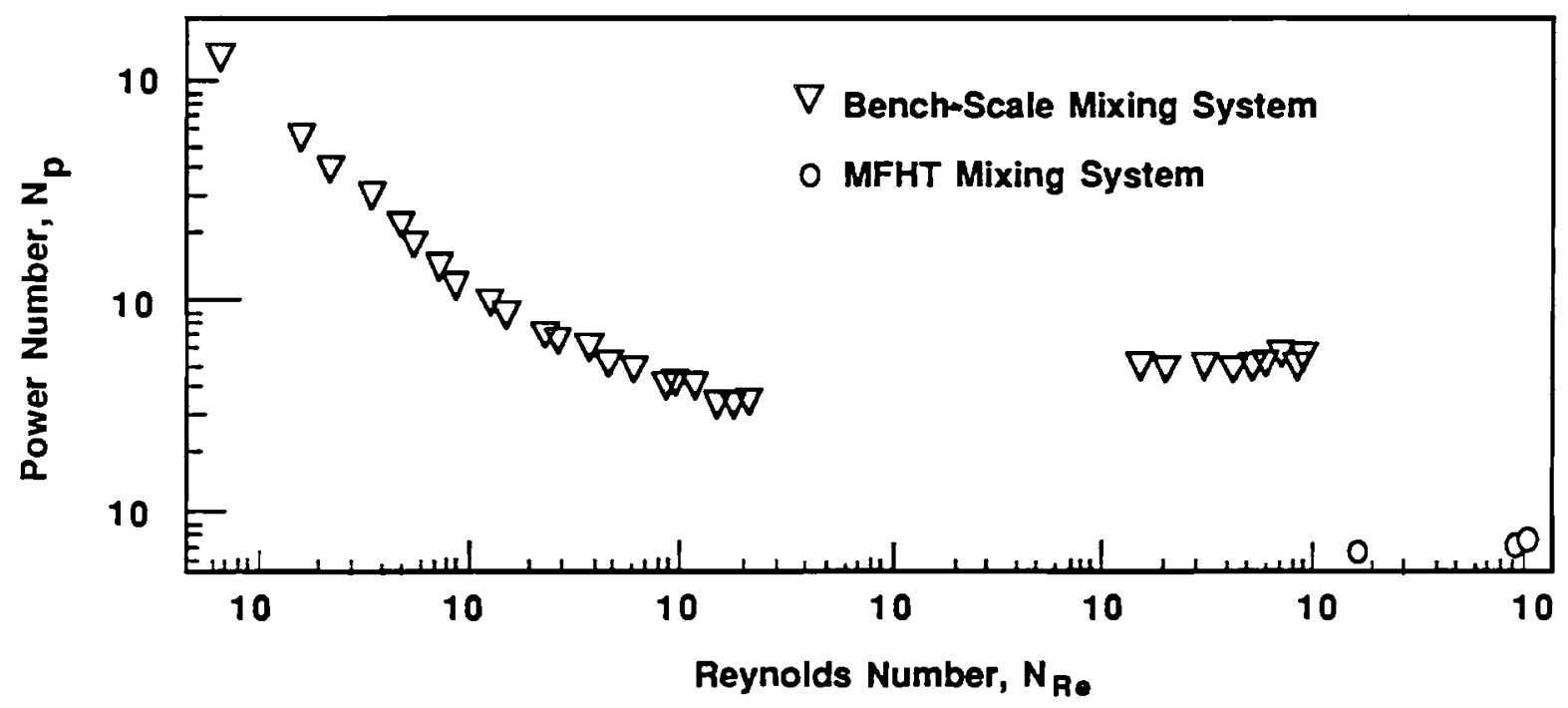

$38807138.4 M$

FIGURE 6.5. Power Number Versus Reynolds Number for the Bench-Scale and Full-Scale Mixing Systems

the actual estimated power delivered to the fluid was only slightly smaller than the full-scale estimate based on bench-scale testing.

The data in Table 6.11 for the MFHT mixing test was calculated using the equations presented in Section 3 and rheological data presented in Sec-

tion 6.1.2. The apparent viscosities for the slurries tested in the MFHT were estimated from Equation 3.4 using the rheological data from Figures 6.1, 6.2 , and 6.3. The Reynolds numbers were calculated using Equation 3.8 and 
the apparent viscosities. The power number was calculated using Equation 3.7, the fluid properties, the mixing system parameters in Table 6.10, and an estimate of the power delivered to the fluid.

The scale of agitation was calculated for the MFHT using the volumetric flow rate $(29,700 \mathrm{gpm})$ supplied by the agitator manufacturer. Results from these calculations are presented in Table 6.12. Using the manufacturersupplied flow rate and the cross sectional area of the MFHT, the bulk velocity was estimated using Equation 3.13. The scale of agitation was calculated using Equation 3.14. The calculated scale of agitation for the MFHT compares well with the scale of agitation recommended by Peterson, McCarthy and Muhlstein (1986).

The scale of agitation should be the same for the three slurries tested since the mixing system was operated in the turbulent flow region. This is shown by Equation 6.1, which is obtained by combining Equations 3.12, 3.13, and 3.14 .

$$
N_{I}=\frac{N_{Q} N D^{3}}{3.05 A}
$$

In the MFHT mixing system, the rotational speed (N), the impeller diameter $(D)$, and the tank area (A) are fixed. Since the pumping number $\left(N_{Q}\right)$ is a constant in the turbulent flow region where the MFHT mixing system operates, the scale of agitation is also constant.

\section{TABLE 6.12. Scale of Agitation}

$\begin{array}{lc}\text { Pumping capacity (supplied by manufacturer) } & 29,700 \mathrm{gpm} \\ \text { Calculated bulk velocity } & 50.6 \mathrm{ft} / \mathrm{min} \\ \text { Calculated scale of agitation (all slurries tested) } & 8.4 \\ \text { Recommended scale of agitation } & 8.0 \\ \quad \text { (Peterson et al. 1986) } & \\ \text { Pumping number (both turbines), } \mathrm{N}_{Q} & 0.94\end{array}$




\subsubsection{Conclusions}

The scale-up from the bench-scale mixing system was qualitatively verified because the testing and statistical analysis showed that the tank was homogeneous for the three slurries tested. As shown in Section 6.3, Table 6.4, there were no significant differences between the six different sampling locations. This result is expected since the MFHT was tested at very high Reynolds numbers, indicating a high level of turbulence and mixing. The actual power requirement for a scale of agitation of 8 in the MFHT was within $10 \%$ of the power requirement estimated from the bench-scale mixing experiments.

Since the system operates at such a high Reynolds number, there is significant flexibility for handling feeds with a wide range of properties. As shown in the Table 6.11 , the apparent viscosity can change by nearly an order of magnitude and mixing will remain in the turbulent flow region. If the mixing system is operated in the turbulent flow region, the scale of agitation should not change significantly and the feed mixture should be homogenous. 


\subsection{REFERENCES}

Ande, T. C., N. T. Cowper, T. L. Thompson, and E. J. Wasp. 1971. "Slurry Piping Systems: Trends," Chem. Eng. June 28, 1971.

Bates, R. L. et al. 1966. "Impeller Characteristics and Power." In Mixing I, Edited by Uhl and Gray, Academic Press, New York.

Bird, R.D. et a1. 1960. Transport Phenomenon. John Wiley, New York, New York.

Box, G. E. P., W. G. Hunter, and J. S. Hunter. 1978. Statistics For Experimenters, John Wiley and Sons, New York, New York.

Dickey, D. S. and J. C. Fenic. 1976. "Dimensional Analysis for Fluid Agitation Systems." Chem. Eng. 83:144.

Gates, L. E., J. R. Morton, and P. L. Fondy. 1976. "Selecting Agitator Systems to Suspend Solids in Liquids." Chem. Eng. 83:144.

Hanks, R. W. 1978. "Low Reynolds Number Turbulent Flow of Pseudohomogenous Slurries." Paper presented at the Fifth International Conference on Hydraulic Transport of Solids in Pipes, Hanover, Germany, BHRA Fluid Engineering, Bedford, England.

Hicks, R. W., J. R. Morton, and J. G. Fenic. 1976. "How to Design Agitators for the Desired Process Response." Chem. Eng. 83:102.

Metzner, A. B., and R. E. Otto. 1957. "Agitation of Non-Newtonian Fluids." AIChEJ $3: 1(3)$.

Peterson, M. E., D. McCarthy, and K. D. Muhlstein. 1986. Design of Mixing System for Simulated High-Level Nuclear Waste Melter Feed Slurries. PNL5745, Pacific Northwest Laboratory, Richland, Washington.

Rautzen, R. R., R. R. Corpstein, and D. S. Dickey. 1976. "How to Use ScaleUp Methods for Turbine Agitators." Chem. Eng. 23:119. 
1 


\section{APPENDIX A}

\section{SAMPLE AND ANALYSIS ORDER}




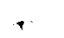


APPENDIX A

\section{SAMPLE AND ANALYSIS ORDER}

Two types of tests were performed at West Valley using three concentrations of simulated, nonradioactive melter feed slurry. These two tests are called the homogeneity/sampling system test and the resuspension test. The homogeneity/sampling system test was performed to characterize the melter feed system at West Valley and to verify the scale-up of the bench-scale mixing studies performed at PNL. The resuspension test was performed to determine the time required to resuspend the solids and homogenize the melter slurry in the melter feed hold tank (MFHT) after an unexpected power outage.

The tests were statistically designed by PNL to determine whether an adequately homogeneous solution is obtained in the MFHT, and whether the liquid-sampling system provides a representative sample of the melter feed. The statistical design for the homogeneity and sampling system test determined that 21 samples at each of the seven sampling locations [six in the tank (Figure 4.1), plus the liquid-sampling system] were required to provide a $95 \%$ confidence that the correct conclusions were drawn. Only six samples at the six tank sampling locations were required for the resuspension tests.

The samples were taken from the tank and analyzed in a predetermined, random order. The sampling order for the homogeneity and sampling system tests is summarized in Tables A.1 through A.3. For the resuspension tests, the sampling order is summarized in Tables A.4 through A.6. The analysis order for the homogeneity and sampling system tests and the resuspension tests are summarized in Tables A.7 through A.9 and Tables A.10 through A.12, respectively. 
TABLE A.1. Sampling Order for the Homogeneity and Sampling System Test Using the Concentrated Melter Feed Slurry

\begin{tabular}{|c|c|c|c|c|c|c|c|c|c|c|c|}
\hline \multirow{2}{*}{$\frac{\text { Order }}{1}$} & \multicolumn{2}{|c|}{ Location $^{(a)}$} & \multirow{2}{*}{$\frac{\text { Order }}{43}$} & \multicolumn{2}{|c|}{ Location } & \multirow{2}{*}{$\frac{\text { Order }}{85}$} & \multicolumn{2}{|c|}{ Location } & Order & \multicolumn{2}{|c|}{ Location } \\
\hline & TOP & NOZZLE C & & MIDDLE & NOZZLE $D$ & & SAMPLER & & 127 & MIDDLE & NOZZLE C \\
\hline 2 & BOTTOM & NOZZLE D & 44 & SAMPLER & & 86 & вотTON & NOZZLE C & 128 & TOP & NOZZLE D \\
\hline 3 & MIDDLE & NOZZLE C & 45 & MIDDLE & NOZZLE D & 87 & TOP & NOZZLE D & 129 & SAMPLER & \\
\hline 4 & MIDDLE & NOZZLE C & 46 & MIDDLE & NOZZLE C & 88 & ВОTTOM & NOZZLE C & 130 & TOP & NOZZLE C \\
\hline 5 & MIDDLE & NOZZLE D & 47 & TOP & NOZZLE D & 89 & SAMPLER & & 131 & TOP & NOZZLE D \\
\hline 6 & TOP & NOZZLE C & 48 & SAMPLER & & 90 & BOTTON & NOZZLE D & 132 & TOP & NOZZLE C \\
\hline 7 & TOP & NOZZLE D & 49 & ВОT TOM & NOZZLE D & 91 & MIDDLE & NOZZLE D & 133 & BOTTOM & NOZZLE D \\
\hline 8 & TOP & NQZZLE C & 50 & SAMPLER & & 92 & MIDDLE & NOZZLE D & 134 & SAMPLER & \\
\hline 9 & SAMPLER & & 51 & MIDDLE & NOZZLE C & 93 & TOP & NOZZLE C & 135 & BOTTAN & NOZZLE C \\
\hline 10 & MIDDLE & NOZZLE D & 52 & $T O P$ & NOZZLE $O$ & 94 & SAMPLER & & 136 & TOP & NOZZLE D \\
\hline 11 & MIDDLE & NOZZLE C & 53 & MIDDLE & NOZZLE D & 95 & MIDDLE & NOZZLE D & 137 & TOP & NOZZLE D \\
\hline 12 & SAMPLER & & 54 & MIDDLE & NOZZLE C & 96 & TOP & NOZZLE C & 138 & MIDDLE & NOZZLE C \\
\hline 13 & TOP & NOZZLE D & 55 & SAMPLER & & 97 & вотТОМ & NOZZLE C & 13 & TOP & NOZZLE D \\
\hline 14 & SAMPLER & & 56 & TOP & NOZZLE D & 98 & SAMPLER & & 140 & BOTTON & NOZZLE D \\
\hline 15 & ВотTON & NOZZLE C & 57 & ВОт TOM & NOZZLE & 99 & TOP & NOZZLE D & 14 & MIDDLE & NOZZLE D \\
\hline 16 & BOTTON & NOZZLE D & 58 & MIDDLE & NOZZLE C & 100 & TOP & NOZZLE C & 142 & Воттом & NOZZLE D \\
\hline 17 & BOTTON & NOZZLE D & 59 & ВотTON & NOZZLE C & 101 & TOP & NOZZLE C & 143 & BOTTON & NOZZLE D \\
\hline 18 & TOP & NOZZLE D & 60 & SAMPLER & & 102 & SAMPLER & & 144 & ВоTTOM & NOZZLE C \\
\hline 19 & BOTTON & NOZZLE C & 61 & BOTTOM & NOZZLE D & 103 & MIDDLE & NOZZLE D & 145 & MIDDLE & NOZZLE D \\
\hline 20 & BOTTOM & NOZZLE C & 62 & MIDDLE & NOZZLE D & 104 & TOP & NOZZLE C & 146 & MIDDLE & NOZZLE C \\
\hline 21 & ВотTON & NOZZLE D & 63 & MIDDLE & NOZZLE C & 105 & ВотTOM & NOZZLE C & 14 & ВОтTOM & ZLE D \\
\hline 22 & MIDDLE & NOZZLE D & 64 & TOP & NOZZLE D & 106 & TOP & NOZZLE C & 148 & MIDDLE & NOZZLE D \\
\hline 23 & ВОTTON & NOZZLE D & 65 & MIDDLE & NOZZLE C & 107 & TOP & NOZZLE D & 149 & BOTTOM & NOZZLE D \\
\hline 24 & MIDDLE & NOZZLE C & 66 & MIDDLE & NOZZLE C & 108 & MIDDLE & NOZZLE C & 150 & SAMPLER & \\
\hline 25 & TOP & NOZZLE D & 67 & TOP & NOZZLE D & 109 & TOP & NOZZLE C & 151 & ВОTTOM & NOZZLE C \\
\hline 26 & SAMPLER & & 68 & MIDDLE & NOZZLE D & 110 & ВотTOM & NOZZLE C & 152 & TOP & NOZZLE C \\
\hline 27 & MIDDLE & NOZZLE C & 69 & ВОт TOM & NOZZLE D & 111 & TOP & NOZZLE C & 153 & MIDDLE & NOZZLE D \\
\hline 28 & TOP & NOZZLE D & 70 & MIDDLE & NOZZLE D & 112 & SAMPLER & & 154 & BOTTAM & NOZZLE C \\
\hline 29 & BOTTOM & NOZZLE D & 71 & MIDDLE & NOZZLE D & 113 & BOTTOM & NOZZLE D & & & \\
\hline 30 & BOTTON & NOZZLE C & 72 & & NOZZLE & 114 & MIDDLE & NOZZLE D & & & \\
\hline 31 & & NOZZLE D & 73 & DLE & NOZZLE & 115 & SAMPLER & & & & \\
\hline 32 & ВОTTOM & NOZZLE D & 74 & MIDDLE & NOZZLE O & 116 & BOTTOM & NOZZLE C & & & \\
\hline 33 & TOP & NOZZLE D & 75 & ВОTTOM & NOZZLE & 117 & MIDDLE & NOZZLE D & & & \\
\hline 34 & ВОTTOM & NOZZLE D & 76 & ВОтTOM & NOZZLE D & 118 & MIDDLE & NOZZLE C & & & \\
\hline 35 & ВОTTOA & NOZZLE C & 77 & ВОтTOM & NOZZLE C & 119 & воттом & NOZZLE D & & & \\
\hline 36 & SAMPLER & & 78 & MIDDLE & NOZZLE & 120 & TOP & NOZZLE C & & & \\
\hline 37 & TOP & NOZZLE D & 79 & TOP & NOZZLE D & 121 & BOTTOM & NOZZLE D & & & \\
\hline 38 & TOP & NOZZLE C & 80 & SAMPLER & & 122 & MIDDLE & NOZZLE C & & & \\
\hline 39 & MIDDLE & NOZZLE D & & TOP & NOZZLE & 123 & воттом & NOZZLE C & & & \\
\hline (n & SAMPLER & & & MIDDLE & NOZZLE D & 124 & TOP & NOZZLE & & & \\
\hline 41 & TOP & NOZZLE C & 83 & MIDDLE & NOZZLE D & 125 & воттOM & NOZZLE & & & \\
\hline 42 & TOP & NOZZLE C & 84 & TOP & NOZZLE D & 126 & вотTOM & NOZZLE C & & & \\
\hline
\end{tabular}

(a) See Figure 4.1.

(b) "Sampler" refers to Liquid Sampl ing System.

(c) A $250 \mathrm{ml}$ sample was drawn. This sample is referred to as the "CONTROL" sample. 
TABLE A.2. Sampling Order for the Homogeneity and Sampling System Test Using the Reference Melter Feed Slurry

\begin{tabular}{|c|c|c|c|}
\hline Order & Locat i & ion (a) & \\
\hline 1 & TOP & NOZZLE & \\
\hline 2 & TOP & NOZZLE & \\
\hline 3 & MIDDLE & NOZZLE & D \\
\hline 4 & SAMPLER & & \\
\hline 5 & MIDDLE & NOZZLE & \\
\hline 6 & BOTTOM & NOZZLE & \\
\hline 7 & TOP & NOZZLE & \\
\hline 8 & TOP & NQZZLEE & D \\
\hline 9 & SAMPLER & & \\
\hline 10 & ВотTOM & NOZZLE & C \\
\hline 11 & TOP & NOZZLE & \\
\hline 12 & TOP & NOZZLE & \\
\hline 13 & TOP & NOZZLE & D \\
\hline 14 & MIDDLE & NOZZLE & D \\
\hline 15 & MIDDLE & NOZZLE & D \\
\hline 16 & ВотTOM & NOZZLE & C \\
\hline 17 & TOP & NOZZLE & D \\
\hline 18 & TOP & NOZZLE & C \\
\hline 19 & вотTOM & NOZZLE & D \\
\hline 20 & SAMPLER & & \\
\hline 21 & ВОTTOM & NOZZLE & C \\
\hline 22 & ВОTTOM & NOZZLE & D \\
\hline 23 & ВОTTOM & NOZZLE & \\
\hline 24 & ВОTTOM & NOZZLE & c \\
\hline 25 & MIDDLE & NOZZLE & D \\
\hline 26 & SAMPLER & & \\
\hline 27 & MIDDLE & NOZZLE & \\
\hline 28 & MIDDLE & NOZZLE & \\
\hline 29 & MIDDLE & NOZZLE & C \\
\hline 30 & TOP & NOZZLE & D \\
\hline 31 & MIDDLE & NOZZLE & D \\
\hline 32 & SAMPLER & & \\
\hline 33 & TOP & NOZZLE & C \\
\hline 34 & BOTTOM & NOZZLE & \\
\hline 35 & MIDDLE & NOZZLE & \\
\hline 36 & MIDDLE & NOZZLE & \\
\hline 37 & MIDDLE & NOZZLE & C \\
\hline 38 & BOTTOM & NOZZLE & \\
\hline 39 & MIDDLE & NOZZLE & \\
\hline 40 & TOP & NOZZLE & c \\
\hline 41 & SAMPLER & & \\
\hline 42 & вотTOM & NOZZLE & \\
\hline
\end{tabular}

Order Location Order BOTTOM TOP BOTTOM NOZZLE D MIDDLE NOZZLE C TOP NOZZLE C TOP NOZZLE C SAMPLER

MIDDLE NOZZLE D TOP NOZZLE D MIDDLE NOZZLE D BOTTOM NOZZLE C BOTTOM NOZZLE C SAMPLER BOTTOM NOZZLE D TOP NOZZLE D TOP NOZZLE C SAMPLER BOTTOM NOZZLE D 102 MIDDLE NOZZLE D 103 MIDDLE NOZZLE C 104 SAMPLER

TOP NOZZLE D 106 BOTTOM NOZZLE D 107 TOP NOZZLE C 108 MIDDLE NOZZLE D 109 BOTTOM NOZZLE D 110 MIDDLE NOZZLE C 111 BOTTOM NOZZLE D 112 MIDDLE NOZZLE C 113 MIDDLE NOZZLE C 114 BOTTOM NOZZLE C 115 SAMPLER

TOP NOZZLE D 117 BOTTOM NOZZLE D 118 TOP NOZZLE D 119 MIDDLE NOZZLE D 120 TOP NOZZLE C 121 TOP NOZZLE D 122 MIDDLE NOZZLE C 123 SAMPLER 124 BOTTOM NOZZLE D 125 BOTTOM NOZZLE D 126

\begin{tabular}{|c|c|}
\hline $\begin{array}{l}\text { MIDDLE } \\
\text { TOP }\end{array}$ & $\begin{array}{l}\text { NOZZLE } \\
\text { NOZZLE }\end{array}$ \\
\hline MIDDLE & NOZZLE $C$ \\
\hline MIDDLE & NOZZLE \\
\hline MIDDLE & NOZZLE C \\
\hline TOP & NOZZLE $\mathrm{C}$ \\
\hline BотTOM & NOZZLE C \\
\hline BOTTOM & NOZZLE C \\
\hline BOTTOM & NOZZLE C \\
\hline $\begin{array}{l}\text { IUP } \\
\text { SAMPLER }\end{array}$ & NOLLLE \\
\hline BOTTOM & NOZZLE D \\
\hline TOP & NOZZLE C \\
\hline MIDDLE & NOZZLE C \\
\hline SAMPLER & \\
\hline BOTTOM & NOZZLE D \\
\hline TOP & NOZZLE C \\
\hline TOP & NOZZLE C \\
\hline MIDDLE & NOZZLE D \\
\hline TOP & NOZZLE D \\
\hline TOP & NOZZLE D \\
\hline SAMPLER & \\
\hline MIDDLE & NOZZLE C \\
\hline MIDDLE & NOZZLE \\
\hline BOTTOM & NOZZLE D \\
\hline MIDDLE & NOZZLE D \\
\hline TOP & NOZZLE D \\
\hline BOTTOM & NOZZLE D \\
\hline $\begin{array}{l}\text { BOTTOM } \\
\text { SAMPLER }\end{array}$ & NOZZLE C \\
\hline TOP & NOZZLE D \\
\hline TOP & NOZZLE D \\
\hline MIDDLE & NOZZLE \\
\hline TOP & NOZZLE D \\
\hline ВотTOM & NOZZLE D \\
\hline TOP & NOZZLE D \\
\hline BOTTOM & NOZZLE C \\
\hline MIDDLE & NOZZLE D \\
\hline MIDDLE & NOZZLE D \\
\hline BOTTOM & MOZZLE D \\
\hline BOTTOM & NOZZLE \\
\hline TOP & NOZZLE \\
\hline
\end{tabular}

Order

127 128

129

130

131

132

133

134

135

136

137

138

139

140

141

142

143

144

145

146

147

148

149

150

151

152

153

154
Location

BOTTOM NOZZLE D SAMPLER

TOP NOZZLE C

MIDDLE NOZZLE D

BOTTOM NOZZLE D

MIDDLE NOZZLE D SAMPLER

BOTTOM NOZZLE C TOP NOZZLE C TOP NOZZLE TOP NOZZLE D BOTTOM NOZZLE $C$ SAMPLER MIDDLE NOZZLE D BOTTOM NOZZLE D TOP NOZZLE D MIDDLE NOZZLE D MIDDLE NOZZLE D SAMPLER BOTTOM NOZZLE C TOP NOZZLE $C$ MIDDLE NOZZLE C SAMPLER MIDDLE NOZZLE D BOTTOM NOZZLE D SAMPLER BOTTOM NOZZLE C MIDDLE NOZZLE D

(a) See Figure 4.1.

(b) "Sampler" refers to Liquid Sampling System. 
TABLE A.3. Sampling Order for the Homogeneity and Sampling System Test Using the Dilute Melter Feed Slurry

\begin{tabular}{|c|c|c|}
\hline Order & Locat & $\operatorname{tion}^{(a)}$ \\
\hline 1 & TOP & NOZZLE C \\
\hline 2 & MIDDLE & NOZZLE C \\
\hline 3 & ВОттом & NOZZLE C \\
\hline 4 & Воттом & NOZZLE C \\
\hline 5 & ВОтTOM & NOZZLE D \\
\hline 6 & TOP & NOZZLE C \\
\hline 7 & TOP & NOZZLE C \\
\hline 8 & воттом & NOZZLE C \\
\hline 9 & TOP & NOZZLE D \\
\hline 10 & MIDDLE & NOZZLE C \\
\hline 11 & Воттом & NOZZLE D \\
\hline 12 & ВотTOM & NOZZLE C \\
\hline 13 & TOP & NOZZLE C \\
\hline 14 & MIDDLE & NOZZLE D \\
\hline 15 & TOP & NOZZLE D \\
\hline 16 & ВОTTOM & NOZZLE C \\
\hline 17 & TOP & NOZZLE D \\
\hline 18 & MIDDLE & NOZZLE D \\
\hline 19 & MIDDLE & NOZZLE C \\
\hline 20 & TOP & NOZZLE C \\
\hline & $\begin{array}{l}\text { BOTTOM } \\
\text { SAMPLER }\end{array}$ & (b)ZZLE D \\
\hline 23 & воттом & NOZZLE C \\
\hline 24 & ВоTTOM & NOZZLE D \\
\hline 25 & MIDDLE & NOZZLE C \\
\hline 26 & ВотTOM & NOZZLE D \\
\hline 27 & SAMPLER & \\
\hline 28 & MIDDLE & NOZZLE \\
\hline 29 & ВОтTOM & NOZZLE \\
\hline 30 & MIDDLE & NOZZLE $C$ \\
\hline 31 & MIDDLE & NOZZLE C \\
\hline 32 & воттом & NOZZLE D \\
\hline 33 & ВотTOM & NOZZLE $C$ \\
\hline 34 & MIDDLE & NOZZLE D \\
\hline 35 & BOTTOM & NOZZLE C \\
\hline 36 & MIDDLE & NOZZLE C \\
\hline 37 & MIDDLE & NOZZLE D \\
\hline 38 & TOP & NOZZLE \\
\hline 39 & TOP & NOZZLE D \\
\hline 40 & SAMPLER & \\
\hline & воттом & NOZZLE \\
\hline & TOP & NOZZLE \\
\hline
\end{tabular}

\begin{tabular}{|c|c|c|c|}
\hline der & Loca & ation & Ord \\
\hline $\begin{array}{l}43 \\
44\end{array}$ & $\begin{array}{l}\text { BOTTOM } \\
\text { SAMPLER }\end{array}$ & NOZZLE D & \\
\hline 45 & MIDDLE & NOZZLE C & \\
\hline $\begin{array}{l}46 \\
47\end{array}$ & $\begin{array}{l}\text { BOTTON } \\
\text { SAMPLER }\end{array}$ & NOZZLE & \\
\hline 48 & TOP & NOZZLE D & \\
\hline 59 & MIDDLE & NOZZLE D & \\
\hline 50 & TOP & NOZZLE & \\
\hline 51 & SAMPLER & & \\
\hline 52 & BOTTOM & NOZZLE D & \\
\hline 53 & SAMPLER & & \\
\hline 54 & MIDDLE & NOZZLE C & \\
\hline 55 & TOP & & \\
\hline 56 & воттом & NOZZLE & \\
\hline 57 & MIDDLE & NOZZLE D & \\
\hline 58 & BOTTOM & NOZZLE & \\
\hline 59 & ВОTTOM & NOZZLE D & \\
\hline 60 & MIDDLE & NOZZLE D & \\
\hline 61 & SAMPLER & & \\
\hline 62 & MIDDLE & NOZZLE C & \\
\hline 63 & ВотTOM & NOZZLE & \\
\hline 64 & ВотTOM & NOZZLE C & \\
\hline 65 & TOP & NOZZLE D & \\
\hline 66 & $T O P$ & NOZZLE D & \\
\hline 67 & $T O P$ & NOZZLE & \\
\hline 68 & SAMPLER & & \\
\hline 69 & TOP & NOZZLE D & \\
\hline 70 & TOP & NOZZLE & \\
\hline 71 & ВотTOM & NOZZLE & \\
\hline 72 & ВОТTOM & NOZZLE D & \\
\hline 73 & SAMPLER & & \\
\hline 74 & MIDDLE & NOZZLE C & \\
\hline 75 & MIDDLE & NOZZLE & \\
\hline 76 & BOTTOM & NOZZLE & \\
\hline 77 & SAMPLER & & \\
\hline 78 & MIDDLE & NOZZLE C & \\
\hline 79 & ВОтТОМ & NOZZLE & \\
\hline 80 & SAMPLER & & \\
\hline 81 & MIDDLE & NOZZLE D & \\
\hline 82 & TOP & NOZZLE & \\
\hline 83 & TOP & NOZZLE & \\
\hline 8 & MIDDLE & NOZZLE D & \\
\hline
\end{tabular}

\begin{tabular}{ll}
\multicolumn{2}{c}{ LOCaTION } \\
\hline BOTTOM & NOZZLE C \\
SAMPLER & \\
BOTTOM & NOZZLE D \\
TOP & NOZZLE D \\
TOP & NOZZLE C \\
BOTTOM & NOZZLE C \\
BOTTOM & NOZZLE $~$ \\
TOP & NOZZLE C \\
SAMPLER & \\
MIDDLE & NOZZLE D \\
MIDDLE & NOZZLE D \\
MIDDLE & NOZZLE C \\
BOTTOM & NOZZLE D \\
BOTTOM & NOZZLE D \\
BOTTOM & NOZZLE D \\
SAMPLER & \\
BOTTOM & NOZZLE C \\
MIDDLE & NOZZLE C \\
MIDDLE & NOZZLE C \\
SAMPLER & \\
BOTTOM & NOZZLE D \\
TOP & NOZZLE D \\
TOP & NOZZLE C \\
TOP & NOZZLE C \\
MIDDLE & NOZZLE C \\
TOP & NOZZLE C \\
TOP & NOZZLE D \\
SAMPLER & \\
MIDDLE & NOZZLE C \\
BOTTOM & NOZZLE C \\
TOP & NOZZLE C \\
MIDDLE & NOZZLE D \\
TOP & NOZZLE D \\
TOP & NOZZLE C \\
MIDDLE & NOZZLE D \\
TOP & NOZZLE D \\
MIDDLE & NOZZLE D \\
TOP & NOZZLE C \\
TOP & NOZZLE C \\
SAMPLER & \\
TOP & NOZZLE D \\
MIDDLE & NOZZLE D \\
&
\end{tabular}
Order $\frac{\text { Location }}{\text { TOP NOZZLE D }}$ $\begin{array}{lll}127 & \text { TOP } & \text { NOZZLE D } \\ 128 & \text { BOTTOM } & \text { NOZZLE C }\end{array}$ 129 TOP NOZZLE D 130 SAMPLER

131 TOP NOZZLE C 132 TOP NOZZLE C 133 MIDDLE NOZZLE C 134 BOTTOM NOZZLE D 135 BOTTON NOZZLE D 136 MIDDLE NOZZLE D 137 BOTTOM NOZZLE C 138 SAMPLER

139 MIDDLE NOZZLE D 140 TOP NOZZLE D 141 BOTTOM NOZZLE C 142 SAMPLER

143 TOP NOZZLE D 144 MIDDLE NOZZLE C 145 TOP NOZZLE C 146 MIDDLE NOZZLE D 147 MIDDLE NOZZLE C 148 MIDDLE NOZZLE C 149 BOTTOM NOZZLE C 150 SAMPLER

151 MIDDLE NOZZLE D

152 MIDDLE NOZZLE D

153 MIDDLE NOZZLE D 154 TOP NOZZLE D

(a) See figure 4.1.

(b) "Sampler" refers to Liquid Sampl ing System. 
TABLE A.4. Sampling Order for the Resuspension Test Using the Concentrated Melter Feed Slurry

\begin{tabular}{|c|c|c|c|c|c|c|c|c|}
\hline \multicolumn{3}{|c|}{2 Hour Wait-Time. } & \multicolumn{3}{|c|}{6 Hour Wait-Time } & \multicolumn{3}{|c|}{24 Hour Wait-Time } \\
\hline Order & Loca & on (a) & order & $\mathrm{LO}$ & ation & Order & $\mathrm{LOC}$ & ation \\
\hline 155 & ВОТТОМ & NOZZLE C & 197 & BOTTOM & NOZZLE C & 239 & BOTTOM & NOZZLE C \\
\hline 156 & TOP & NOZZLE C & 198 & MIDDLE & NOZZLE C & 240 & TOP & NOZZLE C \\
\hline 157 & TOP & NOZZLE C & 199 & MIDDLE & NOZZLE D & 241 & TOP & NOZZLE C \\
\hline 158 & MIDDLE & NOZZLE D & 200 & TOP & NOZZLE C & 242 & MIDDLE & NOZZLE D \\
\hline 159 & MIDDLE & NOZZLE C & 201 & TOP & NOZZLE C & 243 & MIDDLE & NOZZLE C \\
\hline 160 & TOP & NOZZLE D & 202 & ВОТТОМ & NOZZLE C & 244 & TOP & NOZZLE D \\
\hline 161 & TOP & NOZZLE D & 203 & TOP & NOZZLE C & 245 & TOP & NOZZLE D \\
\hline 162 & TOP & NOZZLE D & 204 & TOP & NOZZLE D & 246 & TOP & NOZZLE D \\
\hline 163 & ВОТТОМ & NOZZLE D & 205 & ВОТТОМ & NOZZLE D & 247 & ВОТTOM & NOZZLE D \\
\hline 164 & TOP & NOZZLE D & 206 & MIDDLE & NOZZLE D & 248 & TOP & NOZZLE D \\
\hline 165 & MIDDLE & NOZZLE D & 207 & ВОТТОМ & NOZZLE D & 249 & MIDDLE & NOZZLE D \\
\hline 166 & TOP & NOZZLE C & 208 & MIDDLE & NOZZLE C & 250 & TOP & NOZZLE C \\
\hline 167 & TOP & NOZZLE D & 209 & MIDDLE & NOZZLE D & 251 & TOP & NOZZLE D \\
\hline 168 & ВОТTOM & NOZZLE D & 210 & TOP & NOZZLE C & 252 & ВОТTOM & NOZZLE D \\
\hline 169 & ВОTTOM & NOZZLE C & 211 & ВОTTOM & NOZZLE C & 253 & BOTTOM & NOZZLE C \\
\hline 170 & ВОTТОМ & NOZZLE C & 212 & ВОTTOM & NOZZLE C & 254 & BOTTOM & NOZZLE C \\
\hline 171 & MIDDLE & NOZZLE C & 213 & MIDDLE & NOZZLE D & 255 & MIDDLE & NOZZLE C \\
\hline 172 & ВОТТОМ & NOZZLE C & 214 & ВОТТОМ & NOZZLE D & 256 & BOTTOM & NOZZLE C \\
\hline 173 & MIDDLE & NOZZLE C & 215 & TOP & NOZZLE D & 257 & MIDDLE & NOZZLE C \\
\hline 174 & BOTTOM & NOZZLE C & 216 & TOP & NOZZLE C & 258 & ВOTTOM & NOZZLE C \\
\hline 175 & BOTTOM & NOZZLE C & 217 & TOP & NOZZLE D & 259 & ВОТТОМ & NOZZLE C \\
\hline 176 & MIDDLE & NOZZLE C & 218 & MIDDLE & NOZZLE D & 260 & MIDDLE & NOZZLE C \\
\hline 177 & ВОTTOM & NOZZLE D & 219 & MIDDLE & NOZZLE C & 261 & ВОТТОМ & NOZZLE D \\
\hline 178 & TOP & NOZZLE C & 220 & TOP & NOZZLE C & 262 & TOP & NOZZLE C \\
\hline 179 & MIDDLE & NOZZLE D & 221 & TOP & NOZZLE D & 263 & MIDDLE & NOZZLE D \\
\hline & ВОТТОМ & NOZZLE D & 222 & ВОТТОМ & NOZZLE D & 264 & ВОТТОМ & NOZZLE D \\
\hline & MIDDLE & NOZZLE C & 223 & MIDDLE & NOZZLE D & 26 & MIDDLE & NOZZLE C \\
\hline & MIDDLE & NOZZLE C & 224 & TOP & NOZZLE D & & MIDDLE & NOZZLE C \\
\hline & MIDDLE & NOZZLE D & 225 & ВОТТОМ & NOZZLE D & 267 & MIDDLE & NOZZLE D \\
\hline & MIDDLE & NOZZLE C & 226 & TOP & NOZZLE C & 26 & MIDDLE & NOZZLE C \\
\hline & TOP & NOZZLE C & 227 & MIDDLE & NOZZLE C & 26 & TOP & NOZZLE C \\
\hline & ВОТTOM & NOZZLE D & 228 & TOP & NOZZLE D & 27 & ВОTTOM & NOZZLE D \\
\hline & TOP & NOZZLE C & 229 & MIDDLE & NOZZLE D & & TOP & NOZZLE C \\
\hline & ВОТТОМ & NOZZLE C & & ВОТTOM & NOZZLE D & & BOTTOM & NOZZLE C \\
\hline & ВОТТОМ & NOZZLE D & 23 & TOP & NOZZLE D & & ВОТTOM & NOZZLE D \\
\hline & MIDDLE & NOZZLE D & 232 & MIDDLE & NOZZLE C & & MIDDLE & NOZZLE D \\
\hline & & NOZZLE D & & ВОТTOM & NOZZLE C & & TOP & NOZZLE D \\
\hline & MIDDLE & NOZZLE D & & ВОТТОМ & NOZZLE D & & MIDDLE & NOZZLE D \\
\hline & ВОТТОМ & NOZZLE D & 23 & ВОТТОМ & NOZZLE C & & BOTTOM & NOZZLE D \\
\hline & MIDDLE & NOZZLE D & & MIDDLE & NOZZLE C & & MIDDLE & NOZZLE D \\
\hline & TOP & NOZZLE D & & MIDDLE & NOZZLE C & & TOP & NOZZLE D \\
\hline & TOP & NOZZLE C & & ВОТТОМ & NOZZLE C & & TOP & NOZZLE C \\
\hline
\end{tabular}

(a) See Figure 4.1. 
TABLE A.5. Sampling Order for the Resuspension Test Using the Reference Melter Feed Siurry

2 Hour Wait-Time order Location(a)

155 MIDDLE NOZZLE D

156 MIDDLE NOZZLE D

157

158

159

160

161

162

163

164

165

166

167

168

169

170

171

172

173

174

175

176

177

178

179

180

181

182

183

184

185

186

187

188

189

190

191

192

193

194

195

196
BOTTOM NOZZLE C 199

BOTTOM NOZZLE C 200

MIDDLE NOZZLE C 201

MIDDLE NOZZLE C 202

MIDDLE NOZZLE C 203

BOTTOM NOZZLE D 204

BOTTOM NOZZLE D 205

MIDDLE NOZZLE D 206

MIDDLE NOZZLE C 207

BOTTOM NOZZLE C 208

TOP

NOZZLE D

MIDDLE NOZZLE D

BOTTOM NOZZLE C

MIDDLE NOZZLE C

TOP

TOP

TOP

MIDDLE

MIDDLE

TOP

BOTTOM

TOP

TOP

MIDDLE

BOTTOM

TOP

BOTTOM

TOP

BOTTOM

BOTTOM

TOP

TOP

MIDDLE

TOP

BOTTOM

BOTTOM

MIDDLE

BOTTOM

TOP

TOP
NOZZLE D

NOZZLE C

NOZZLE C

NOZZLE D

NOZZLE C

NOZZLE D

NOZZLE C

NOZZLE C

NOZZLE D

NOZZLE D

NOZZLE D

NOZZLE C

NOZZLE C

NOZZLE D

NOZZLE D

NOZZLE C

NOZZLE D

NOZZLE D

NOZZLE D

NOZZLE C

NOZZLE D

NOZZLE D

NOZZLE C

NOZZLE D

NOZZLE C

NOZZLE C
209

210

211

212

213

214

215

216

217

218

219

220

221

222

223

224

225

226

227

228

229

230

231

232

233

234

235

236

237

238
6 Hour Wait-Time Order Location
TOP

BOTTOM

BOTTOM

BOTTOM

BOTTOM

TOP

BOTTOM

MIDDLE

TOP

MIDDLE

TOP

TOP

MIDDLE

TOP

BOTTOM

MIDDLE

MIDDLE

TOP

BOTTOM

MIDDLE

BOTTOM

MIDDLE

TOP

BOTTOM

MIDDLE

TOP

MIDDLE

TOP

TOP

TOP

TOP

MIDDLE

MIDDLE

BOTTOM

BOTTOM

BOTTOM

BOTTOM

TOP

MIDDLE

MIDDLE

BOTTOM

MIDDLE
NOZZLE C

NOZZLE D

NOZZLE D

NOZZLE D

NOZZLE C

NOZZLE C

NOZZLE D

NOZZLE D

NOZZLE C

NOZZLE C

NOZZLE D

NOZZLE D

NOZZLE D

NOZZLE C

NOZZLE C

NOZZLE C

NOZZLE C

NOZZLE D

NOZZLE D

NOZZLE C

NOZZLE C

NOZZLE D

NOZZLE D

NOZZLE D

NOZZLE D

NOZZLE C

NOZZLE C

NOZZLE D

NOZZLE C

NOZZLE C

NOZZLE D

NOZZLE C

NOZZLE D

NOZZLE C

NOZZLE C

NOZZLE D

NOZZLE C

NOZZLE D

NOZZLE D

NOZZLE D

NOZZLE C NOZZLE C
24 Hour Wait-Time order Location

239

MIDDLE NOZZLE D

240 MIDDLE NOZZLE D

241 BOTTOM NOZZLE C

242 BOTTOM NOZZLE C

243 MIDDLE NOZZLE C

244 MIDDLE NOZZLE C

245

246

247

248

249

250

251

252

253

254

255

256

257

258

259

260

261

262

263

264

265

266

267

268

269

270

271

272

273

274

275

276

277

278

279

280

MIDDLE NOZZLE C

BOTTOM NOZZLE D

BOTTOM NOZZLE D

MIDDLE NOZZLE D

MIDDLE NOZZLE C

BOTTOM NOZZLE C

TOP NOZZLE D

MIDDLE NOZZLE D

BOTTOM NOZZLE C

MIDDLE NOZZLE C 
TABLE A.6. Sampling Order for the Resuspension Test Using the Dilute Melter Feed Slurry

\begin{tabular}{|c|c|c|c|c|c|c|c|c|}
\hline \multicolumn{3}{|c|}{2 Hour Wait-Time. } & \multicolumn{3}{|c|}{6 Hour Wait-Time } & \multicolumn{3}{|c|}{24 Hour Wait-Time } \\
\hline Order & Loca & ion (a) & Order & Lo & ation & order & Lo & tion \\
\hline 155 & ВОТTOM & NOZZLE C & 197 & ВОТTOM & NOZZLE C & 239 & BOTTOM & NOZZLE C \\
\hline 156 & TOP & NOZZLE C & 198 & BOTTOM & NOZZLE C & 240 & TOP & NOZZLE C \\
\hline 157 & BOTTOM & NOZZLE D & 199 & TOP & NOZZLE D & 241 & BOTTOM & NOZZLE D \\
\hline 158 & TOP & NOZZLE D & 200 & MIDDLE & NOZZLE D & 242 & TOP & NOZZLE D \\
\hline 159 & TOP & NOZZLE D & 201 & MIDDLE & NOZZLE C & 243 & TOP & NOZZLE D \\
\hline 160 & ВОТTOM & NOZZLE D & 202 & BOTTOM & NOZZLE D & 244 & BOTTOM & NOZZLE D \\
\hline 161 & MIDDLE & NOZZLE C & 203 & TOP & NOZZLE C & 245 & MIDDLE & NOZZLE \\
\hline 162 & MIDDLE & NOZZLE C & 204 & MIDDLE & NOZZLE D & 246 & MIDDLE & NOZZLE C \\
\hline 163 & MIDDLE & NOZZLE D & 205 & MIDDLE & NOZZLE D & 247 & MIDDLE & NOZZLE D \\
\hline 164 & TOP & NOZZLE D & 206 & MIDDLE & NOZZLE C & 248 & TOP & NOZZLE \\
\hline 165 & TOP & NOZZLE C & 207 & MIDDLE & NOZZLE D & 249 & TOP & NOZZLE \\
\hline 166 & ВОТTOM & NOZZLE C & 208 & TOP & NOZZLE D & 250 & BOTTOM & NOZZLE C \\
\hline 167 & BOTTOM & NOZZLE D & 209 & ВОТTOM & NOZZLE C & 251 & BOTTOM & NOZZLE D \\
\hline 168 & ВОТТОМ & NOZZLE D & 210 & TOP & NOZZLE C & 252 & BOTTOM & NOZZLE D \\
\hline 169 & TOP & NOZZLE C & 211 & ВОТTOM & NOZZLE C & 253 & TOP & NOZZLE C \\
\hline 170 & TOP & NOZZLE C & 212 & MIDDLE & NOZZLE C & 254 & TOP & NOZZLE C \\
\hline 171 & TOP & NOZZLE D & 213 & BOTTOM & NOZZLE D & 255 & TOP & NOZZLE D \\
\hline 172 & TOP & NOZZLE C & 214 & MIDDLE & NOZZLE D & 256 & TOP & NOZZLE C \\
\hline 173 & MIDDLE & NOZZLE C & 215 & MIDDLE & NOZZLE C & 257 & MIDDLE & NOZZLE C \\
\hline 174 & ВОТТОМ & NOZZLE D & 216 & BOTTOM & NOZZLE D & 258 & BOTTOM & NOZZLE D \\
\hline 175 & ВОТTOM & NOZZLE C & 217 & TOP & NOZZLE C & 259 & BOTTOM & NOZZLE C \\
\hline 176 & MIDDLE & NOZZLE D & 218 & MIDDLE & NOZZLE C & 260 & MIDDLE & NOZZLE D \\
\hline 177 & MIDDLE & NOZZLE D & 219 & ВОТTOM & NOZZLE D & 261 & MIDDLE & NOZZLE D \\
\hline 178 & ВОТТОМ & NOZZLE C & 220 & BOTTOM & NOZZLE C & 262 & ВОТТОМ & NOZZLE \\
\hline 179 & ВОТТОМ & NOZZLE C & 221 & TOP & NOZZLE D & 263 & ВОТTОМ & NOZZLE C \\
\hline 180 & MIDDLE & NOZZLE D & 222 & TOP & NOZZLE C & 264 & MIDDLE & NOZZLE D \\
\hline 181 & ВОТТОМ & NOZZLE D & 223 & TOP & NOZZLE D & 265 & BOTTOM & NOZZLE D \\
\hline 182 & MIDDLE & NOZZLE C & 224 & TOP & NOZZLE C & 266 & MIDDLE & NOZZLE \\
\hline 183 & TOP & NOZZLE D & 225 & TOP & NOZZLE D & 267 & TOP & NOZZLE \\
\hline 184 & MIDDLE & NOZZLE D & 226 & MIDDLE & NOZZLE C & 268 & MIDDLE & NOZZLE \\
\hline 185 & TOP & NOZZLE C & 227 & TOP & NOZZLE C & 269 & TOP & NOZZLE C \\
\hline 186 & TOP & NOZZLE D & 228 & MIDDLE & NOZZLE D & 270 & TOP & NOZZLE \\
\hline 187 & ВОТТОМ & NOZZLE D & 229 & ВОTTOM & NOZZLE D & 2 & ВОТТОМ & NOZZLE \\
\hline 188 & ВOTTOM & NOZZLE C & 230 & TOP & NOZZLE D & 272 & BOTTOM & NOZZLE C \\
\hline 189 & TOP & NOZZLE D & 231 & MIDDLE & NOZZLE C & 273 & TOP & NOZZLE D \\
\hline 190 & MIDDLE & NOZZLE D & 232 & TOP & NOZZLE D & 274 & MIDDLE & NOZZLE \\
\hline 191 & MIDDLE & NOZZLE C & 233 & BOTTOM & NOZZLE C & 275 & MIDDLE & NOZZLE \\
\hline 19 & MIDDLE & NOZZLE C & 234 & ВОTTOM & NOZZLE D & 276 & MIDDLE & NOZZLE C \\
\hline 19 & TOP & NOZZLE C & 23 & MIDDLE & NOZZLE D & 277 & TOP & NOZZLE C \\
\hline 19 & MIDDLE & NOZZLE D & & TOP & NOZZLE C & 278 & MIDDLE & NOZZLE D \\
\hline 19 & MIDDLE & NOZZLE C & & ВОТTОМ & NOZZLE D & 279 & MIDDLE & NOZZLE C \\
\hline 196 & ВОТТОМ & NOZZLE C & 238 & ВОТТОМ & NOZZLE C & 280 & ВОТТОМ & NOZZLE \\
\hline
\end{tabular}

(a) See Figure 4.1. 
TABLE A.7. Sample Analysis Order for the Homogeneity and Sampling System Test Using the Concentrated Melter Feed Slurry

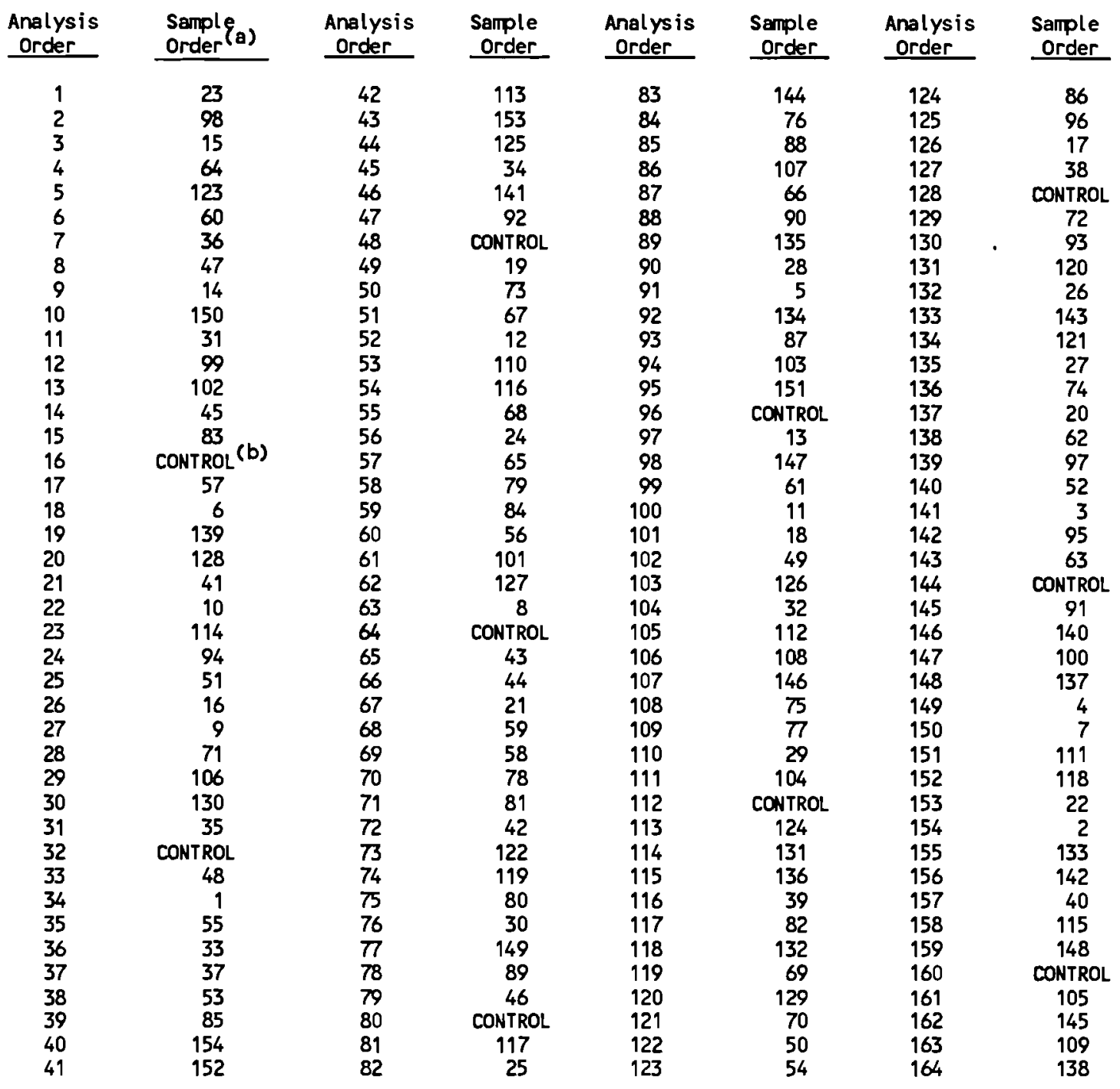

(a) See Table A.1 for description of sample locations.

(b) A $250 \mathrm{ml}$ sample was taken during the Homogeneity and Sampl ing System Test using the concentrated melter feed slurry. Al iquots from this sample were analyzed every 16 th sample to determine if long-term analytical effects existed. 
TABLE A.8. Sample Analysis Order for the Homogeneity and Sampling System Test Using the Reference Melter Feed Slurry

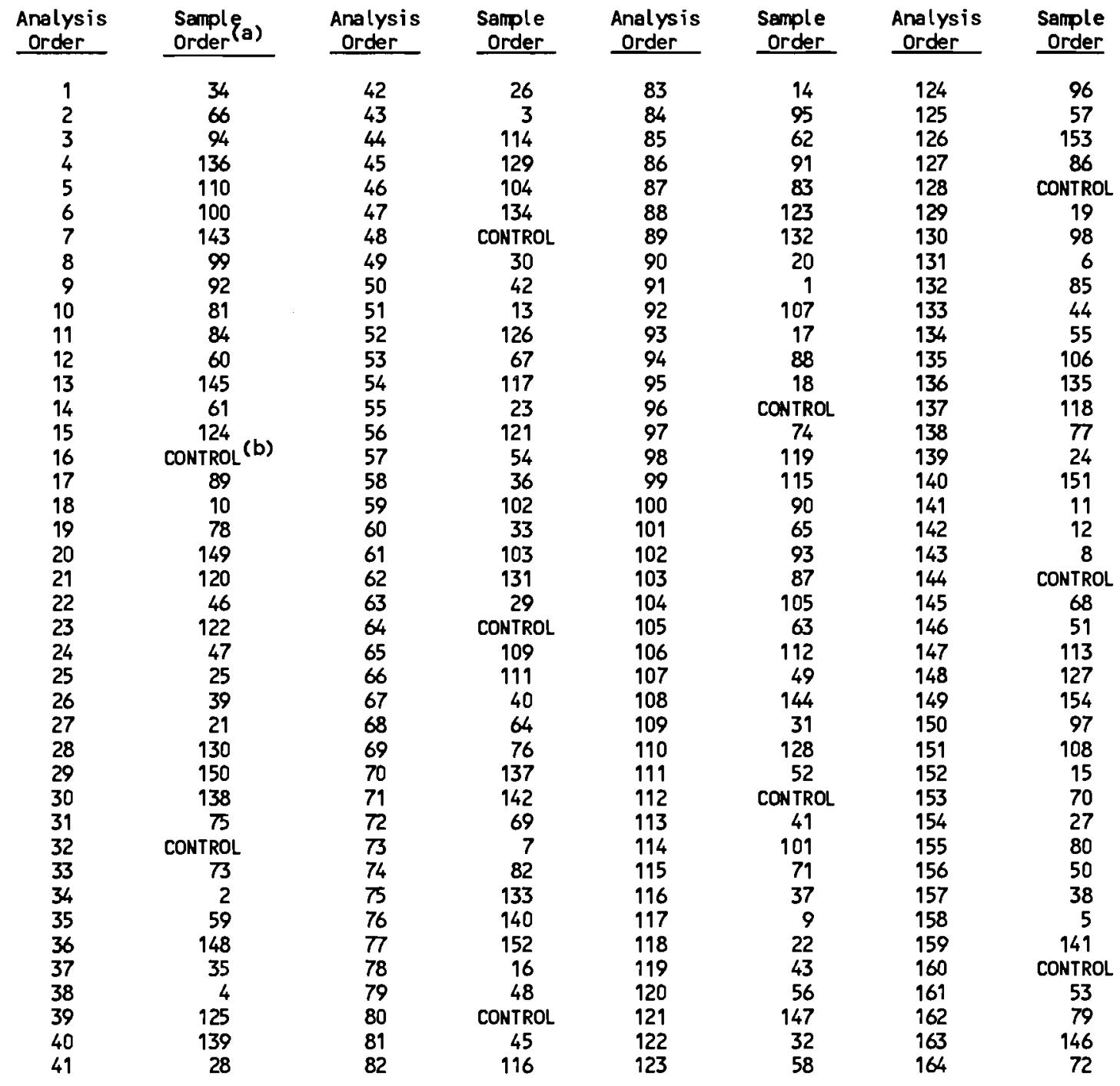

(a) See Table A.2 for description of sample locations.

(b) A $250 \mathrm{ml}$ sample was taken during the Homogeneity and Sampling System Test using the concentrated melter feed slurry. Aliquots from this sample were analyzed every 16th sample to determine if long-term analytical effects existed. 
TABLE A.9. Sample Analysis Order for the Homogeneity and Sampling System Test Using the Dilute Melter Feed Slurry

\begin{tabular}{|c|c|c|c|c|c|c|c|}
\hline $\begin{array}{l}\text { Analysis } \\
\text { Order }\end{array}$ & $\begin{array}{l}\text { Sample } \\
\text { Order }\end{array}$ & $\begin{array}{c}\text { Analys is } \\
\text { Order }\end{array}$ & $\begin{array}{c}\text { Sample } \\
\text { Order }\end{array}$ & $\begin{array}{l}\text { Analys is } \\
\text { Order }\end{array}$ & $\begin{array}{l}\text { Sample } \\
\text { Order }\end{array}$ & $\begin{array}{l}\text { Analysis } \\
\text { Order }\end{array}$ & $\begin{array}{l}\text { Sample } \\
\text { Order }\end{array}$ \\
\hline $\begin{array}{r}1 \\
2 \\
3 \\
4 \\
5 \\
6 \\
7 \\
8 \\
9 \\
10 \\
11 \\
12 \\
13 \\
14 \\
15 \\
16 \\
17 \\
18 \\
19 \\
20 \\
21 \\
22 \\
23 \\
24 \\
25 \\
26 \\
27 \\
28 \\
29 \\
30 \\
31 \\
32 \\
33 \\
34 \\
35 \\
36 \\
37 \\
38 \\
39 \\
40 \\
41\end{array}$ & 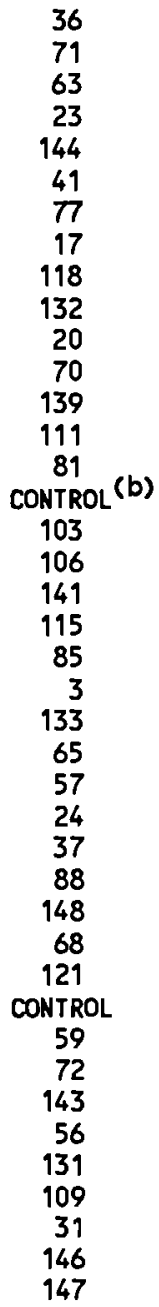 & $\begin{array}{l}42 \\
43 \\
44 \\
45 \\
46 \\
47 \\
48 \\
49 \\
50 \\
51 \\
52 \\
53 \\
54 \\
55 \\
56 \\
57 \\
58 \\
59 \\
60 \\
61 \\
62 \\
63 \\
64 \\
65 \\
66 \\
67 \\
68 \\
69 \\
70 \\
71 \\
72 \\
73 \\
74 \\
75 \\
76 \\
77 \\
78 \\
79 \\
80 \\
81 \\
82\end{array}$ & $\begin{array}{c}61 \\
79 \\
120 \\
107 \\
114 \\
140 \\
\text { CONTROL } \\
91 \\
101 \\
142 \\
112 \\
122 \\
12 \\
95 \\
10 \\
151 \\
128 \\
9 \\
97 \\
30 \\
80 \\
119 \\
\text { CONTROL } \\
153 \\
108 \\
110 \\
38 \\
137 \\
87 \\
99 \\
154 \\
135 \\
113 \\
32 \\
116 \\
83 \\
62 \\
100 \\
\text { CONTROL } \\
34 \\
4\end{array}$ & $\begin{array}{l}83 \\
84 \\
85 \\
86 \\
87 \\
88 \\
89 \\
90 \\
91 \\
92 \\
93 \\
94 \\
95 \\
96 \\
97 \\
98 \\
99 \\
100 \\
101 \\
102 \\
103 \\
104 \\
105 \\
106 \\
107 \\
108 \\
109 \\
110 \\
111 \\
112 \\
113 \\
114 \\
115 \\
116 \\
117 \\
118 \\
119 \\
120 \\
121 \\
122 \\
123\end{array}$ & $\begin{array}{c}8 \\
130 \\
82 \\
1 \\
16 \\
75 \\
125 \\
22 \\
45 \\
127 \\
54 \\
98 \\
60 \\
\text { CONTRO } \\
47 \\
102 \\
13 \\
18 \\
5 \\
46 \\
67 \\
42 \\
39 \\
48 \\
40 \\
40 \\
25 \\
94 \\
149 \\
55 \\
\text { CONTR } \\
96 \\
14 \\
7 \\
105 \\
19 \\
152 \\
64 \\
29 \\
136 \\
51\end{array}$ & $\begin{array}{l}124 \\
125 \\
126 \\
127 \\
128 \\
129 \\
130 \\
131 \\
132 \\
133 \\
134 \\
135 \\
136 \\
137 \\
138 \\
139 \\
140 \\
141 \\
142 \\
143 \\
144 \\
145 \\
146 \\
147 \\
148 \\
149 \\
150 \\
151 \\
152 \\
153 \\
154 \\
155 \\
156 \\
157 \\
158 \\
159 \\
160 \\
161 \\
162 \\
163 \\
164\end{array}$ & $\begin{array}{c}43 \\
90 \\
78 \\
52 \\
\text { CONTROL } \\
89 \\
150 \\
145 \\
129 \\
117 \\
74 \\
76 \\
73 \\
92 \\
50 \\
124 \\
93 \\
2 \\
15 \\
86 \\
\text { CONTROL } \\
49 \\
126 \\
11 \\
27 \\
44 \\
6 \\
53 \\
104 \\
28 \\
69 \\
84 \\
58 \\
33 \\
134 \\
138 \\
\text { CONTROL } \\
66 \\
26 \\
123 \\
35\end{array}$ \\
\hline
\end{tabular}

(a) See Table A.2 for description of sample locations.

(b) A $250 \mathrm{ml}$ sample was taken during the Homogeneity and Sampl ing System Test using the concentrated melter feed slurry. Al iquots from this sample were analyzed every 16 th sample to determine if long-term analytical effects existed. 
TABLE A.10. Sample Analysis Order for the Resuspension Tests Using the Concentrated Me1ter Feed Slurry

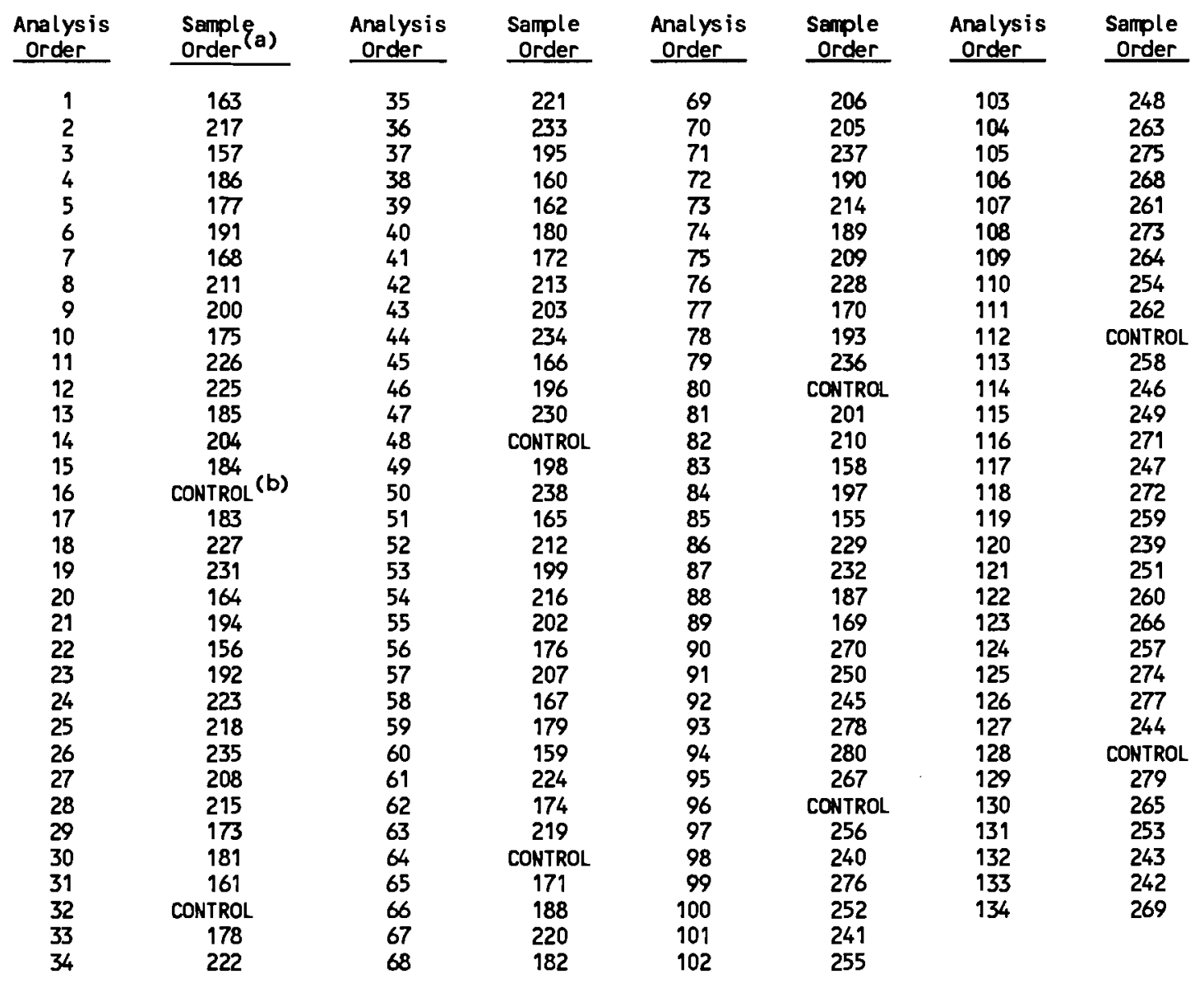

(a) See Table A.1 for description of sample locations.

(b) A $250 \mathrm{ml}$ sample was taken during the Homogeneity and Sampl ing System Test using the concentrated melter feed slurry. Al iquots from this sample were analyzed every 16 th sample to determine if long-term analytical effects existed. 


\section{TABLE A.11. Sample Analysis Order for the Resuspension Test Using the Reference Meiter Feed Slurry}

\begin{tabular}{|c|c|c|c|c|c|c|c|}
\hline $\begin{array}{l}\text { Analysis } \\
\text { Order }\end{array}$ & $\begin{array}{l}\text { Sample (a) } \\
\text { Order }\end{array}$ & $\begin{array}{l}\text { Analysis } \\
\text { Order }\end{array}$ & $\begin{array}{c}\text { Sample } \\
\text { Order }\end{array}$ & $\begin{array}{l}\text { Analys is } \\
\text { Order }\end{array}$ & $\begin{array}{l}\text { Sample } \\
\text { Order }\end{array}$ & $\begin{array}{l}\text { Analysis } \\
\text { Order }\end{array}$ & $\begin{array}{c}\text { Sample } \\
\text { Order }\end{array}$ \\
\hline $\begin{array}{l}1 \\
2 \\
3 \\
4 \\
5 \\
6 \\
7 \\
8 \\
9 \\
10 \\
11 \\
12 \\
13 \\
14 \\
15 \\
16 \\
17 \\
18 \\
19 \\
20 \\
21 \\
22 \\
23 \\
24 \\
25 \\
26 \\
27 \\
28 \\
29 \\
30 \\
31 \\
32 \\
33 \\
34\end{array}$ & $\begin{array}{c}191 \\
178 \\
197 \\
230 \\
179 \\
169 \\
224 \\
162 \\
211 \\
199 \\
212 \\
213 \\
185 \\
155 \\
221 \\
\text { CONTROL (b) } \\
226 \\
176 \\
206 \\
187 \\
163 \\
236 \\
231 \\
160 \\
225 \\
184 \\
237 \\
180 \\
227 \\
166 \\
234 \\
\text { CONTROL } \\
201 \\
219\end{array}$ & $\begin{array}{l}35 \\
36 \\
37 \\
38 \\
39 \\
40 \\
41 \\
42 \\
43 \\
44 \\
45 \\
46 \\
47 \\
48 \\
49 \\
50 \\
51 \\
52 \\
53 \\
54 \\
55 \\
56 \\
57 \\
58 \\
59 \\
60 \\
61 \\
62 \\
63 \\
64 \\
65 \\
66 \\
67 \\
68\end{array}$ & $\begin{array}{l}193 \\
214 \\
173 \\
159 \\
203 \\
233 \\
161 \\
200 \\
223 \\
216 \\
174 \\
181 \\
194 \\
\text { CONTROL } \\
218 \\
202 \\
207 \\
238 \\
186 \\
156 \\
182 \\
196 \\
220 \\
168 \\
172 \\
192 \\
183 \\
217 \\
215 \\
\text { CONTROL } \\
177 \\
232 \\
205 \\
209\end{array}$ & $\begin{array}{l}69 \\
70 \\
71 \\
72 \\
73 \\
74 \\
75 \\
76 \\
77 \\
78 \\
79 \\
80 \\
81 \\
82 \\
83 \\
84 \\
85 \\
86 \\
87 \\
88 \\
89 \\
90 \\
91 \\
92 \\
93 \\
94 \\
95 \\
96 \\
97 \\
98 \\
99 \\
100 \\
101 \\
102\end{array}$ & $\begin{array}{l}195 \\
189 \\
167 \\
235 \\
204 \\
228 \\
198 \\
229 \\
170 \\
165 \\
188 \\
\text { CONTROL } \\
222 \\
210 \\
157 \\
208 \\
190 \\
164 \\
175 \\
171 \\
158 \\
279 \\
252 \\
268 \\
255 \\
263 \\
247 \\
\text { CONTROL } \\
276 \\
243 \\
246 \\
251 \\
257 \\
270\end{array}$ & $\begin{array}{l}103 \\
104 \\
105 \\
106 \\
107 \\
108 \\
109 \\
110 \\
111 \\
112 \\
113 \\
114 \\
115 \\
116 \\
117 \\
118 \\
119 \\
120 \\
121 \\
122 \\
123 \\
124 \\
125 \\
126 \\
127 \\
128 \\
129 \\
130 \\
131 \\
132 \\
133 \\
134\end{array}$ & $\begin{array}{c}266 \\
269 \\
273 \\
272 \\
275 \\
249 \\
254 \\
267 \\
258 \\
\text { CONTROL } \\
253 \\
264 \\
261 \\
242 \\
260 \\
278 \\
274 \\
245 \\
256 \\
277 \\
262 \\
240 \\
241 \\
265 \\
271 \\
\text { CONTROL } \\
248 \\
259 \\
244 \\
280 \\
239 \\
250\end{array}$ \\
\hline
\end{tabular}

(a) See Table A.2 for description of sample locations.

(b) A $250 \mathrm{ml}$ sample was taken during the Homogeneity and Sampl ing System Test using the concentrated melter feed slurry. Aliquots from this sample were analyzed every 16th sample to determine if long-term analytical effects existed. 
TABLE A.12. Sample Analysis Order for the Resuspension Test Using the Dilute Melter Feed Slurry

\begin{tabular}{|c|c|c|c|c|c|c|c|}
\hline $\begin{array}{l}\text { Analysis } \\
\text { Order }\end{array}$ & $\begin{array}{l}\text { Sample } \\
\text { Order }\end{array}$ & $\begin{array}{c}\text { Analysis } \\
\text { Order }\end{array}$ & $\begin{array}{c}\text { Sample } \\
\text { Order } \\
\end{array}$ & $\begin{array}{l}\text { Analys is } \\
\text { Order }\end{array}$ & $\begin{array}{c}\text { Sample } \\
\text { Order } \\
\end{array}$ & $\begin{array}{c}\text { Analysis } \\
\text { Order }\end{array}$ & $\begin{array}{l}\text { Sample } \\
\text { Order } \\
\end{array}$ \\
\hline $\begin{array}{r}1 \\
2 \\
3 \\
4 \\
5 \\
6 \\
7 \\
8 \\
9 \\
10 \\
11 \\
12 \\
13 \\
14 \\
15 \\
16 \\
17 \\
18 \\
19 \\
20 \\
21 \\
22 \\
23 \\
24 \\
25 \\
26 \\
27 \\
28 \\
29 \\
30 \\
31 \\
32 \\
33 \\
34\end{array}$ & $\begin{array}{c}160 \\
185 \\
231 \\
186 \\
206 \\
176 \\
237 \\
178 \\
218 \\
164 \\
159 \\
191 \\
238 \\
156 \\
188 \\
\text { CONTROL (b) } \\
212 \\
220 \\
196 \\
223 \\
234 \\
182 \\
165 \\
224 \\
181 \\
227 \\
201 \\
195 \\
211 \\
197 \\
236 \\
\text { CONTROL } \\
171 \\
167 \\
101\end{array}$ & $\begin{array}{l}35 \\
36 \\
37 \\
38 \\
39 \\
40 \\
41 \\
42 \\
43 \\
44 \\
45 \\
46 \\
47 \\
48 \\
49 \\
50 \\
51 \\
52 \\
53 \\
54 \\
55 \\
56 \\
57 \\
58 \\
59 \\
60 \\
61 \\
62 \\
63 \\
64 \\
65 \\
66 \\
67 \\
68\end{array}$ & $\begin{array}{c}173 \\
205 \\
219 \\
200 \\
210 \\
226 \\
221 \\
157 \\
225 \\
194 \\
172 \\
215 \\
217 \\
\text { CONTRO } \\
179 \\
190 \\
214 \\
163 \\
233 \\
192 \\
222 \\
187 \\
193 \\
174 \\
173 \\
229 \\
166 \\
168 \\
170 \\
\text { CONTRO } \\
158 \\
193 \\
193 \\
232 \\
183\end{array}$ & $\begin{array}{r}69 \\
70 \\
71 \\
72 \\
73 \\
74 \\
75 \\
76 \\
77 \\
78 \\
79 \\
80 \\
81 \\
82 \\
83 \\
84 \\
85 \\
86 \\
87 \\
88 \\
89 \\
90 \\
91 \\
92 \\
93 \\
94 \\
95 \\
96 \\
97 \\
98 \\
99 \\
100 \\
101 \\
102\end{array}$ & $\begin{array}{l}184 \\
177 \\
173 \\
230 \\
228 \\
216 \\
161 \\
199 \\
203 \\
180 \\
189 \\
\text { CONTROL } \\
202 \\
213 \\
162 \\
208 \\
155 \\
169 \\
207 \\
209 \\
235 \\
271 \\
250 \\
269 \\
261 \\
256 \\
263 \\
\text { CONTROL } \\
255 \\
248 \\
279 \\
262 \\
276 \\
247\end{array}$ & $\begin{array}{l}103 \\
104 \\
105 \\
106 \\
107 \\
108 \\
109 \\
110 \\
111 \\
112 \\
113 \\
114 \\
115 \\
116 \\
117 \\
118 \\
119 \\
120 \\
121 \\
122 \\
123 \\
124 \\
125 \\
126 \\
127 \\
128 \\
129 \\
130 \\
131 \\
132 \\
133 \\
134\end{array}$ & $\begin{array}{l}246 \\
259 \\
260 \\
265 \\
277 \\
252 \\
270 \\
278 \\
254 \\
\text { CONTROL } \\
264 \\
242 \\
272 \\
266 \\
273 \\
257 \\
243 \\
274 \\
241 \\
240 \\
244 \\
280 \\
258 \\
253 \\
245 \\
\text { CONTROL } \\
239 \\
275 \\
249 \\
267 \\
268 \\
251\end{array}$ \\
\hline
\end{tabular}

(a) See Table A.3 for description of sample locations.

(b) A $250 \mathrm{ml}$ sample was taken during the Homogeneity and Sampl ing System Test using the concentrated melter feed slurry. Al iquots from this sample were analyzed every 16th sample to determine if long-term analytical effects existed. 


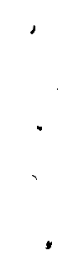




\section{APPENDIX B}

STATISTICAL ANALYSES RESULTS 

APPENDIX B

\section{STATISTICAL ANALYSES RESULTS}

Plots of the total solids or elemental weight percents after removing the effects of the factors studied in the experiment (residual plots) should resemble a random band of values when plotted by analytical order. However, as seen in the residual plots shown in Figures B.I through B.24, there are definite trends across analytical order. These long-term effects account for a sizable portion of the total analytical variation.

Plots of the analytical determinations for the control samples are shown in Figures B.25 through B.31. These plots also reveal the long-term analytical variation. The magnitude of the analytical uncertainty will directly affect the number of analyses that will be required during hot operations. If the analytical uncertainties can be reduced, the required number of feed analyses for characterization and waste form qualification purposes can be reduced. Moreover, if the analytical uncertainty is reduced, the cold chemical addition recipe will be more accurate, thereby improving the ability to produce a glass composition nearer the optimal target composition. The benefits gained by reducing the analytical uncertainty seem to warrant some effort towards such a reduction. 


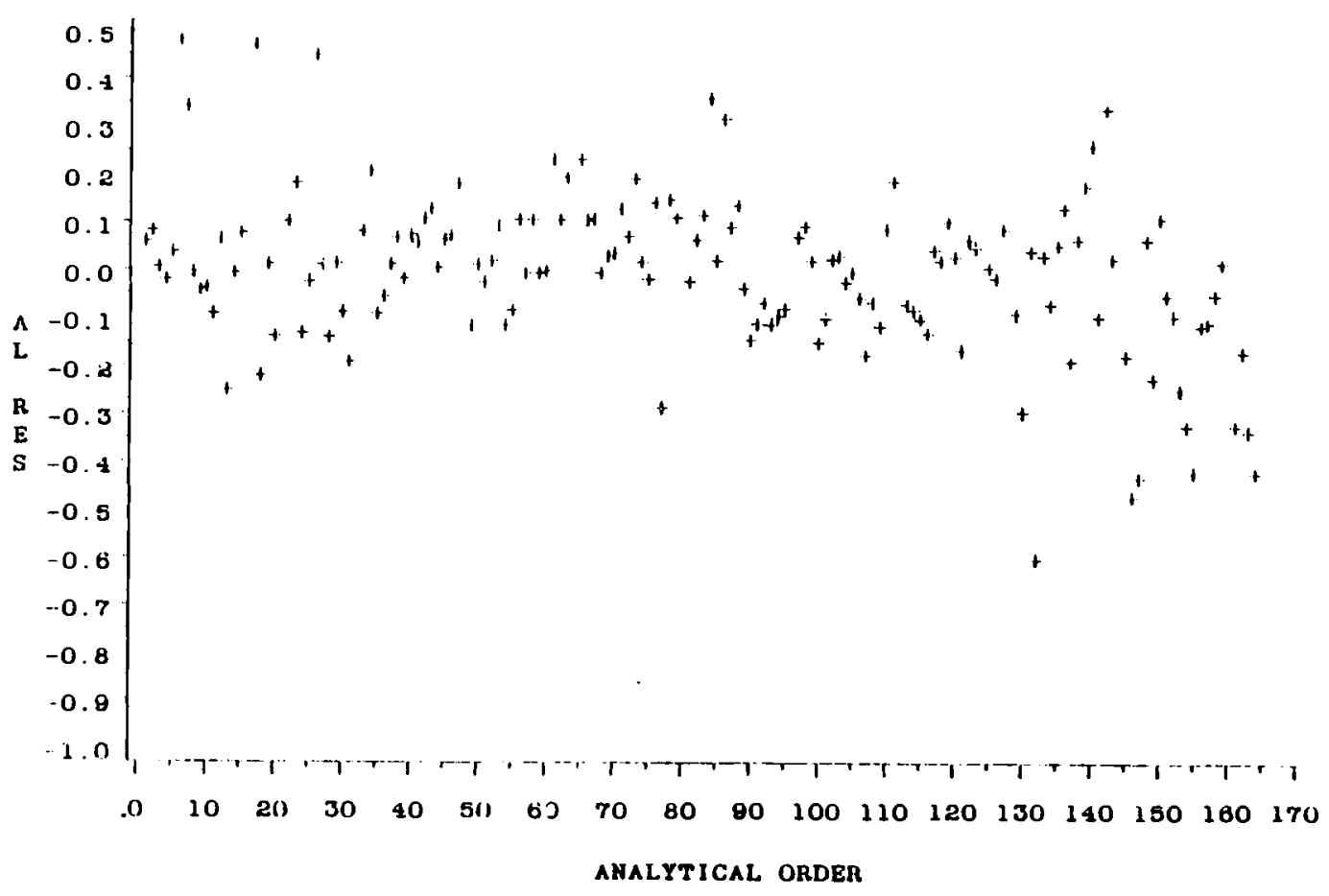

FIGURE B.1. Plot of Residuals Versus Analytical Order for Aluminum (A1) Homogeneity and Sampling System Test with Concentrated Melter Feed Slurry.

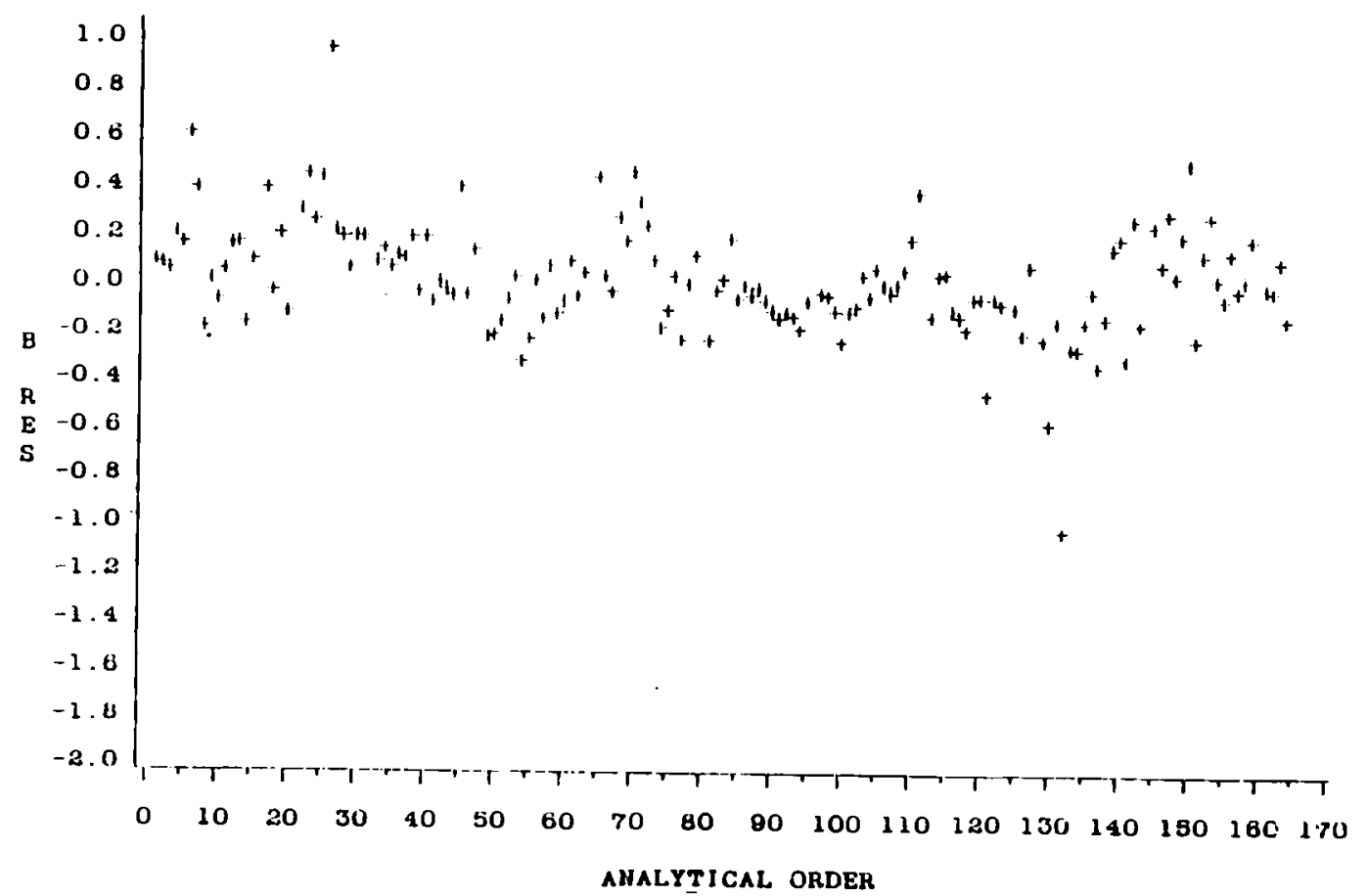

FIGURE B.2. Plot of Residuals Versus Analytical Order for Boron (B) Homogeneity and Sampling System Test with Concentrated Melter Feed Slurry. 


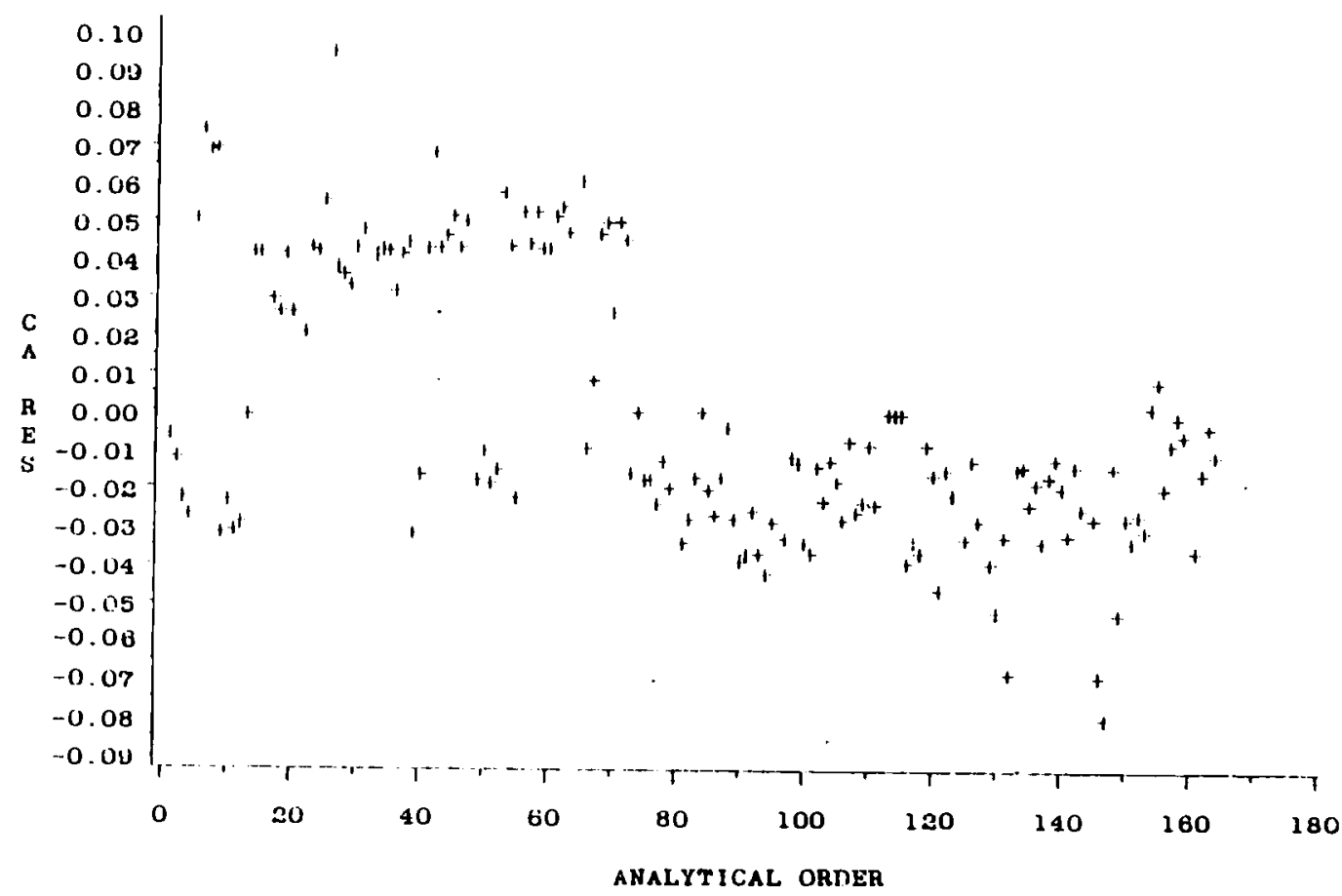

FIGURE B.3. Plot of Residuals Versus Analytical Order for Calcium (Ca) Homogeneity and Sampling System Test with Concentrated Melter Feed Slurry.

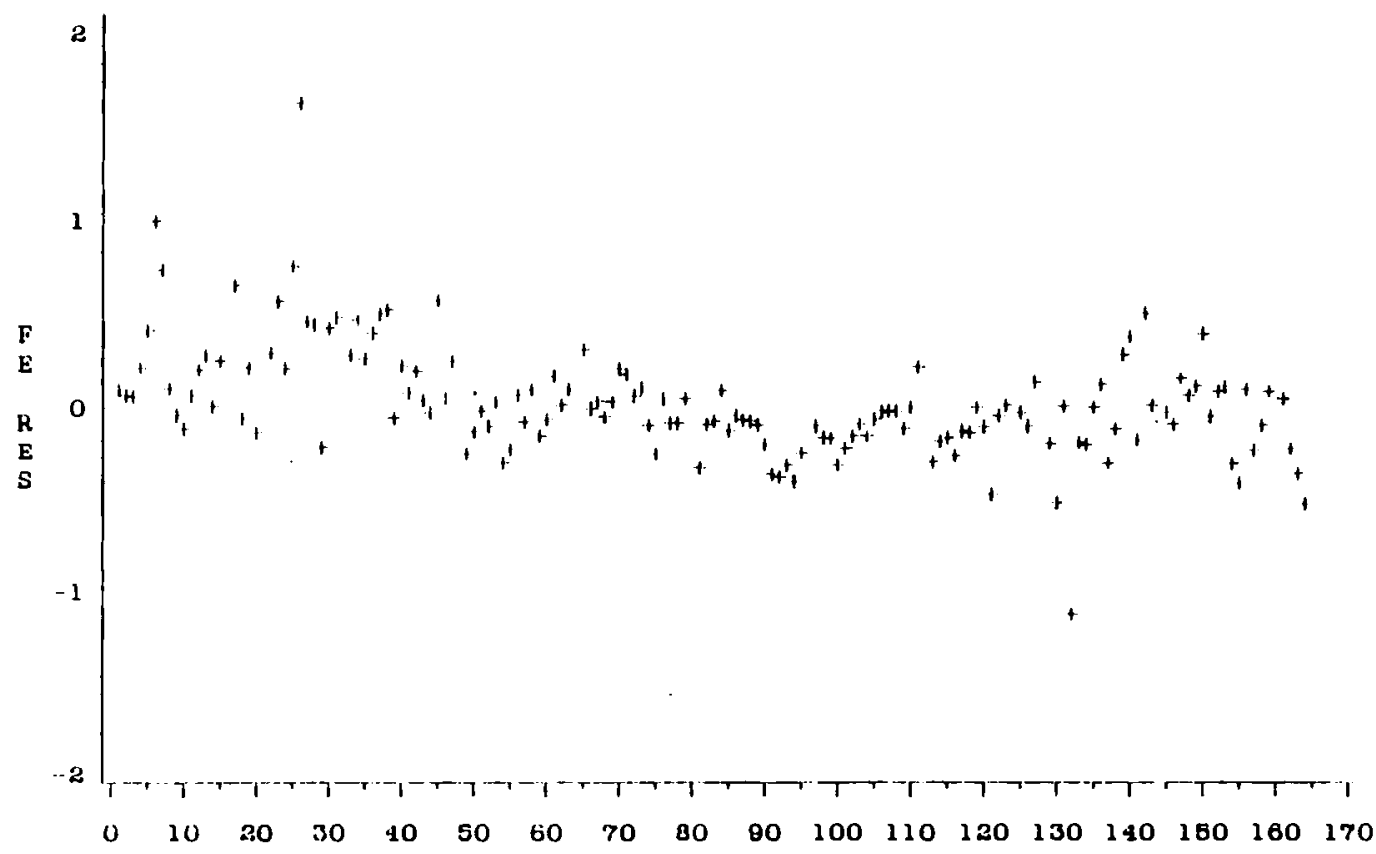

ANALYTICAL ORDER

FIGURE B.4. Plot of Residuals Versus Analytical Order for Iron (Fe) Homogeneity and Sampling System Test with Concentrated Melter Feed Slurry. 


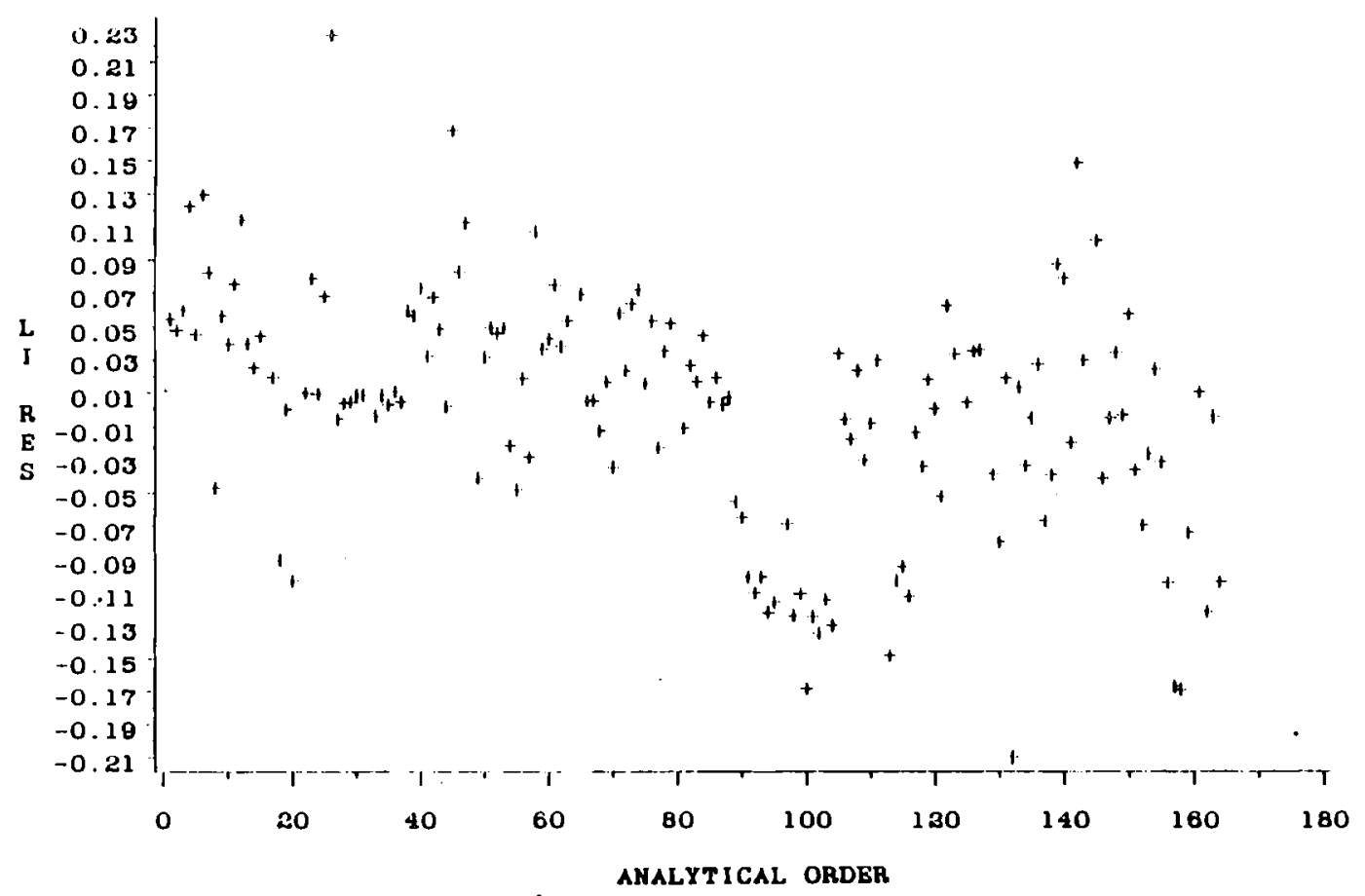

FIGURE B.5. Plot of Residuals Versus Analytical Order for Lithium (Li) Homogeneity and Sampling System Test with Concentrated Melter Feed Slurry.

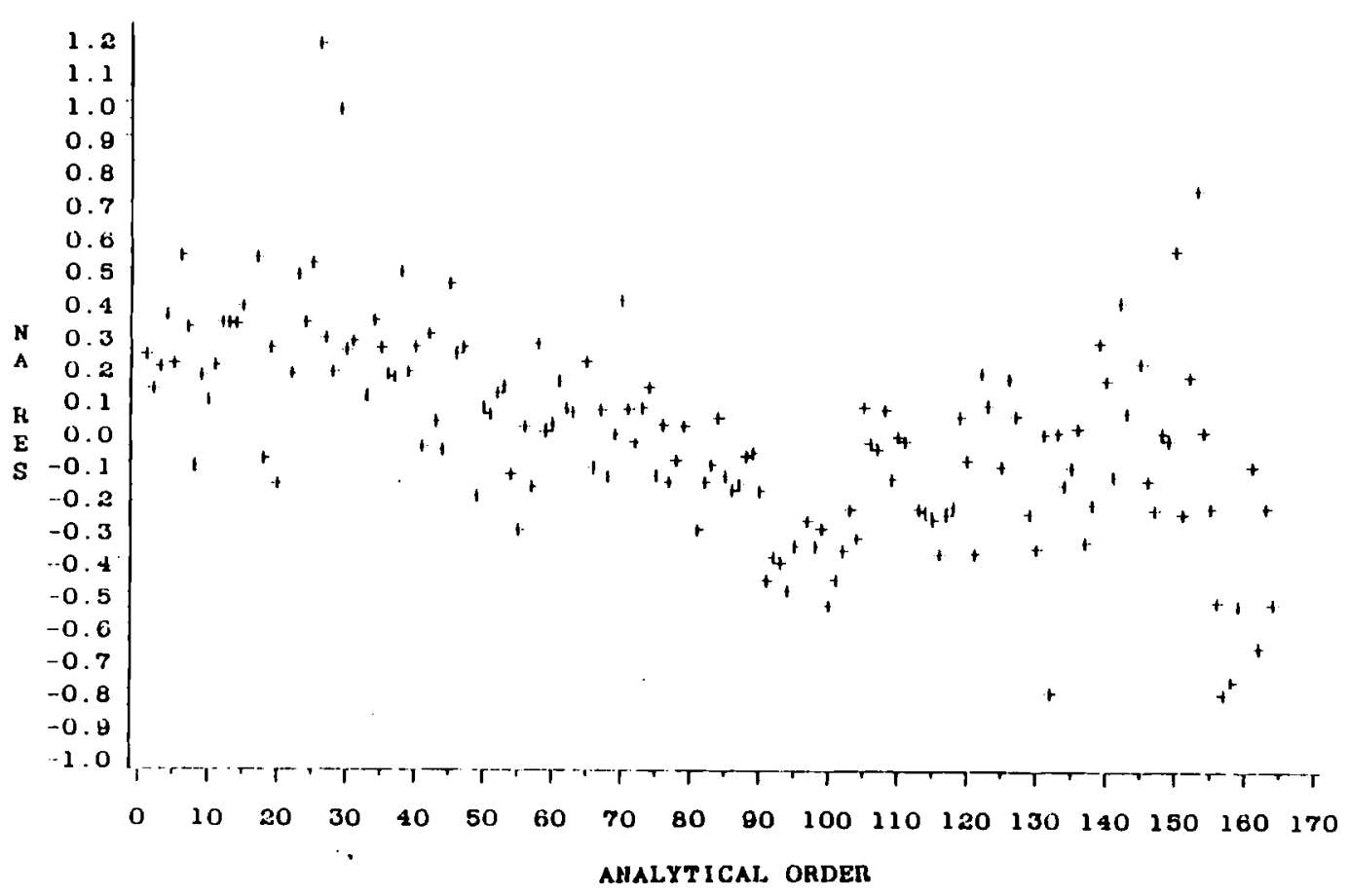

FIGURE B.6. Plot of Residuals Versus Analytical Order for Sodium (Na) Homogeneity and Sampling System Test with Concentrated Melter Feed Slurry. 


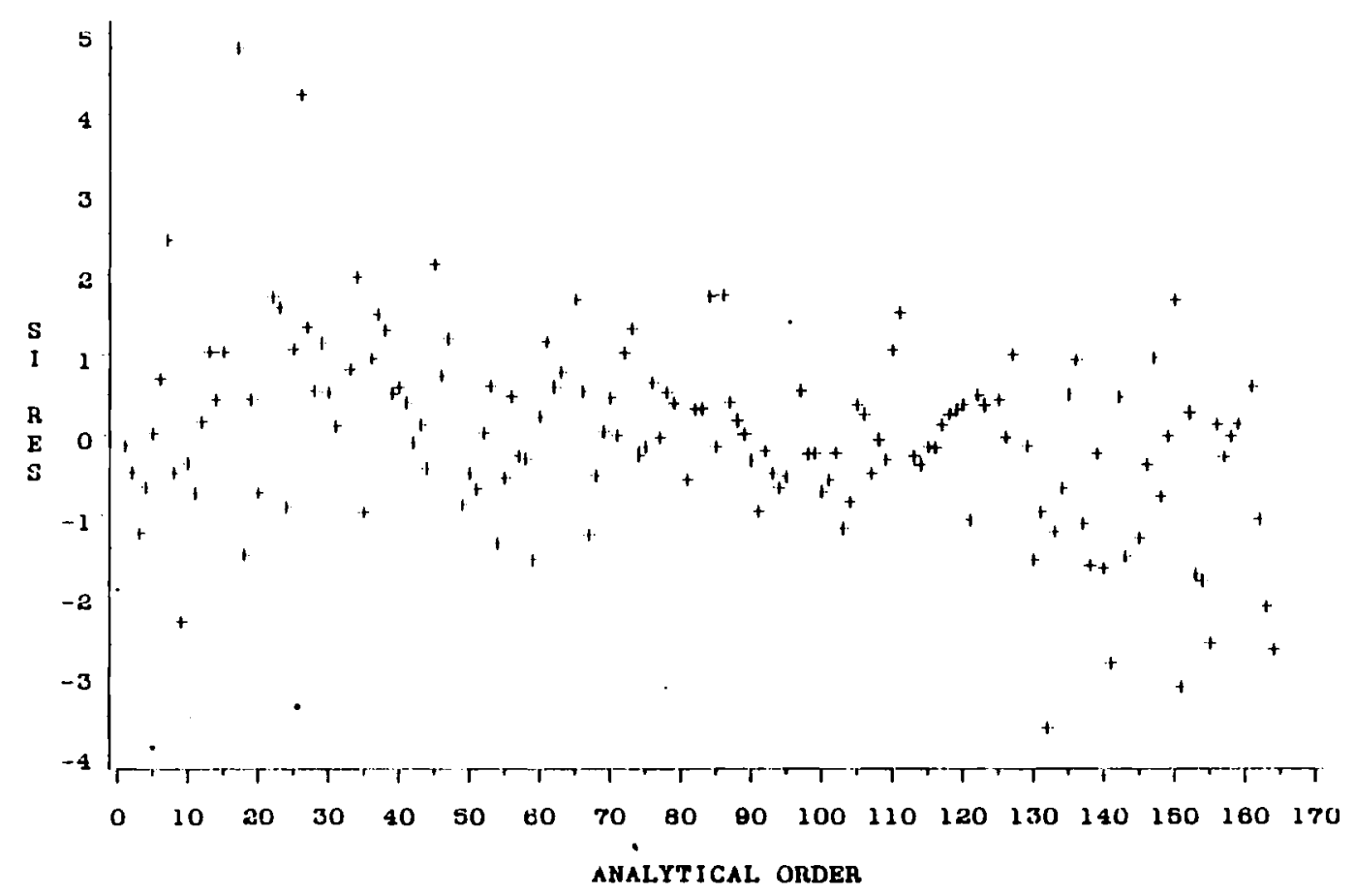

FIGURE B.7. Plot of Residuals Versus Analytical Order for Silica (Si) Homogeneity and Sampling System Test with Concentrated Melter Feed Slurry.

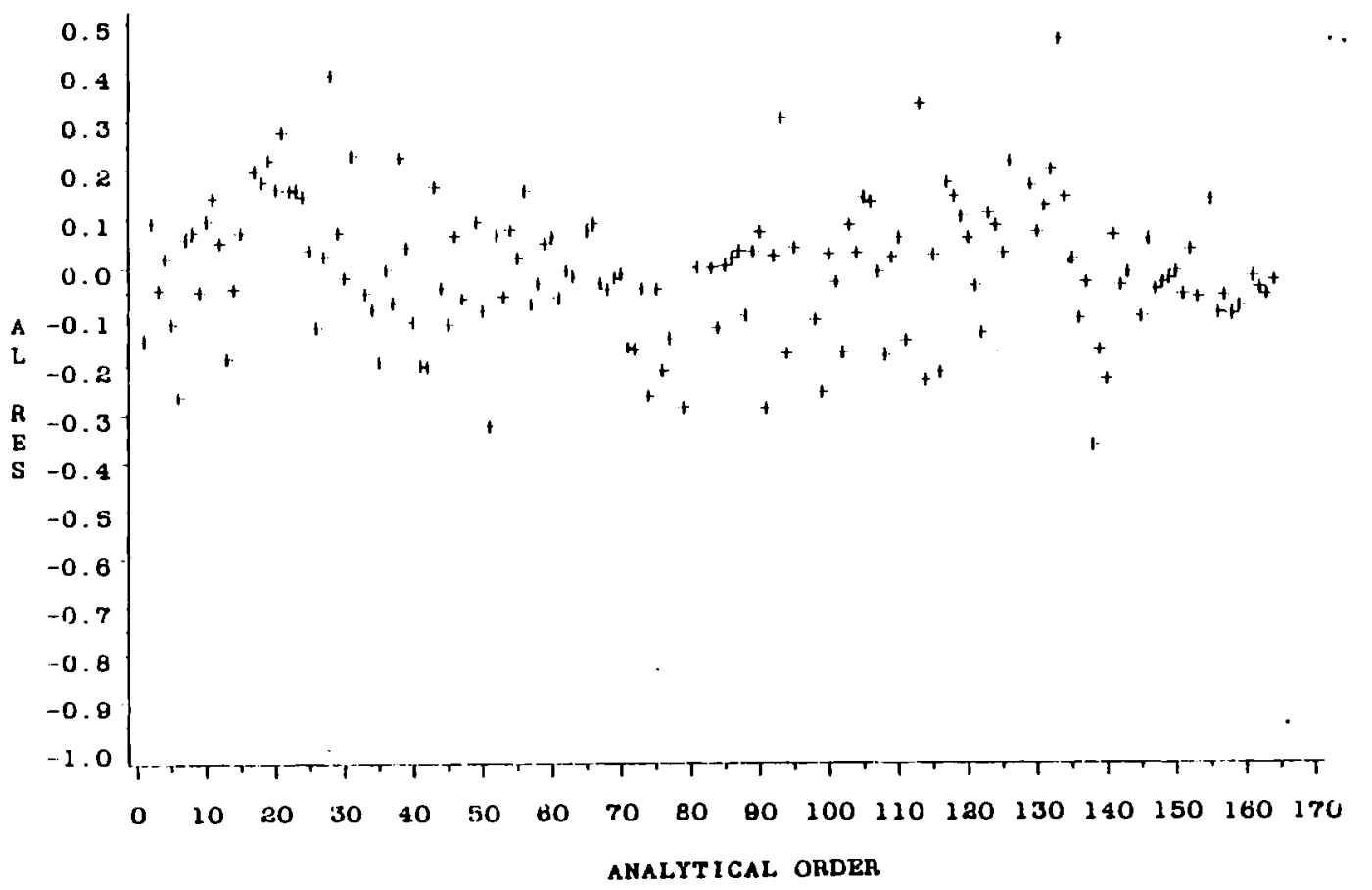

FIGURE B.8. Plot of Residuals Versus Analytical Order for Aluminum (A1) Homogeneity and Sampling System Test with Reference Melter Feed Slurry. 


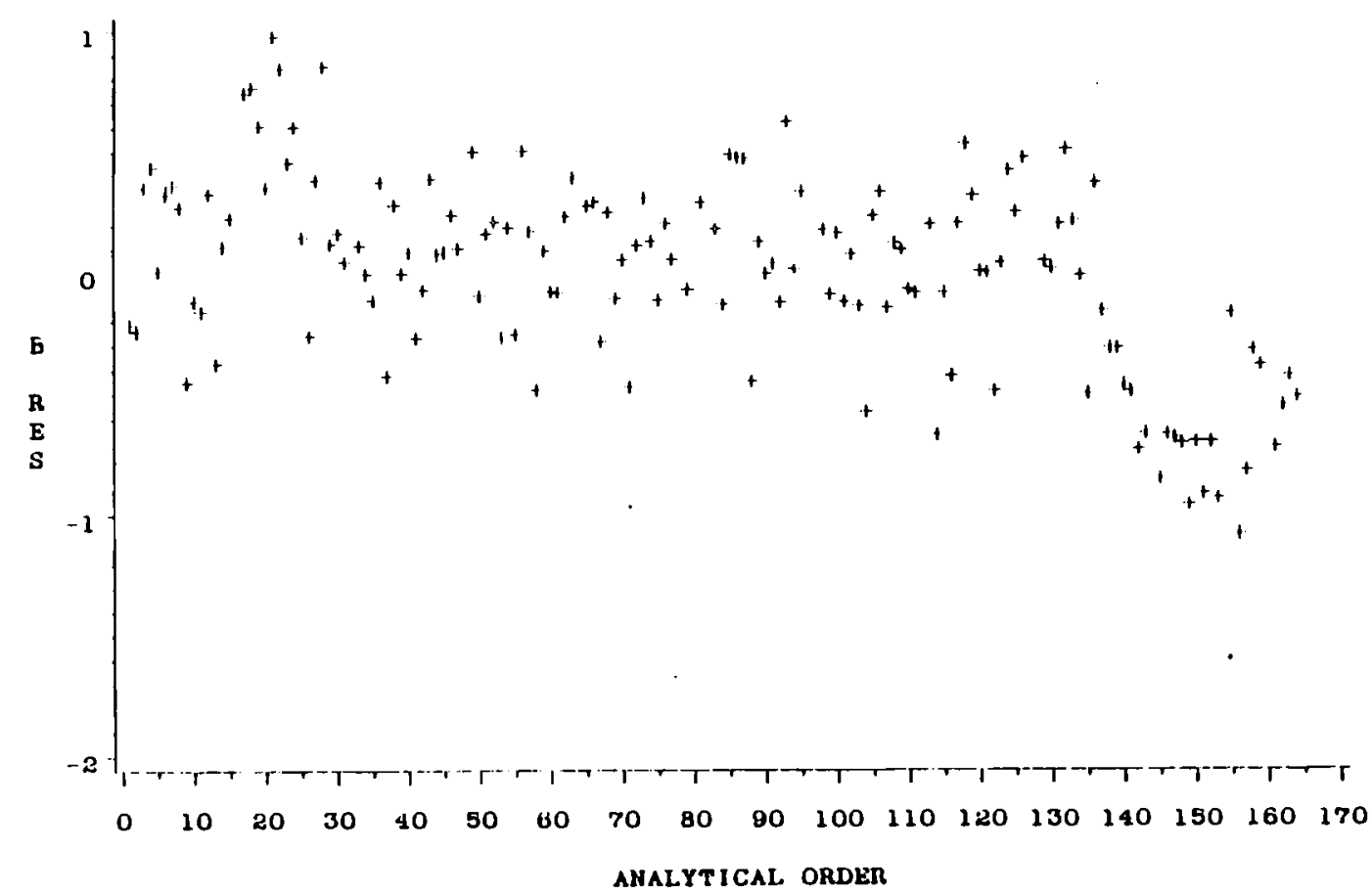

FIGURE B.9. Plot of Residuals Versus Analytical Order for Boron (B) Homogeneity and Sampling System Test with Reference Melter Feed Slurry.

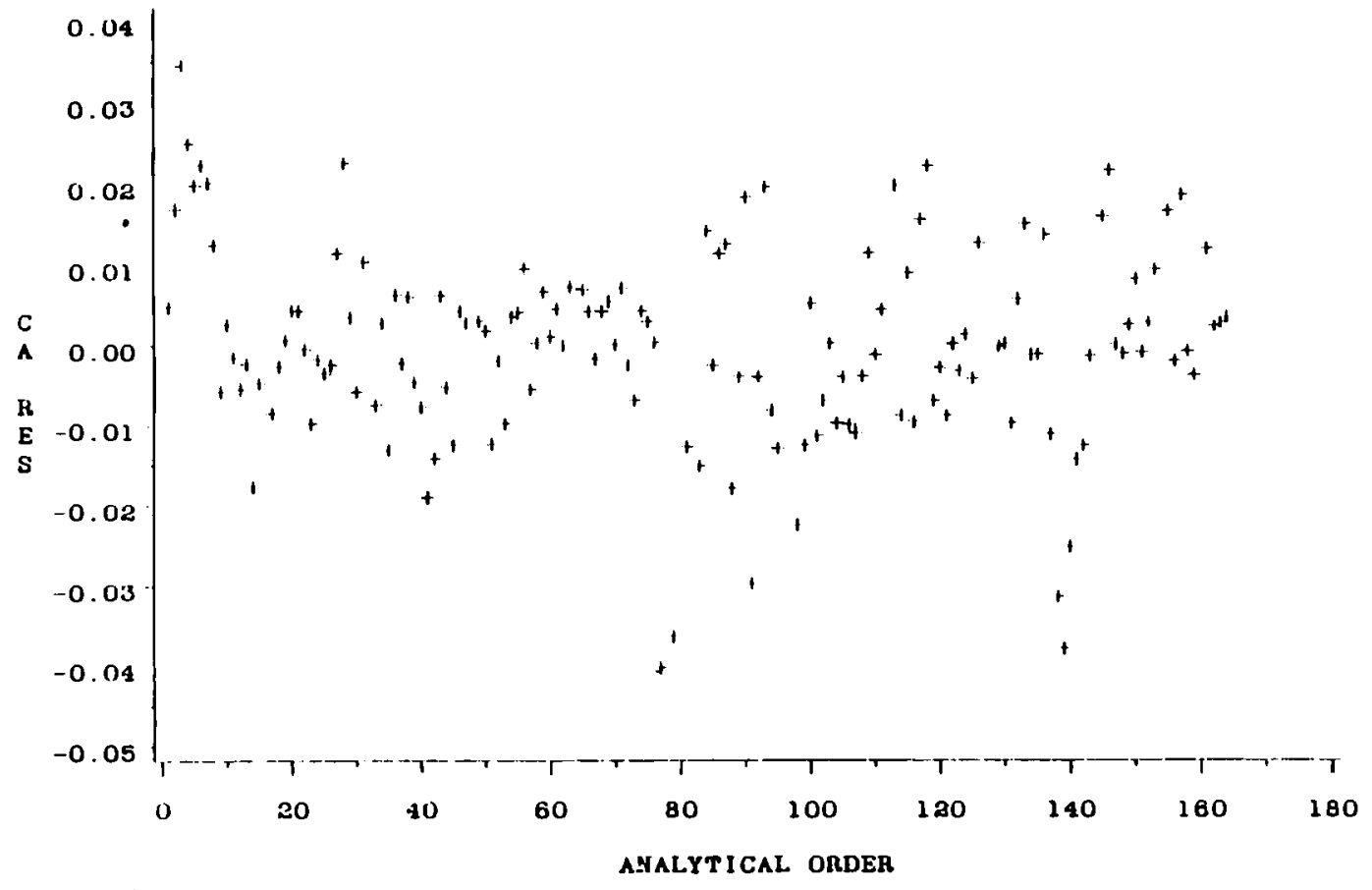

FIGURE B.10. Plot of Residuals Versus Analytical Order for Calcium (Ca) Homogeneity and Sampling System Test with Reference Melter Feed Slurry. 


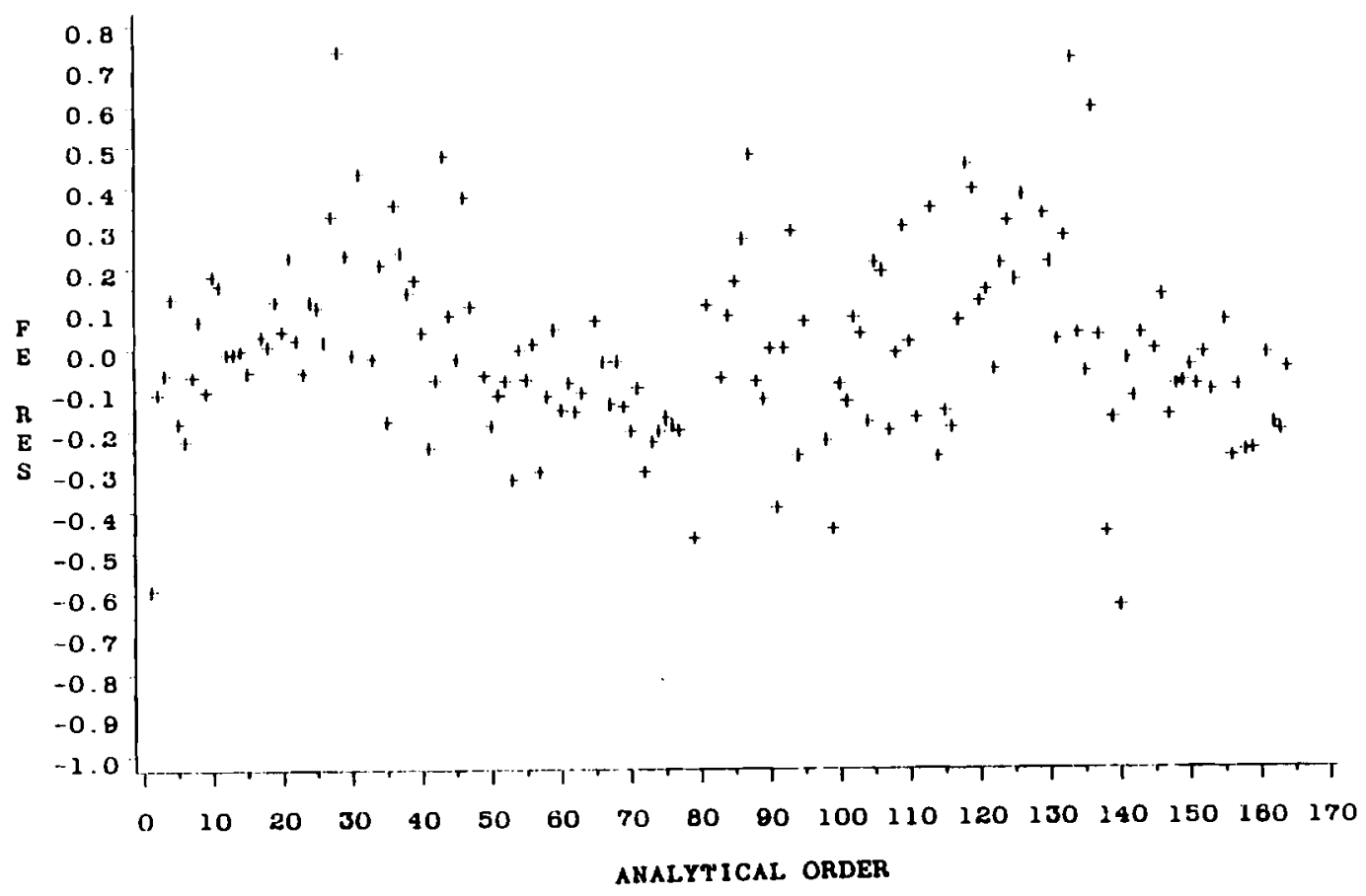

FIGURE B.11. Plot of Residuals Versus Analytical Order for Iron (Fe) Homogeneity and Sampling System Test with Reference Melter Feed Slurry.

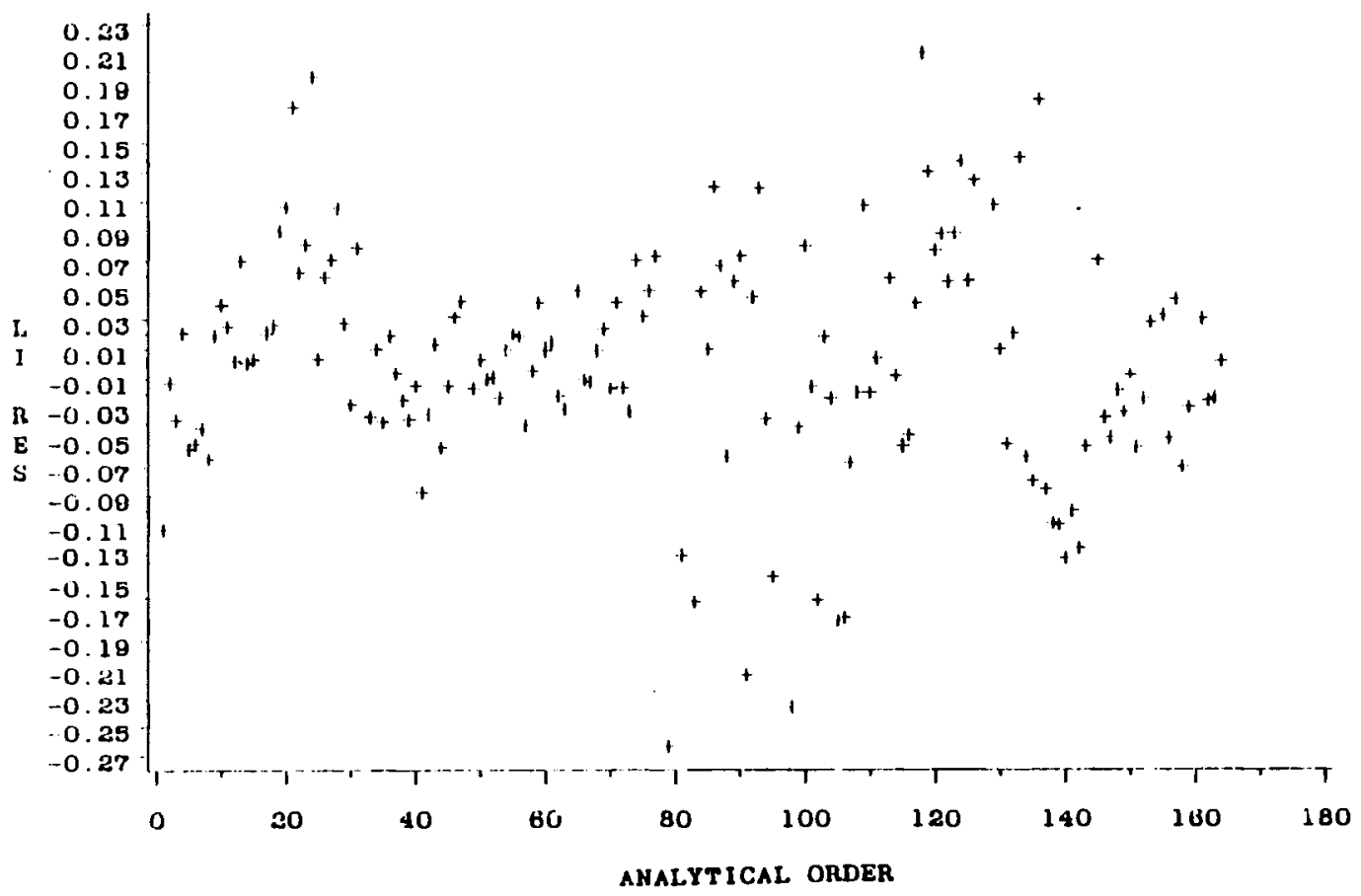

FIGURE B.12. Plot of Residuals Versus Analytical Order for Lithium (Li) Homogeneity and Sampling System Test with Reference Melter Feed Slurry. 


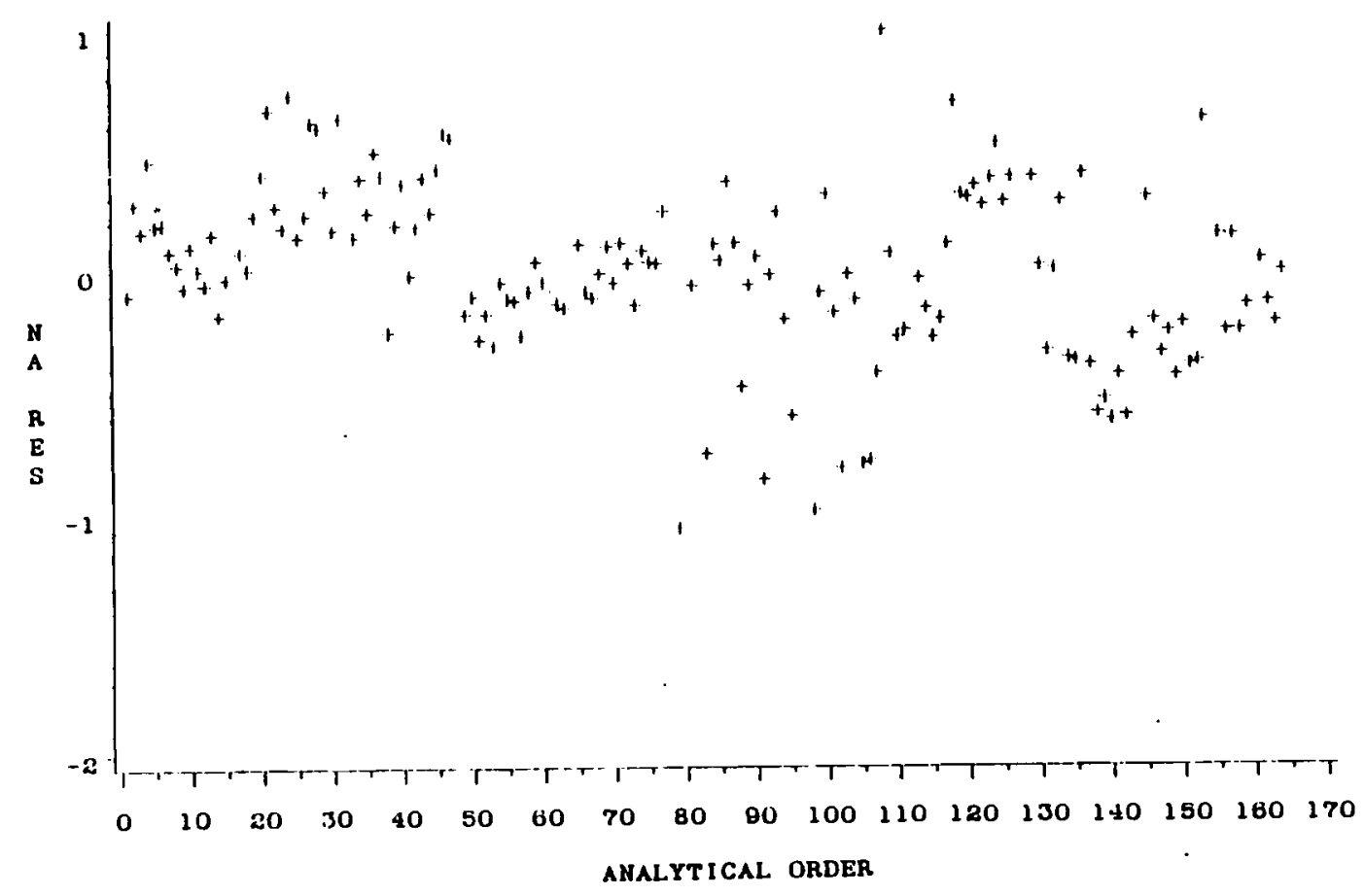

FIGURE B.13. Plot of Residuals Versus Analytical Order for Sodium (Na) Homogeneity and Sampling System Test with Reference Melter Feed Slurry.

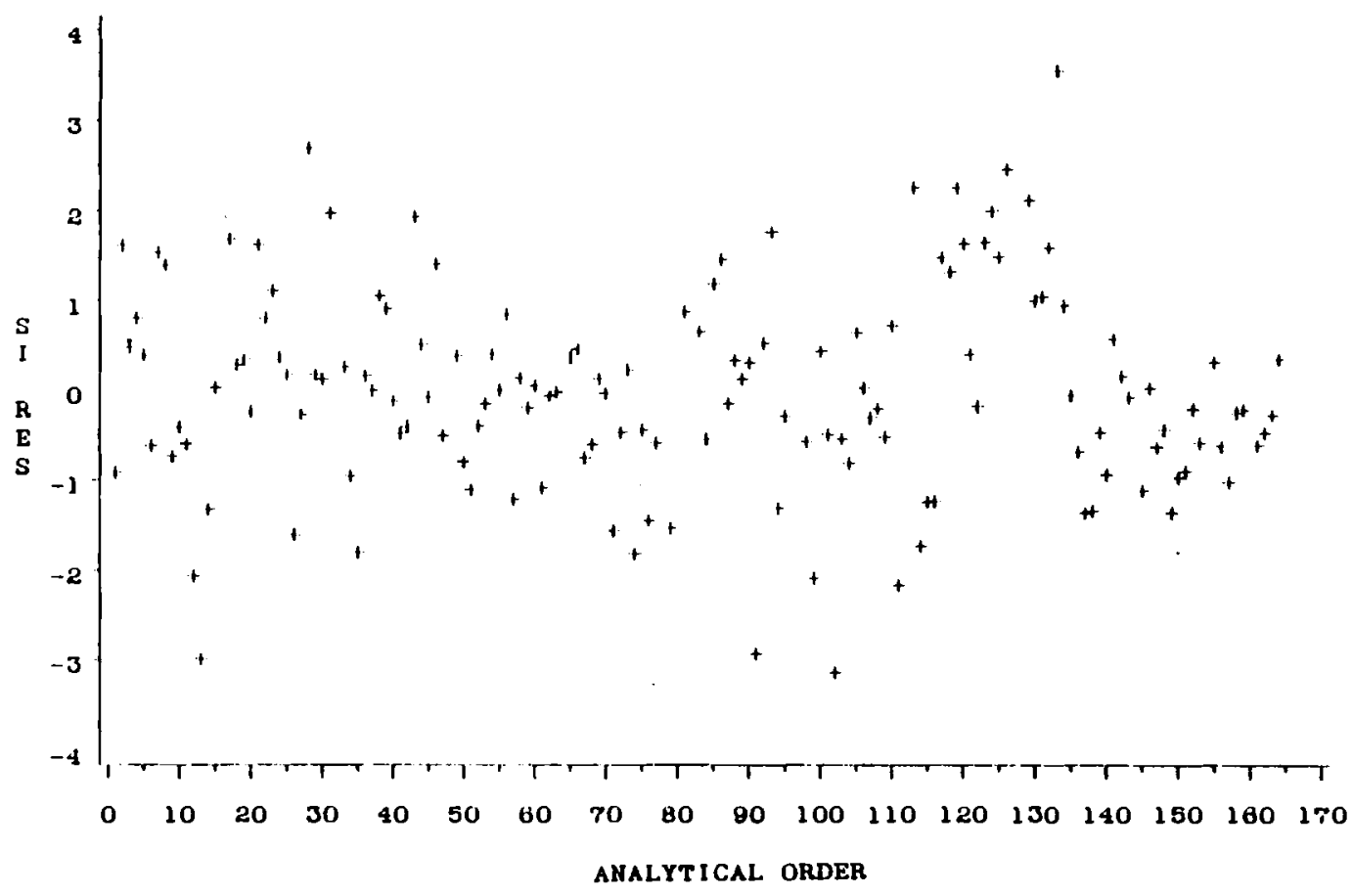

FIGURE B.14. Plot of Residuals Versus Analytical Order for Silica (Si) Homogeneity and Sampling System Test with Reference Melter Feed Slurry. 


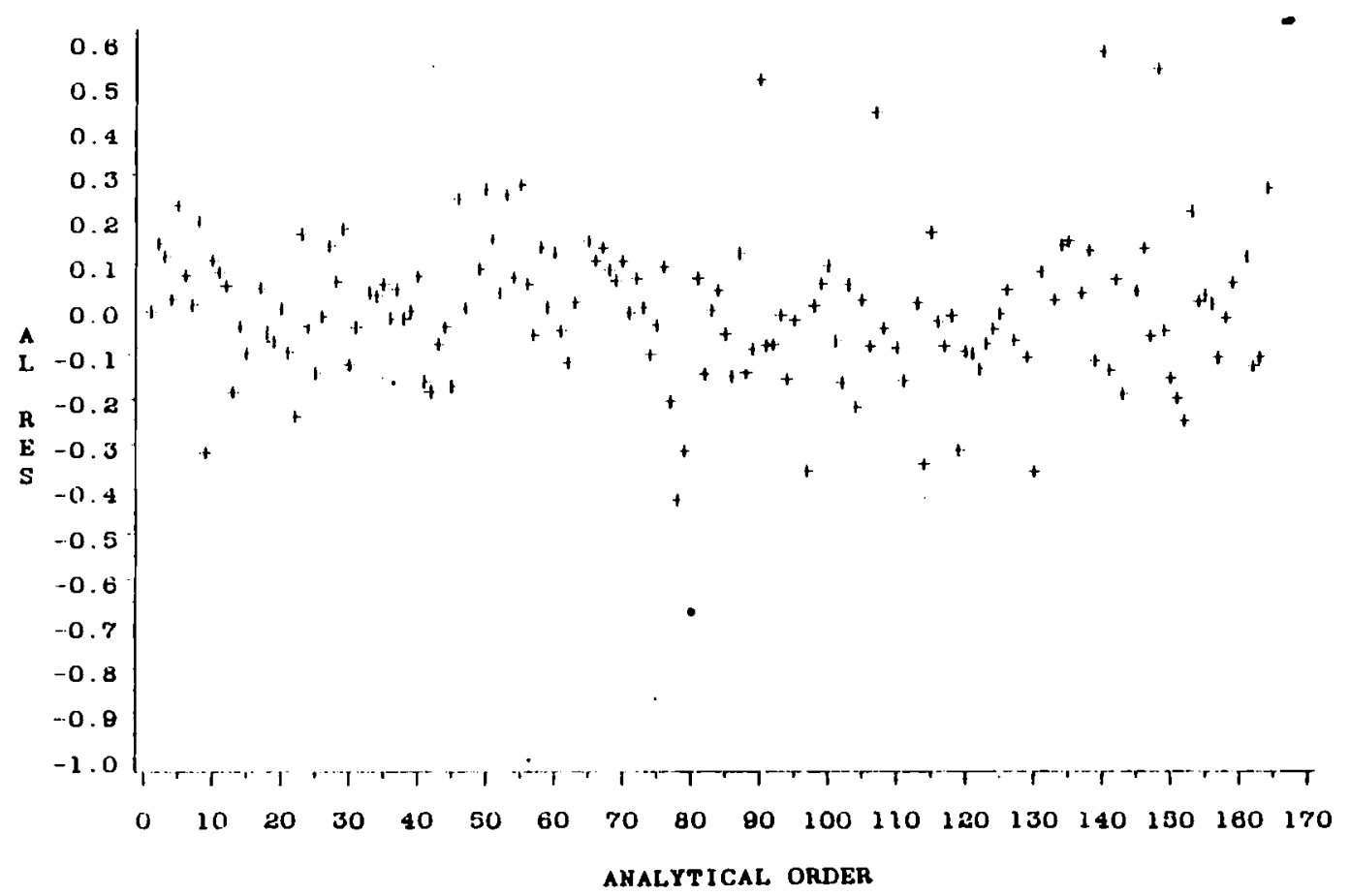

FIGURE B.15. Plot of Residuals Versus Analytical Order for Aluminum (A1) Homogeneity and Sampling System Test with Dilute

Melter Feed Slurry.

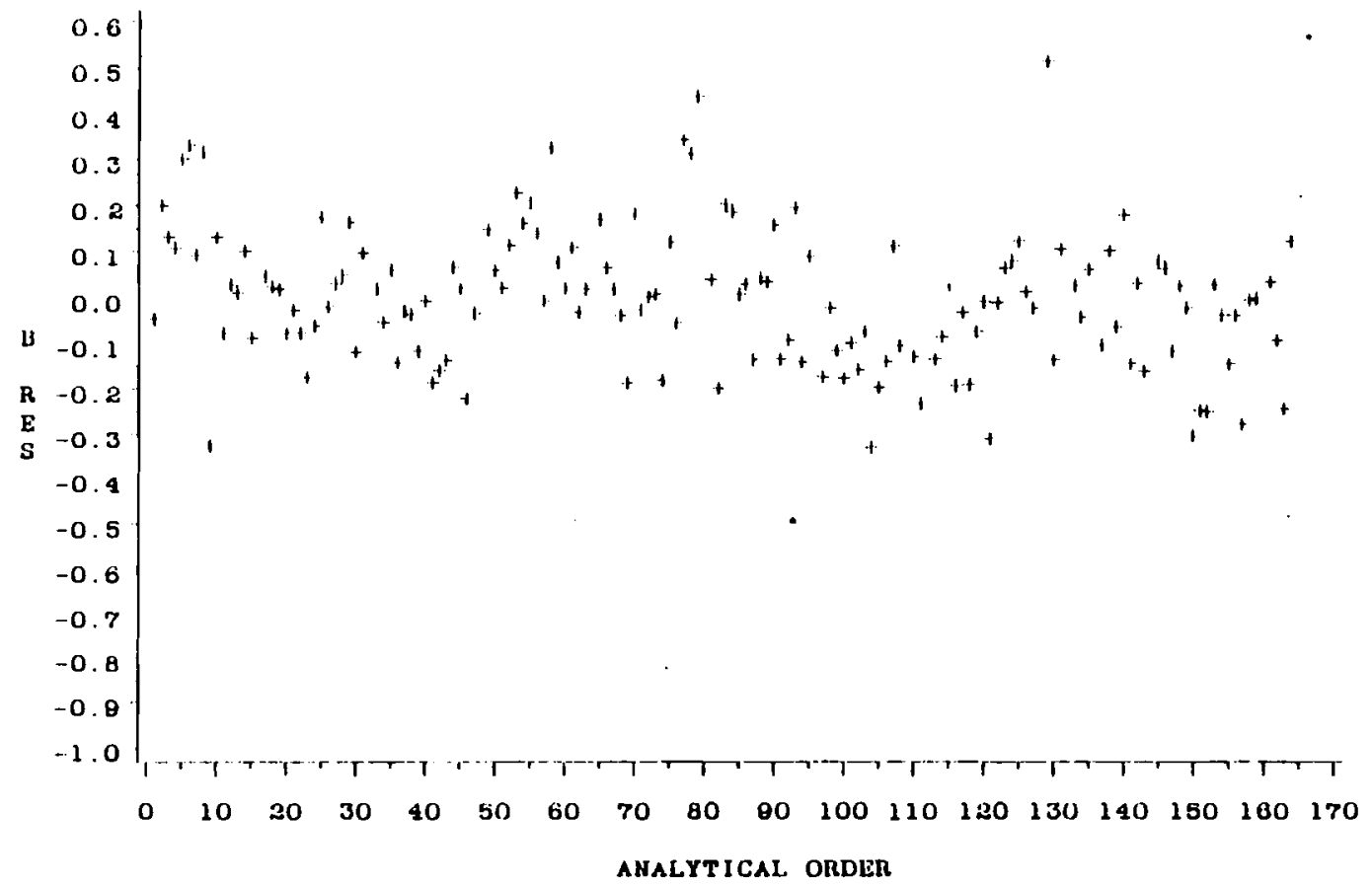

FIGURE B.16. Plot of Residuals Versus Analytical Order for Boron (B) Homogeneity and Sampling System Test with Dilute Melter Feed Slurry. 


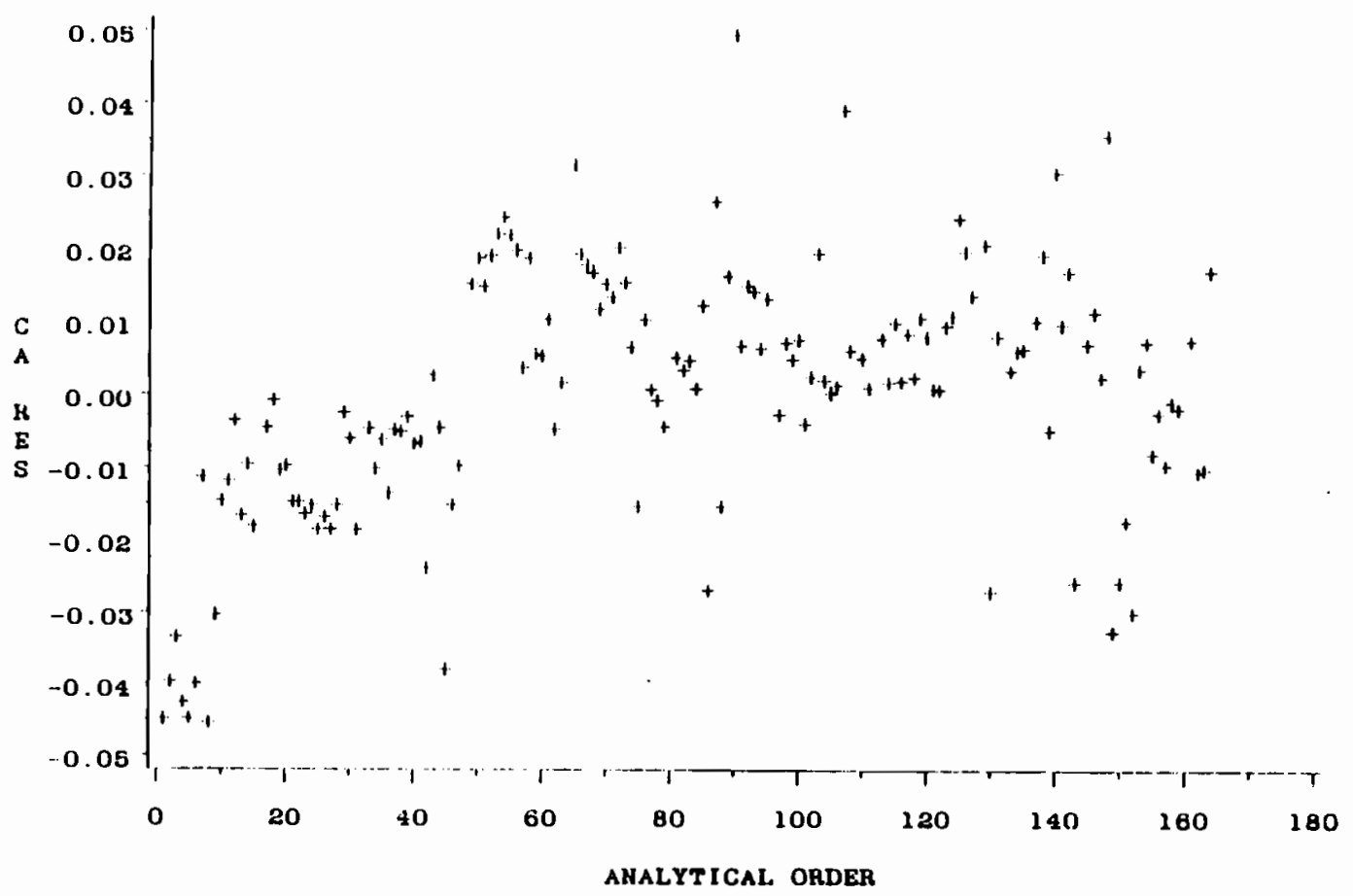

FIGURE B.17. Plot of Residuals Versus Analytical Order for Calcium (Ca) Homogeneity and Sampling System Test with Dilute Melter Feed Slurry.

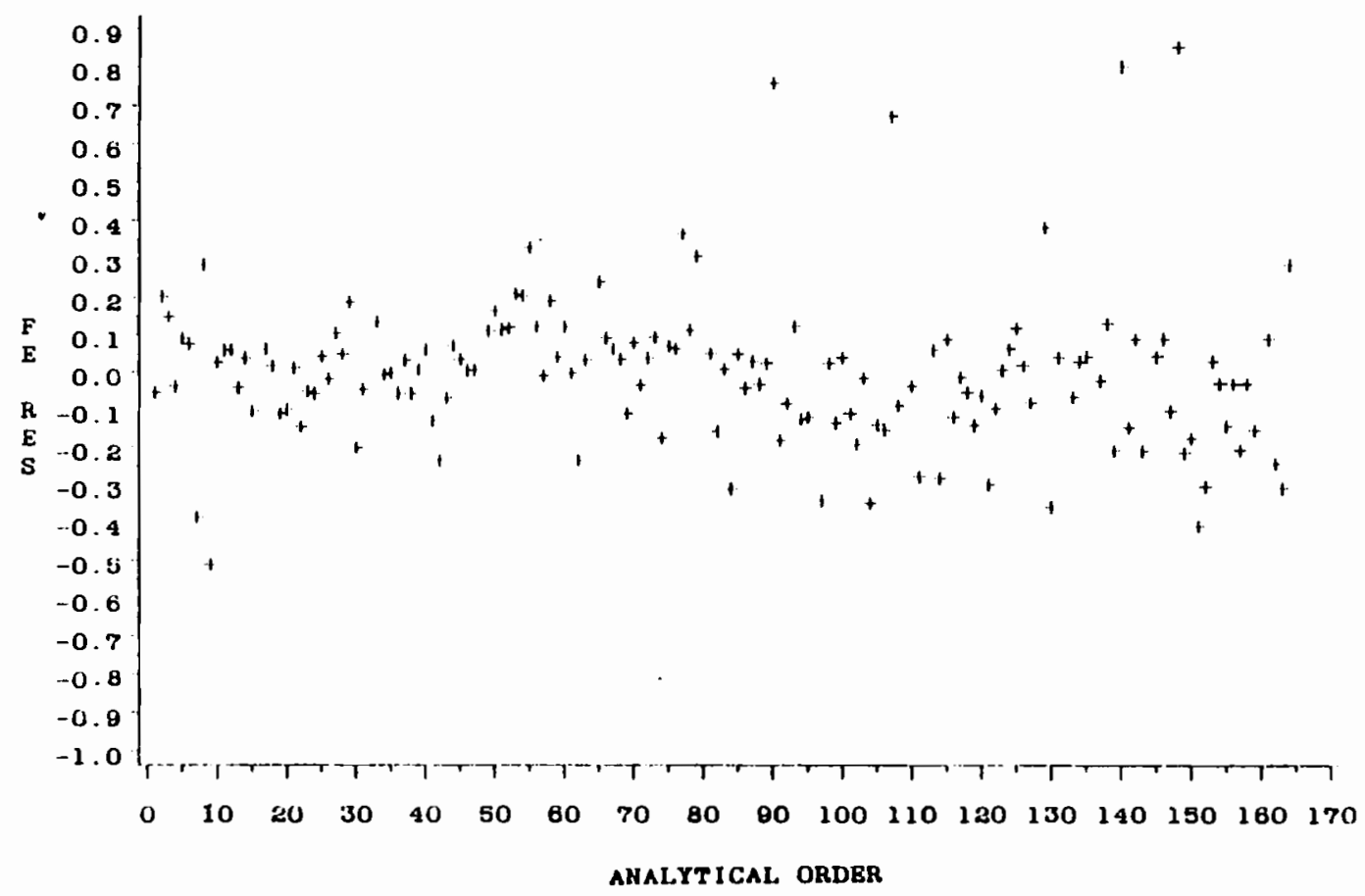

FIGURE B.18. Plot of Residuals Versus Analytical Order for Iron (Fe) Homogeneity and Sampling System Test with Dilute Melter Feed Slurry. 


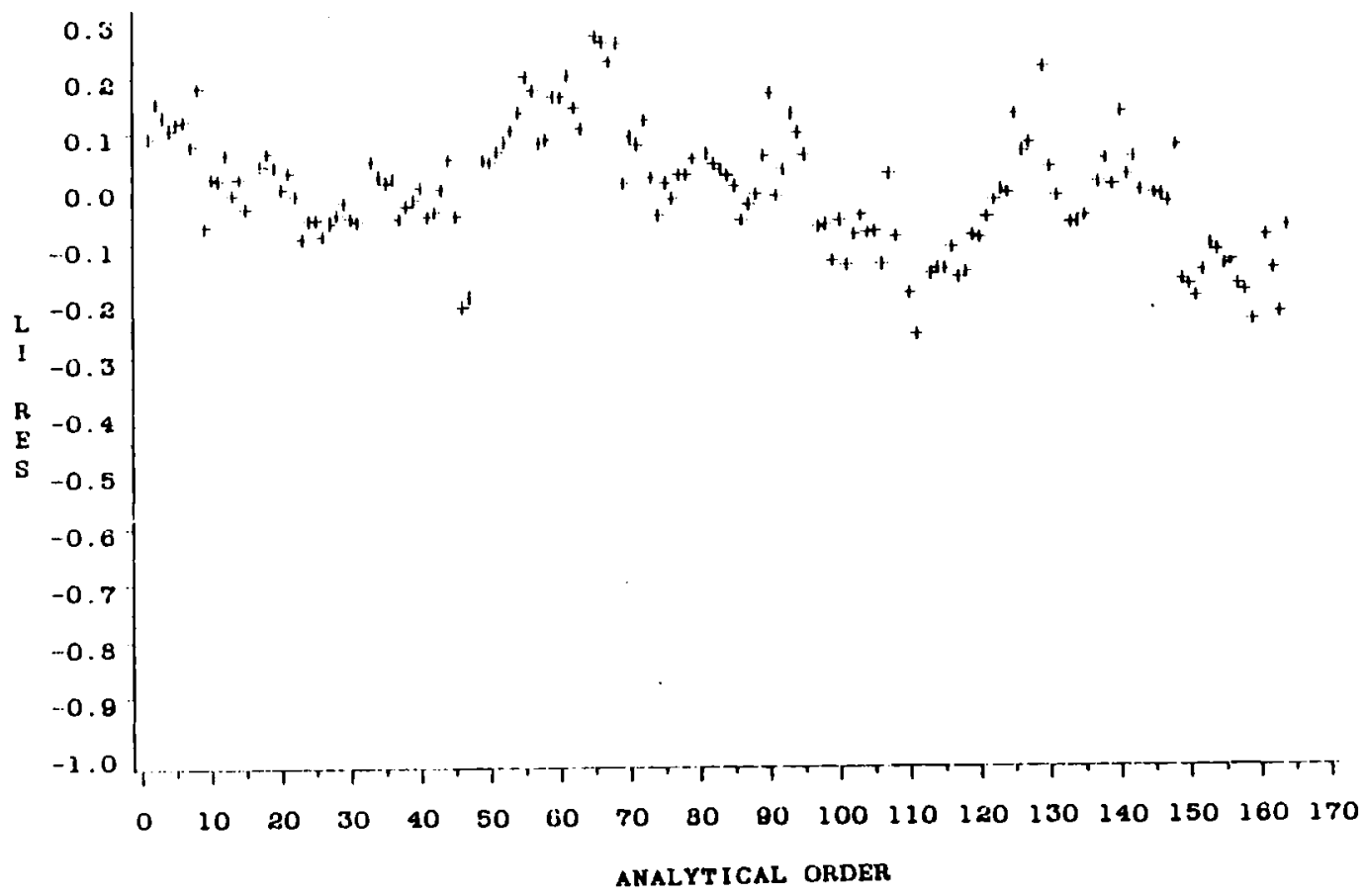

FIGURE B.19. Plot of Residuals Versus Analytical Order for Lithium (Li)Homogeneity and Sampling System Test with Dilute Melter Feed Slurry.

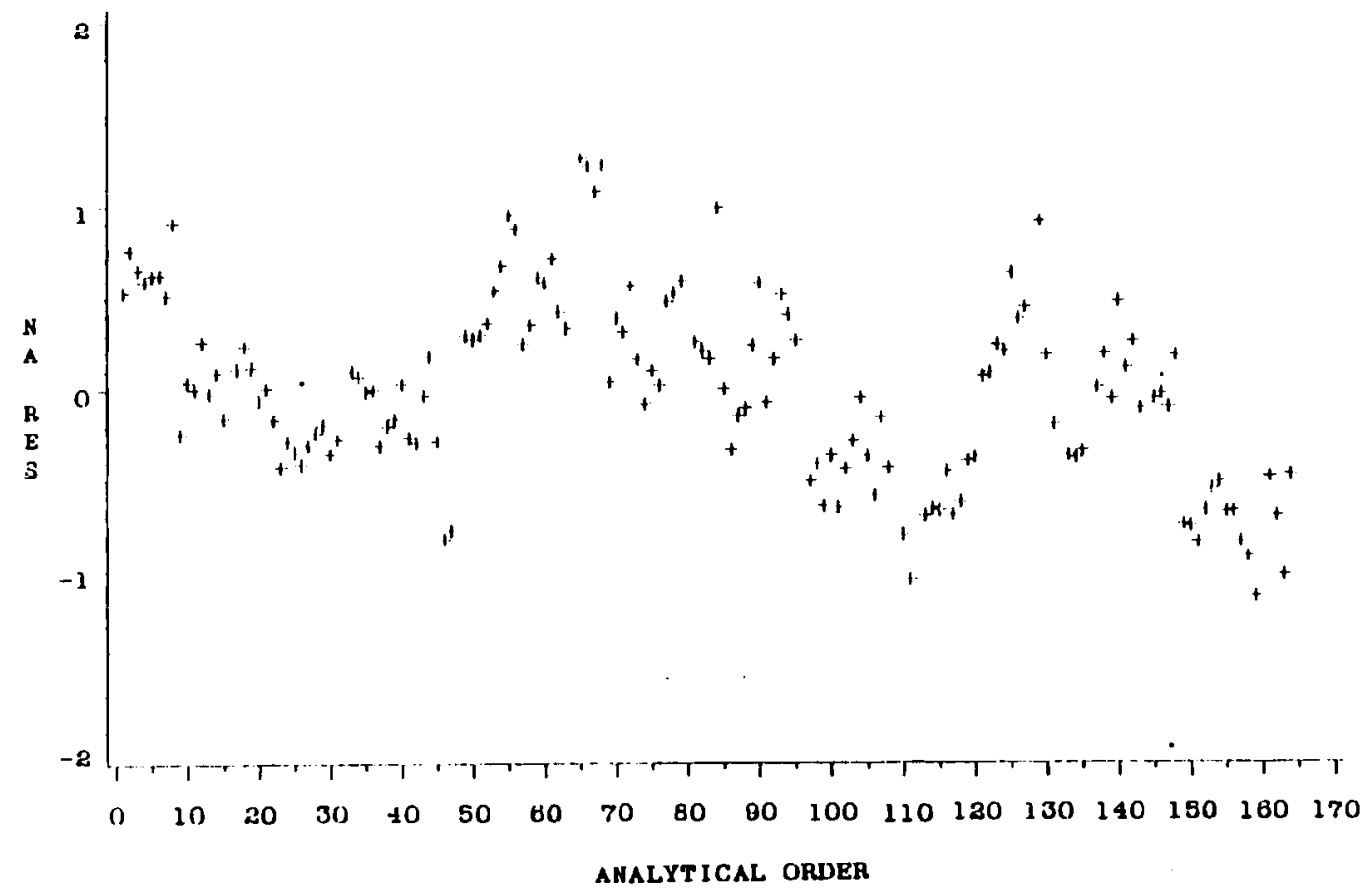

FIGURE B.20. Plot of Residuals Versus Analytical Order for Sodium (Na) Homogeneity and Sampling System Test with Dilute Melter Feed Slurry. 


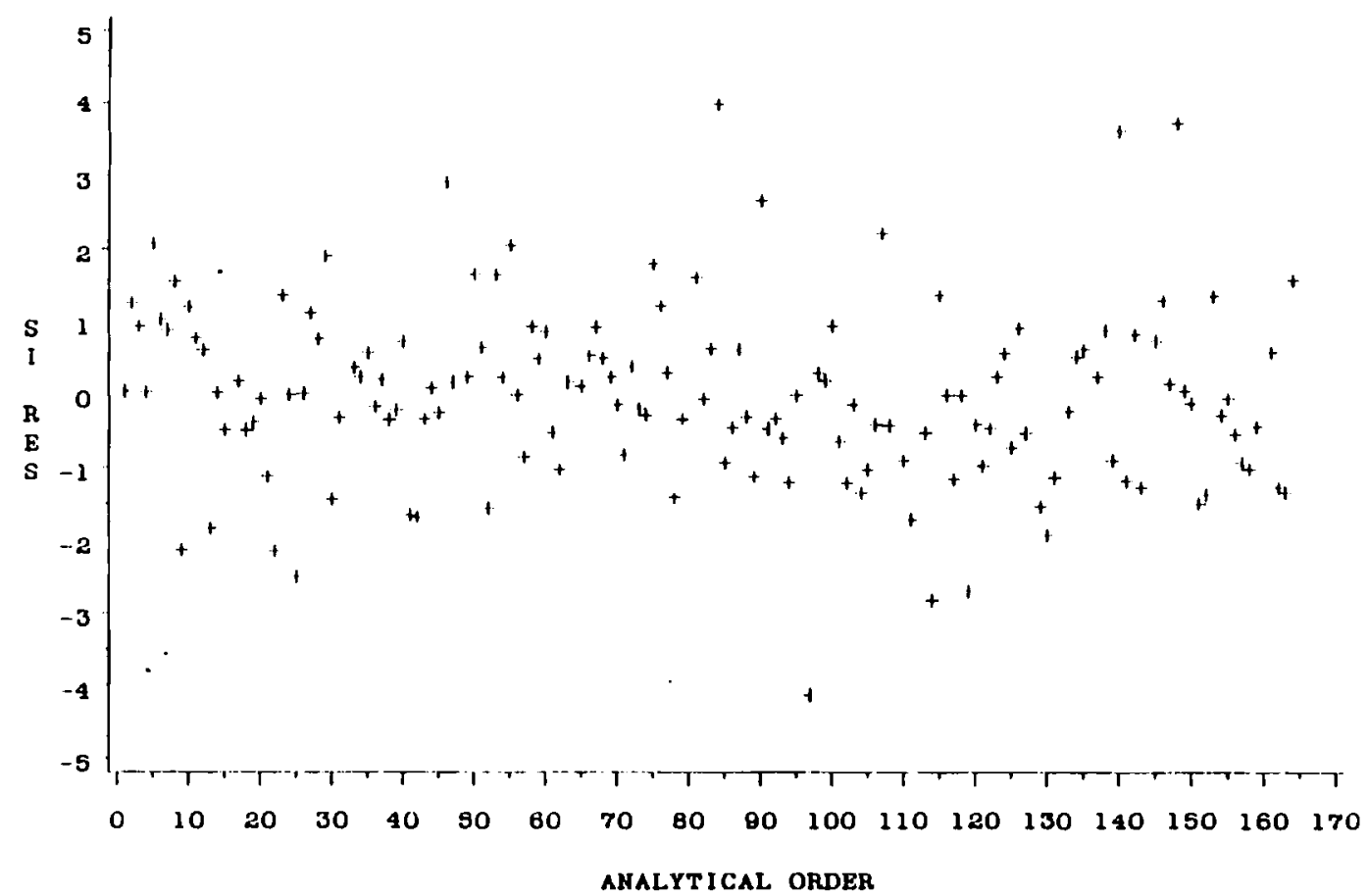

FIGURE B.21. Plot of Residuals Versus Analytical Order for Silica (Si) Homogeneity and Sampling System Test with Dilute

Melter Feed Slurry.

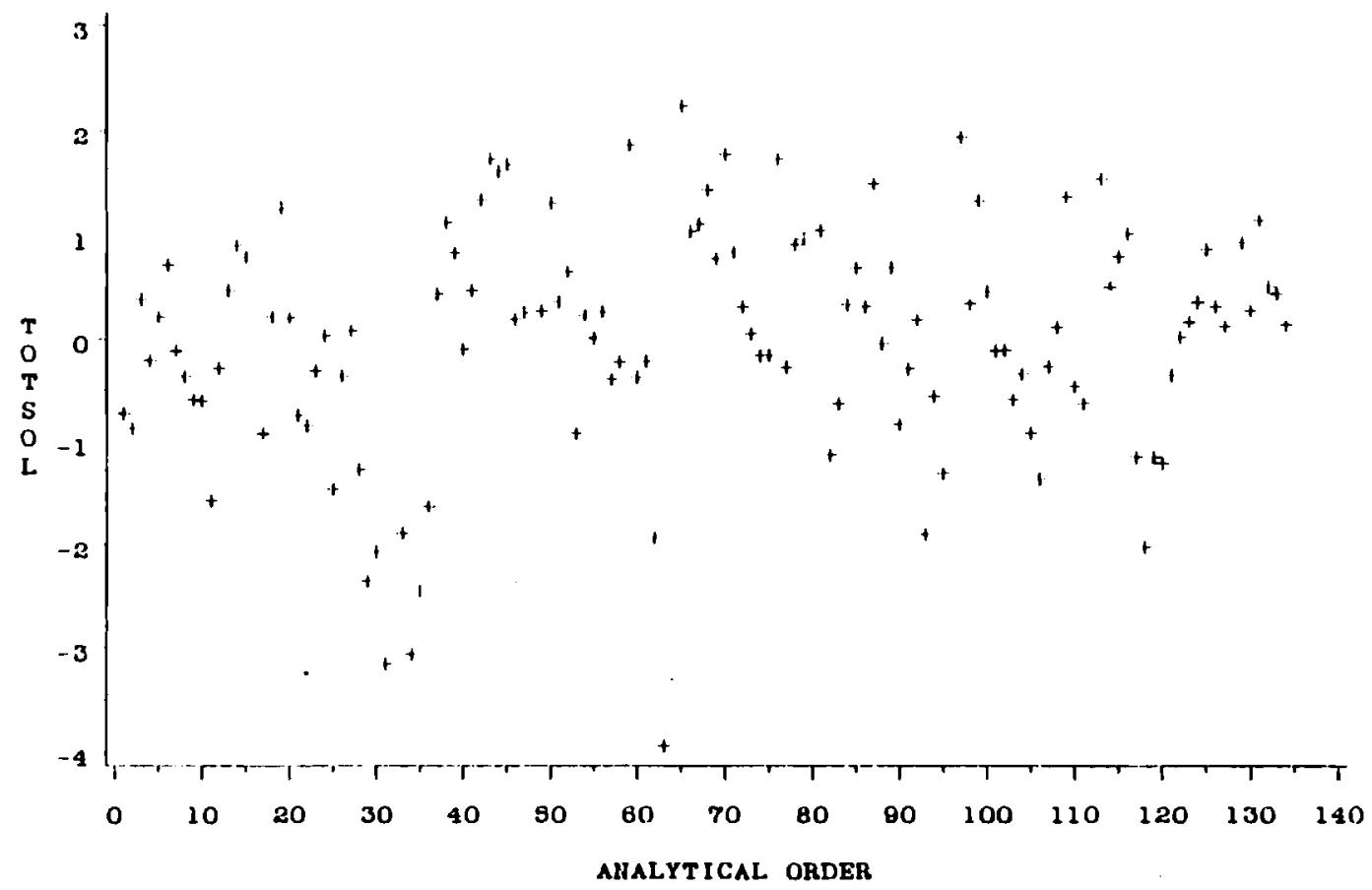

FIGURE B.22. Plot of Residuals Versus Analytical Order for Total Solids Resuspension Test with Concentrated Melter Feed Slurry. 


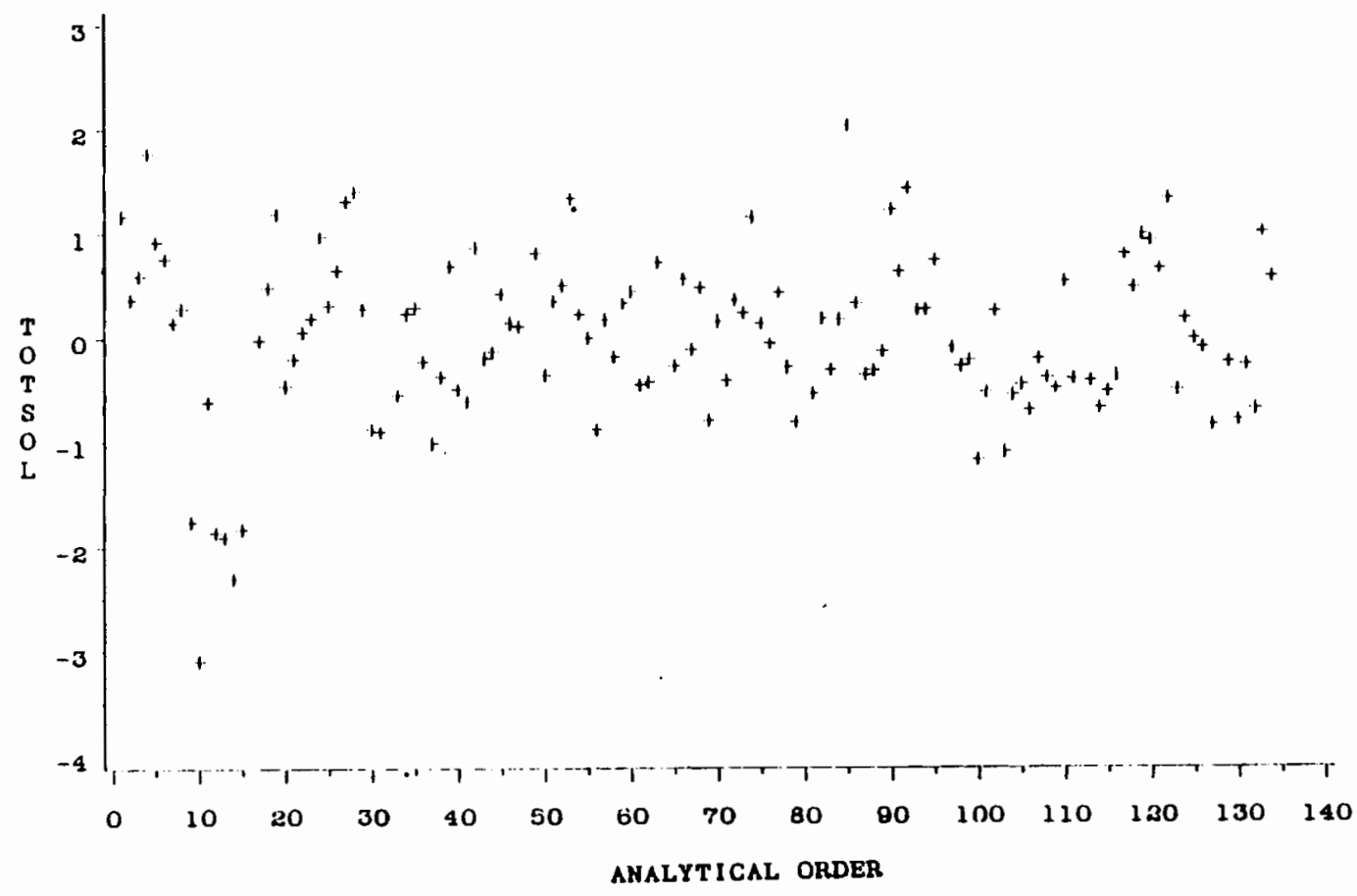

FIGURE B.23. Plot of Residuals Versus Analytical Order for Total Solids Resuspension Test with Reference Melter Feed Slurry.

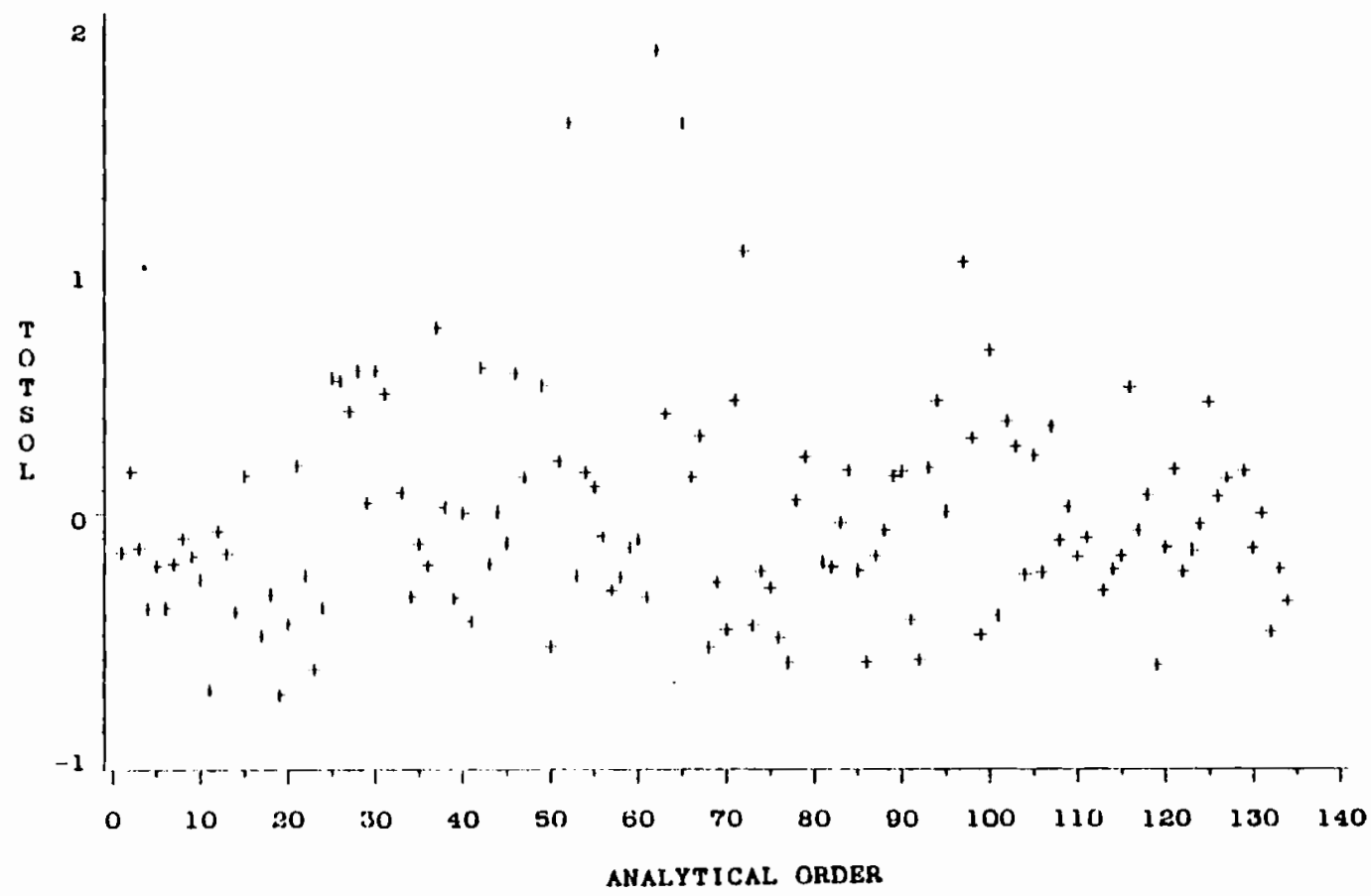

FIGURE B.24. Plot of Residuals Versus Analytical Order for Total Solids Resuspension Test with Dilute Melter Feed Slurry. 


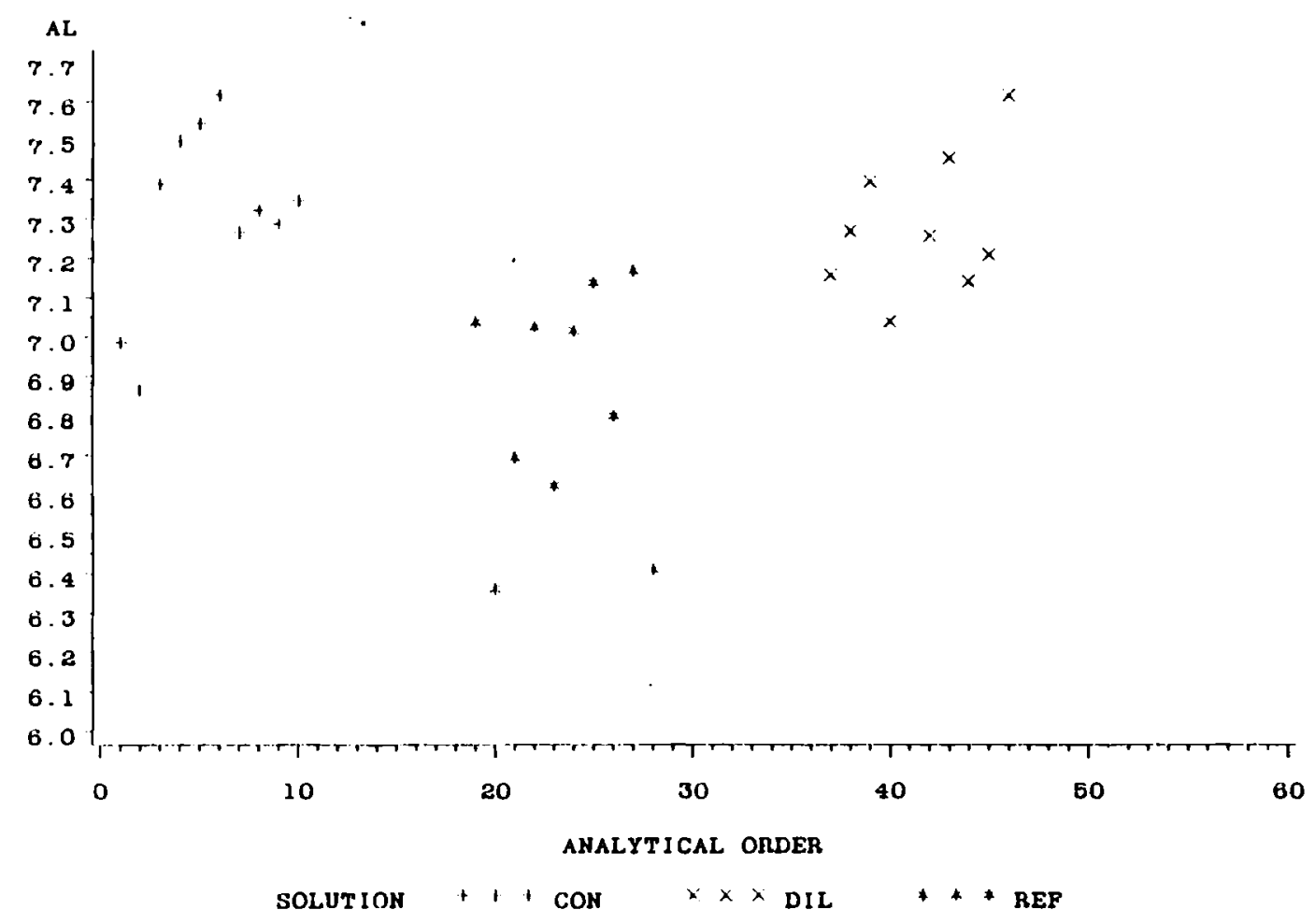

FIGURE B.25. Plot of Normalized Weight Percent Aluminum (Al) Versus Analytical Order for the Control Samples

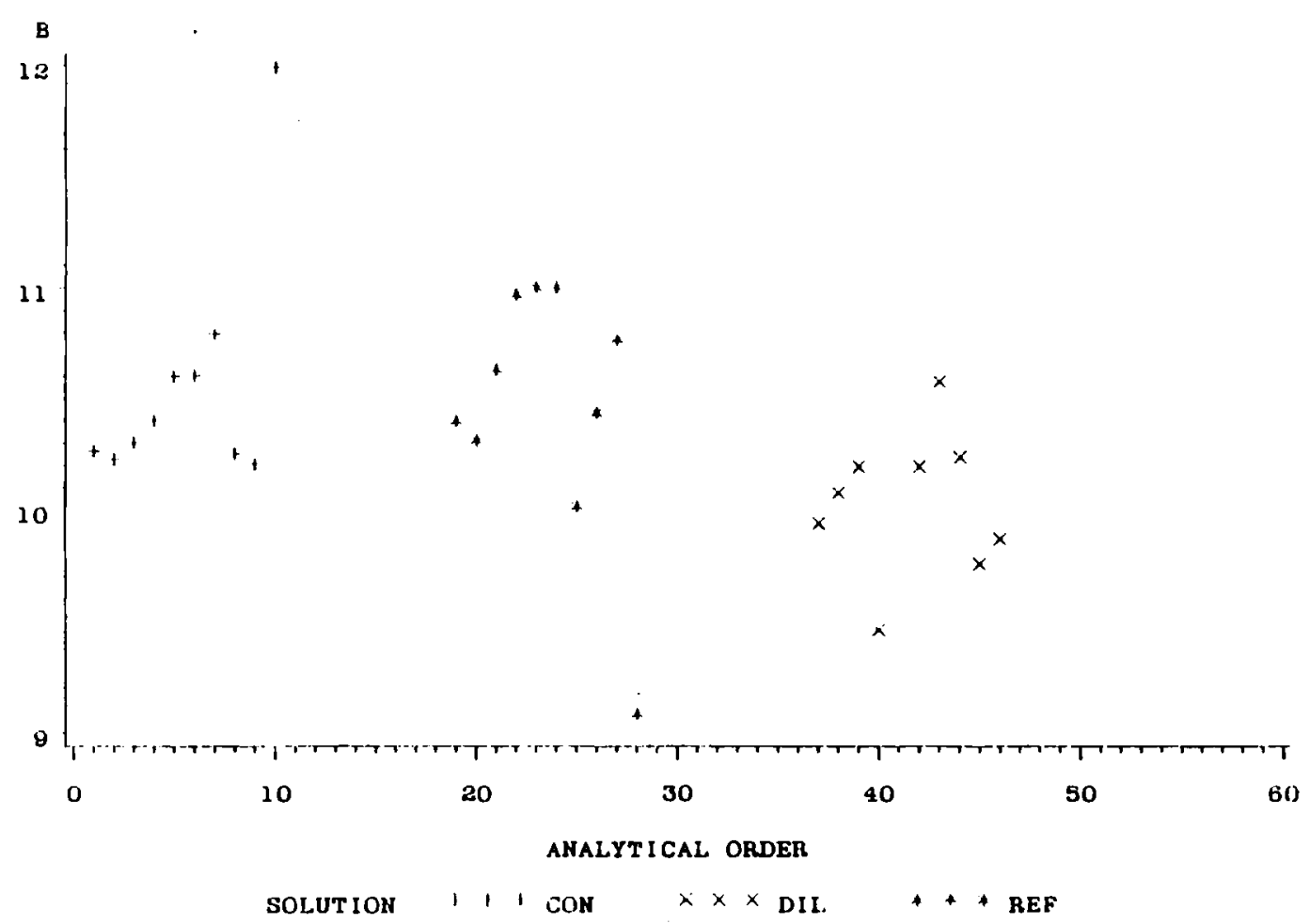

FIGURE B.26. Plot of Normalized Weight Percent Boron (B) Versus Analytical Order for the Control Samples 


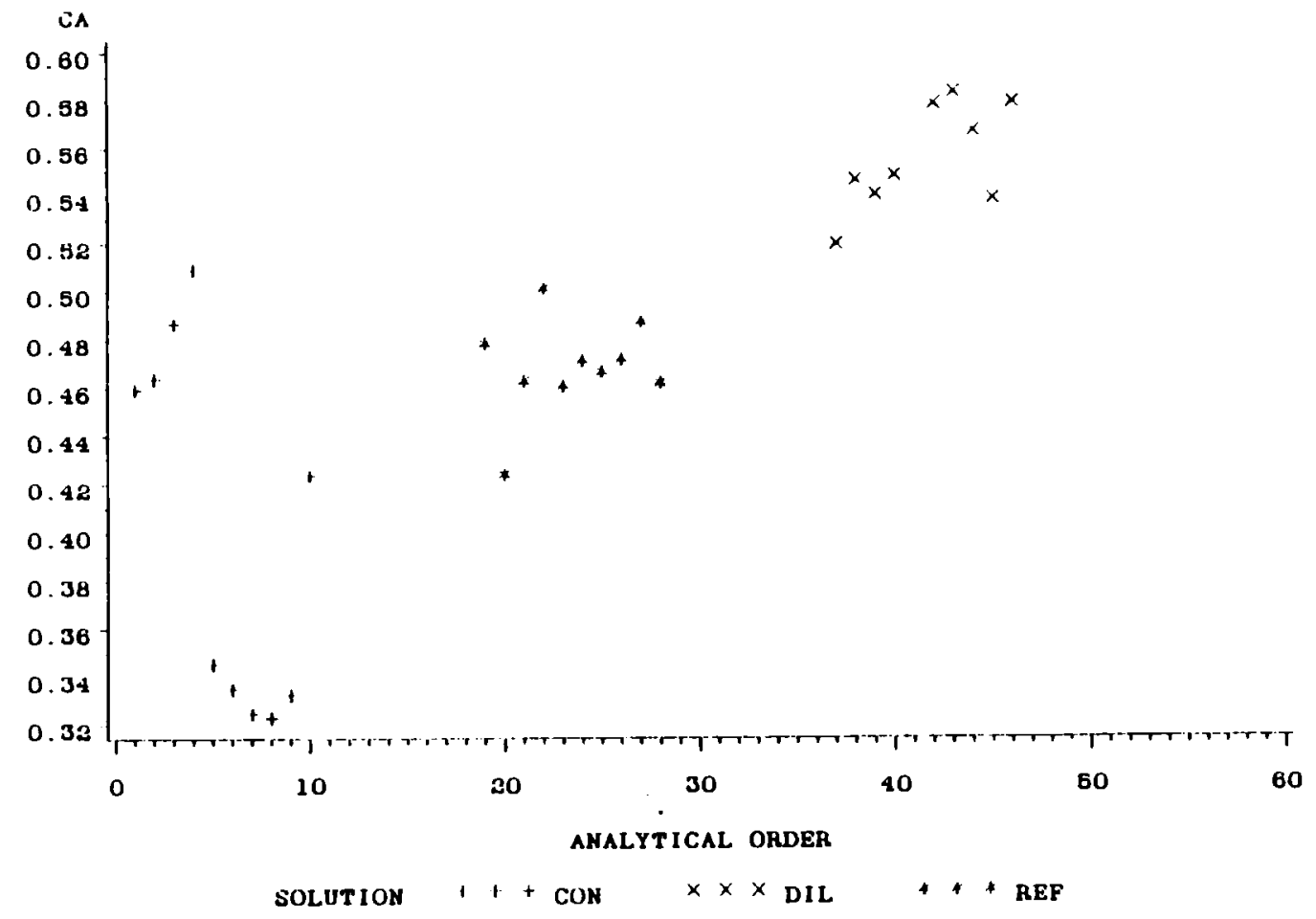

FIGURE B.27. Plot of Normalized Weight Percent Calcium (Ca) Versus Analytical Order for the Control Samples

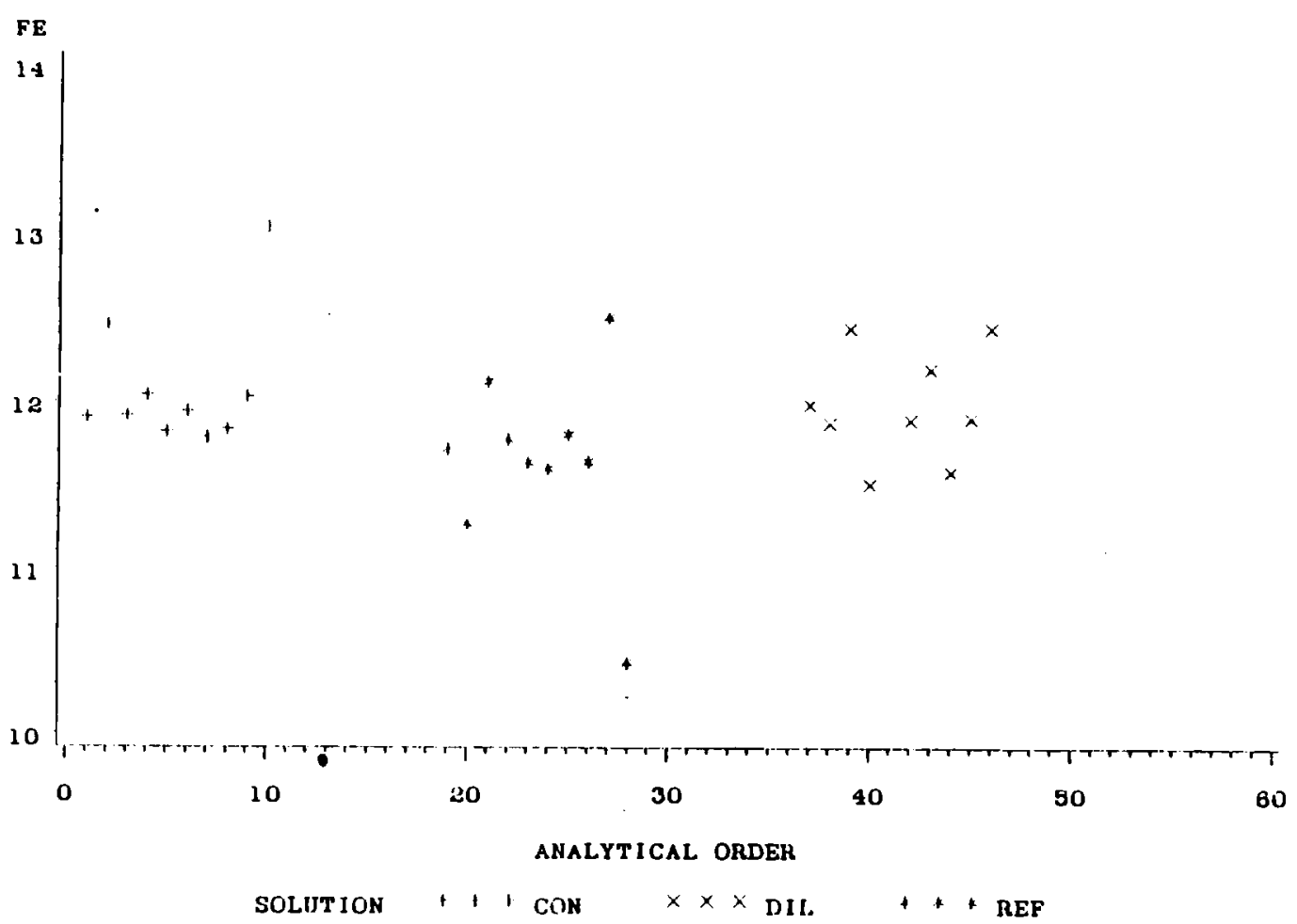

FIGURE B.28. Plot of Normalized Weight Percent Iron (Fe) Versus Analytical Order for the Control Samples 


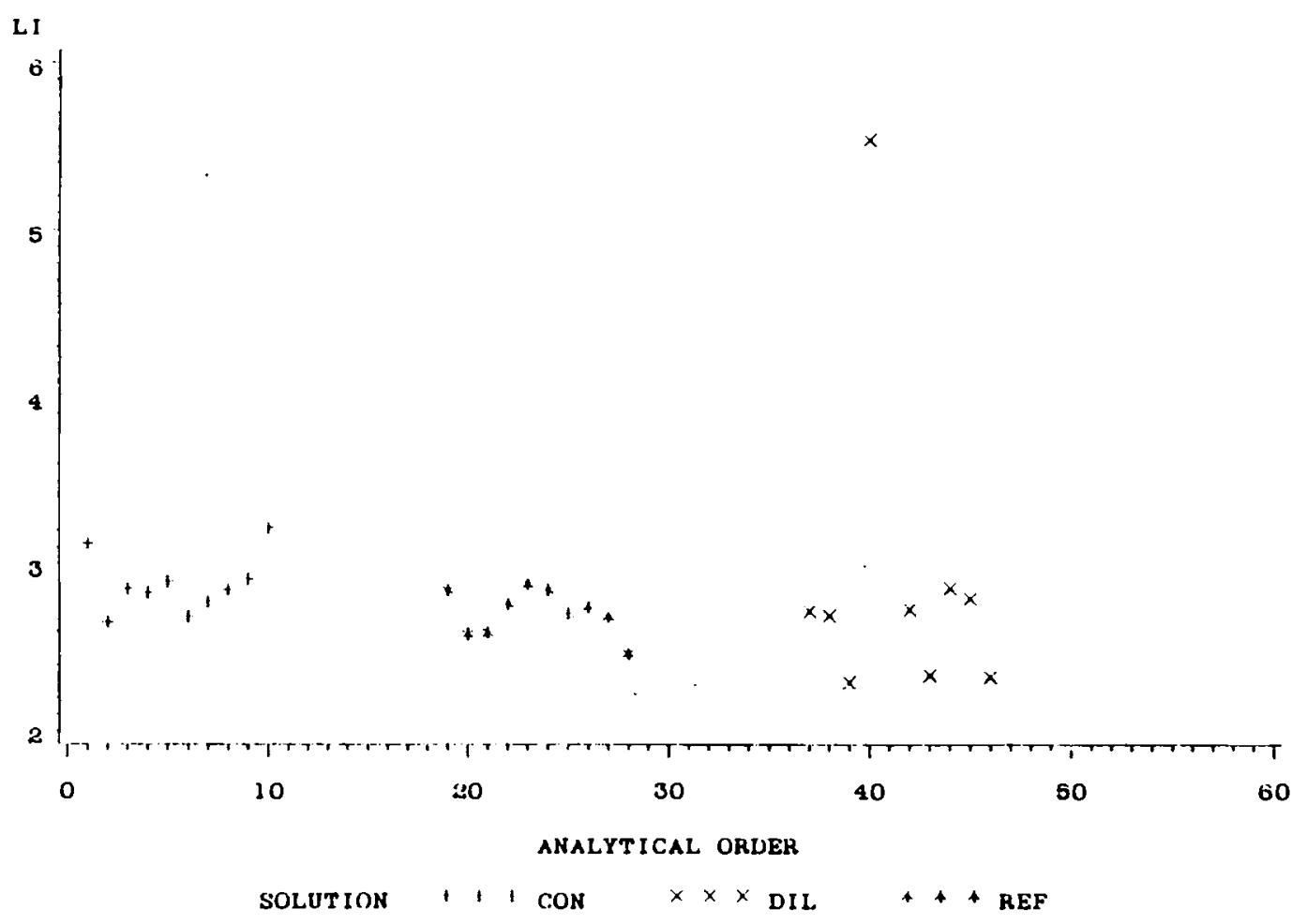

FIGURE B.29. Plot of Normalized Weight Percent Lithium (Li) Versus Analytical Order for the Control Samples

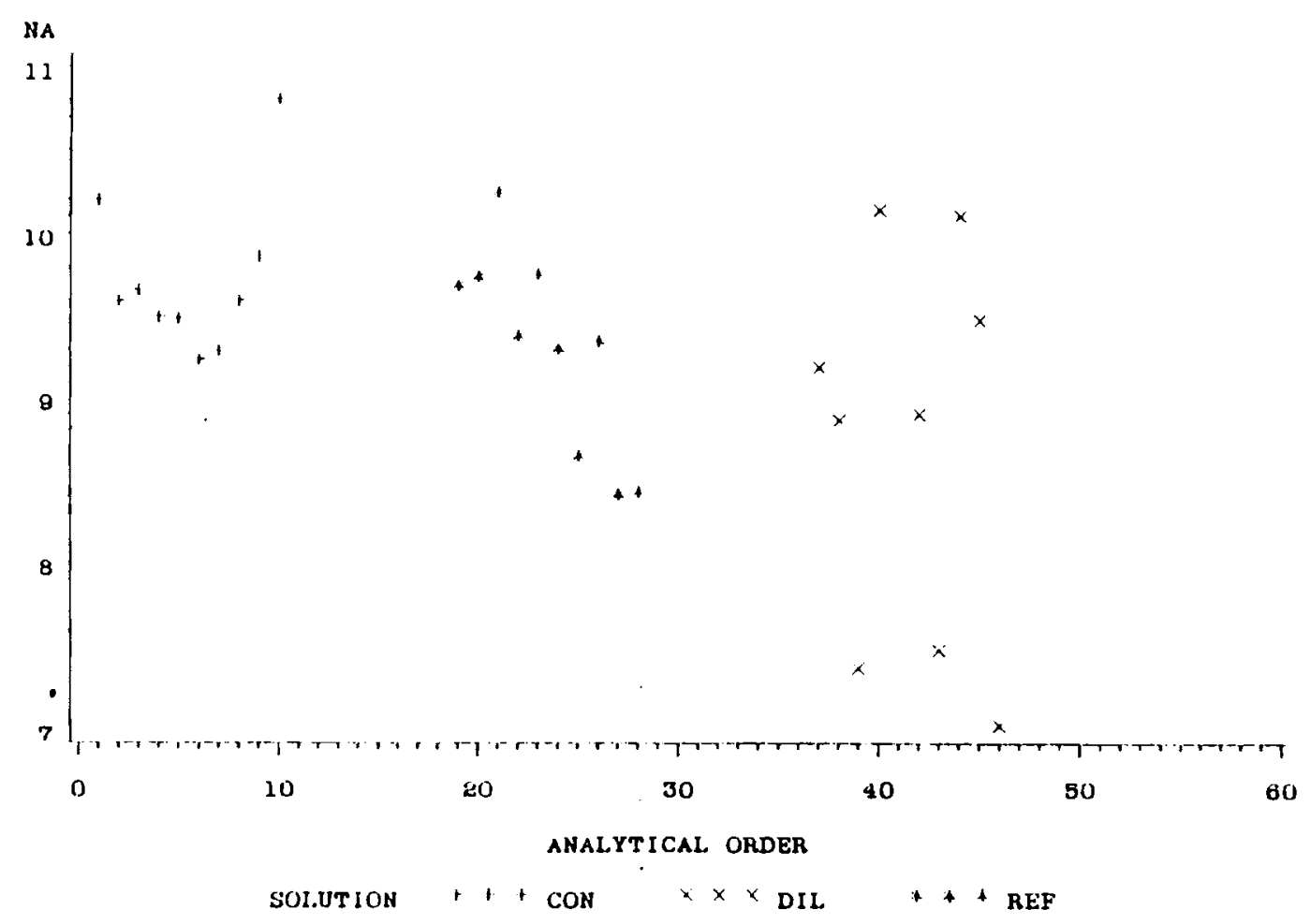

FIGURE B.30. Plot of Normalized Weight Percent Sodium (Na) Versus Analytical Order for the Control Samples

B. 16 


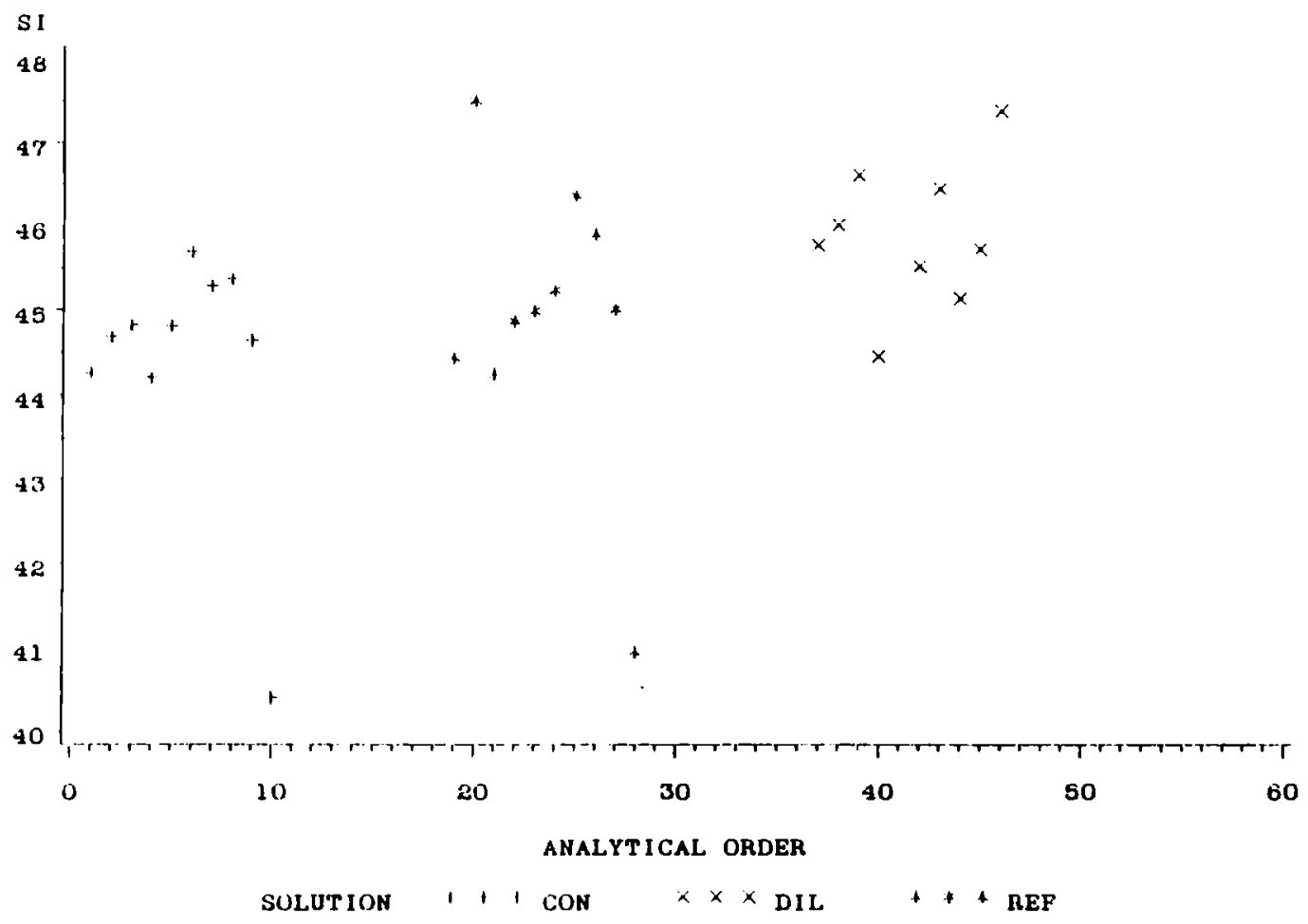

FIGURE B.31. Plot of Normalized Weight Percent Silica (Si) Versus Analytical Order for the Control Samples 


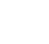

. 


\section{DISTRIBUTION}

No. of

Copies

\section{$\underline{\text { OFFSITE }}$}

10 DOE/Office of Scientific and Technical Information

4 DOE Office of Civilian Radioactive Waste Management Forrestal Building Washington, DC 20585

ATTN: L. H. Barrett, RW-33

S. H. Kale, RW-20

D. E. Shelor, RW-32

R. Stein, RW-23

2 DOE Office of Defense Waste \& GTN

Transportation Management

Washington, DC 20545

ATTN: K. A. Chacey, DP-123

T. B. Hindman, DP-12

4 DOE Office of Remedial Action GTN

Washington, DC 20545

ATTN: J. E. Baublitz, NE-20

J. A. Coleman, NE-24

T. W. McIntosh, NE-24

H. F. Walter, NE-24

A. T. Clark

Division of Fuel Material Safety Nuclear Regulatory Commission Washington, DC 20555

V. Stello

office for the Executive

Director for Operations

Mail Station 6209

Nuclear Regulatory Commission Washington, DC 20555
No. of

Copies

S. Meyers

Environmental Protection Agency

Office of Radiation Programs (ANR-458)

401 M Street S.W.

Washington, DC 20460

J. M. McGough

DOE Albuquerque Operations Office

P.0. Box 5400

Albuquerque, NM 87185

P. G. Hagan

Joint Integration office

Carlmont Executive 1

4308 Carlisle N.E.

Suite 101

Albuquerque, NM 87107

E. Maestas

DOE West Valley Project

P.0. Box 191

West Valley, NY 14171

3 DOE Idaho Operations Office

550 Second Street

Idaho Falls, ID 83401

ATTN: M. W. Shupe

J. P. Hamric

C. R. Enos

F. T. Fong

DOE San Francisco Operations

1333 Broadway

0akl and, CA 94612

M. R. Jugan

DOE Oak Ridge Operations Office

P.0. Box E

Oak Ridge, TN 37830

W. T. Goldston

DOE Savannah River Operations Office

P.0. Box A

Aiken, SC 29801 
No. of

Copies

M. J. Steindler

Argonne National Laboratory 9700 South Cass Avenue

Argonne, IL 60439

C. S. Abrams

Argonne National Laboratory

P.0. Box 2528

Idaho Falls, ID 83401

3 Battelle Memorial Institute

Project Management Division

505 King Avenue

Columbus, $\mathrm{OH} 43201$

ATTN: W. A. Carbeiner

R. A. Nathan

Technical Library

L. D. Ramspott

Lawrence Livermore National Laboratory

University of California

P.0. Box 808

Livermore, CA 94550

D. T. Oakley, MS 619

Los Al amos Scientific Laboratory P.0. Box 1663

Los Alamos, NM 87544

$4 \quad$ Oak Ridge National Laboratory

P.O. Box $Y$

Oak Ridge, TN 37830

ATTN: W. D. Burch

R. T. Jubin

L. J. Mezga

D. W. Turner

2 Sandia Laboratories

P.0. Box 5800

Albuquerque, NM 87185

ATTN: R. W. Lynch

Technical Library
No. of

Copies

J. R. Berreth

Westinghouse Idaho Nuclear

Co., Inc.

P.0. Box 4000

Idaho Falls, ID 83401

6 E. I. du Pont de Nemours Company

Savannah River Laboratory

Aiken, SC 29801

ATTN: R. G. Baxter

M. D. Boersma

J. G. Glasscock

J. R. Knight

M. J. Plodinec

C. T. Randall

A. D. Rodgers

Mail Stop 2411

EG\&G Idaho

P.0. Box 1625

Idaho Falls, ID 83415

R. Shaw

Electric Power Research Institute

3412 Hillview Avenue

P.0. Box 10412

Palo Alto, CA 94303

7 West Valley Nuclear Services Company

P.0. Box 191

West Valley, NY 14171

ATTN: S. M. Barnes

B. P. Bauer

R. R. Borisch

R. A. Humphrey

J. M. Pope

K. A. O-Ahoofe

R. A. Thomas

J. L. White, Chairman

Energy Research \& Development Authority

Empire State Plaza

Albany, NY 12223 
No. of

Copies

\section{ONSITE}

6 DOE Richland Operations office
R. W. Brown
C. E. Collantes
M. J. Furman
R. E. Gerton
P. E. Lamont
E. C. Norman

27 Pacific Northwest Laboratory
C. R. Allen
W. W. Ballard, Jr.
H. C. Burkholder
C. C. Chapman

No. of

Copies

Pacific Northwest Laboratory (contd)

C. L. Fow

W. 0 . Heath

W. L. Kuhn

D. E. Kurath (5)

J. L. McEl roy

J. M. Perez

M. E. Peterson

B. A. Pulsipher (2)

W. A. Ross

P. A. Scott

J. M. Seay

J. H. Westsik, Jr.

Publishing Coordination

Technical Report Files (5) 